\title{
HydroGeologic Assessment of the East Bear Creek Unit, San Luis National Wildlife Refuge
}

\section{Prepared for : US Bureau of Reclamation}

Nigel W.T. Quinn PhD, P.E.

Berkeley National Laboratory

1 Cyclotron Road, Bld,. 70A-3317H

Berkeley, CA 94720

July 15,2007 


\section{ACKNOWLEDGEMENTS}

This report was prepared for the US Bureau of Reclamation to assist the agency make planning decisions with respect to groundwater conjunctive use planning for the East Bear Creek Unit of the San Luis National Wildlife Refuge. The author gratefully acknowledges the financial support provided by Dan Meier, MP-410, US Bureau of Reclamation who initiated the project and to staff at the San Luis National Wildlife Refuge for well log data. Dr Grace Su and Paul Cook (Lawrence Berkeley National Laboratory) assisted with the groundwater water quality logging and geophysical logging in the East Bear Creek Unit. Tony Shanahan (US Bureau of Reclamation) operated the Geoprobe which was used to make the geophysical logs and bulk salinity depth profiles that were interpreted by Jeff Farrar at the Technical Services Center (US Bureau of Reclamation) and are included in this report. Steve Sherer (US Bureau of Reclamation) provided useful data, reports and analysis that were used in the preparation of this report. Dr Kenneth Schmidt (Kenneth Schmidt and Associates) provided invaluable access to reports and data as well as advice based on his many years of groundwater consulting in the Valley. Thanks to Dr. Grace Su, Dr. Kenneth Schmidt, Dan Meier and Georgiana Gregory (US Bureau of Reclamation) for their review and helpful comments on the report. 


\section{TABLE OF CONTENTS}

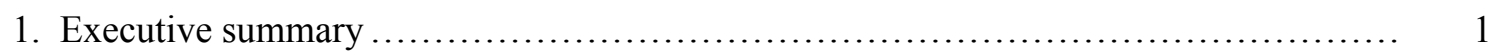

2. HydroGeological assessment

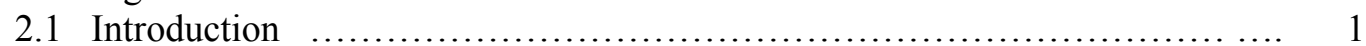

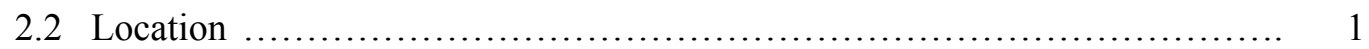

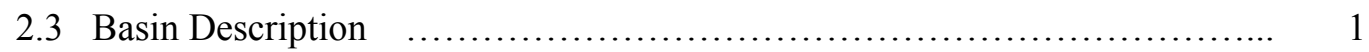

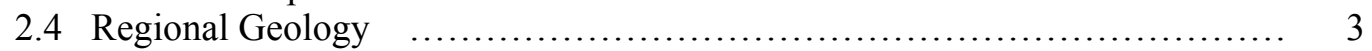

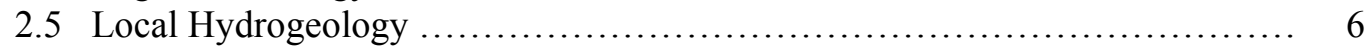

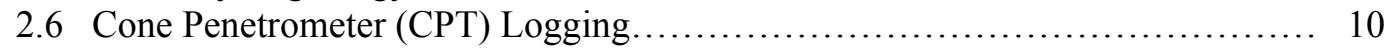

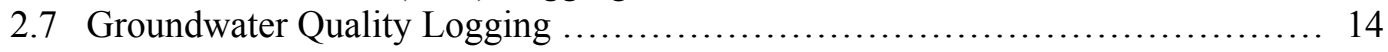

2.7.1 Fluid electrical conductivity logging in limited access wells ......... 22

2.7.2 Open, abandoned well EB-01................................. 22

2.8 Groundwater Quality................................................... 24

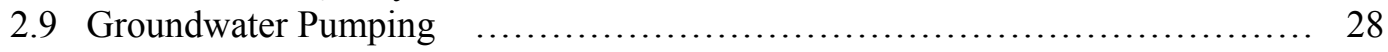

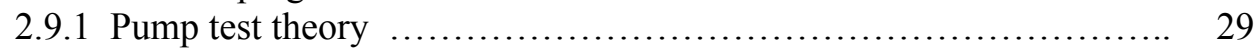

2.9.1.1 Theis Method ........................................ 30

2.9.1.2 Cooper and Jacob Method .............................. 31

2.9.1.3 Neuman Method ......................................... 32

2.9.1.4 Moench Method ......................................... 33

2.10 Groundwater Resource Evaluation................................... 34

2.11 Groundwater Levels and Aquifer Safe Yield............................ 35

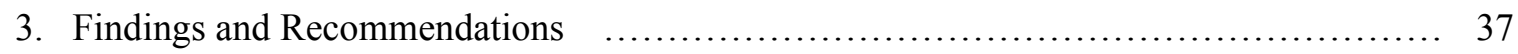

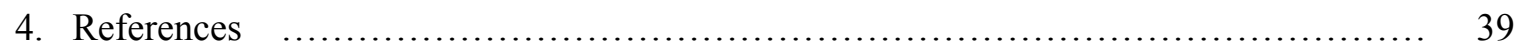

5. Appendices

Appendix A : Pumping test results from test wells in East Bear Creek Unit ............. 41

Appendix B : Geologic Logs from test holes .................................... 50

Appendix C : East Bear Creek Refuge Water Supply .............................. 64 


\section{EXECUTIVE SUMMARY}

The East Bear Creek Unit is currently being evaluated as a potential source of supplemental water supply for the San Luis National Wildlife Refuge Complex to meet Reclamation's obligations for Level 4 water supply under the Central Valley Project Improvement Act. Hydrogeological assessment of the East Bear Creek Unit of the San Luis National Wildlife Refuge was conducted using a combination of field investigations and a survey of available literature from past US Geological Survey Reports and reports by local geological consultants. Conservative safe yield estimates made using the available data show that the East Bear Creek Unit may have sufficient groundwater resources in the shallow groundwater aquifer to meet about between $25 \%$ and $52 \%$ of its current Level II and between $17 \%$ and $35 \%$ of its level IV water supply needs. The rate of surface and lateral recharge to the Unit and the design of the well field and the layout and capacity of pumped wells will decide both the percentage of annual needs that the shallow aquifer can supply and whether this yield is sustainable without affecting long-term aquifer quality. In order to further investigate the merits of pumping the near surface aquifer, which appears to have reasonable water quality for use within the East Bear Creek Unit - monitoring of the potential sources of aquifer recharge and the installation of a pilot shallow well would be warranted. Simple monitoring stations could be installed both upstream and downstream of both the San Joaquin River and Bear Creek and be instrumented to measure river stage, flow and electrical conductivity. Ideally this would be done in conjunction with a shallow pilot well, pumped to supply a portion of the Unit's needs for the wetland inundation period.

\section{HYDROGEOLOGICAL ASSESSMENT}

\subsection{Introduction}

The goal of this hydrogeological report is to provide an assessment of the groundwater resource conditions within the East Bear Creek Unit of the San Luis National Wildlife Refuge (NWR) Complex in western Merced County. The US Department of Interior purchased the 4,000 acres that comprise the property in 1993 from the Gallo family for the purpose of meeting wildlife habitat needs. Potential refuge water supply sources include a combination of onsite and offsite surface and groundwater resources. Three groundwater production wells existed at one time on the East Bear Creek Unit - these have all been abandoned. The purpose of this report is to report on the condition of these wells, evaluate water quality conditions that exist or may exist within the groundwater aquifer and to suggest options based on current analysis of data.

\subsection{Location}

The 4,000 acre East Bear Creek Unit of the San Luis NWR Complex is bounded by the San Joaquin River on its western and southern borders. Bear Creek/Bravel Slough from the northern boundary of the refuge. The refuge is contained within Township 8S-11E.

\subsection{Basin description and water resources}

The East Bear Creek Unit of the San Luis NWR Complex lies within the Merced Groundwater Basin of western Merced County southwest of the City of Merced and to the east of the San Joaquin River (Figure 1). The Merced Groundwater Basin is bounded by the Merced river on the north, the San Joaquin River to the west and the Chowchilla River to the south and contains over a great number of municipal, industrial, agricultural and domestic wells (Schmidt, 2005). The proximity of these watercourses suggests that shallow wells in this region will have an opportunity for recharge. Active production wells in the groundwater basin have been reported as having capacities ranging from 100 to 4,500 gallons per minute (DWR, 2003). The safe pumping yield of the aquifer beneath the East Bear Creek Unit will be addressed in a qualitative fashion in this report based on current data and limited aquifer testing that was performed as part of this project. The location of the East-Bear Creek Unit adjacent to the San Joaquin River Basin 
trough and its position at the distal end of the east-side Merced River alluvial fan (Figure 2) would suggest that limitations for groundwater conjunctive use are more likely to be water quality related given the interfingering of alluvial clays, derived from the west-side of the Basin in this subarea. These clay lenses reduce connectivity between shallow and deep subsurface aquifers and can hinder drainage allowing evaporative concentration of salts in the near-surface aquifer.

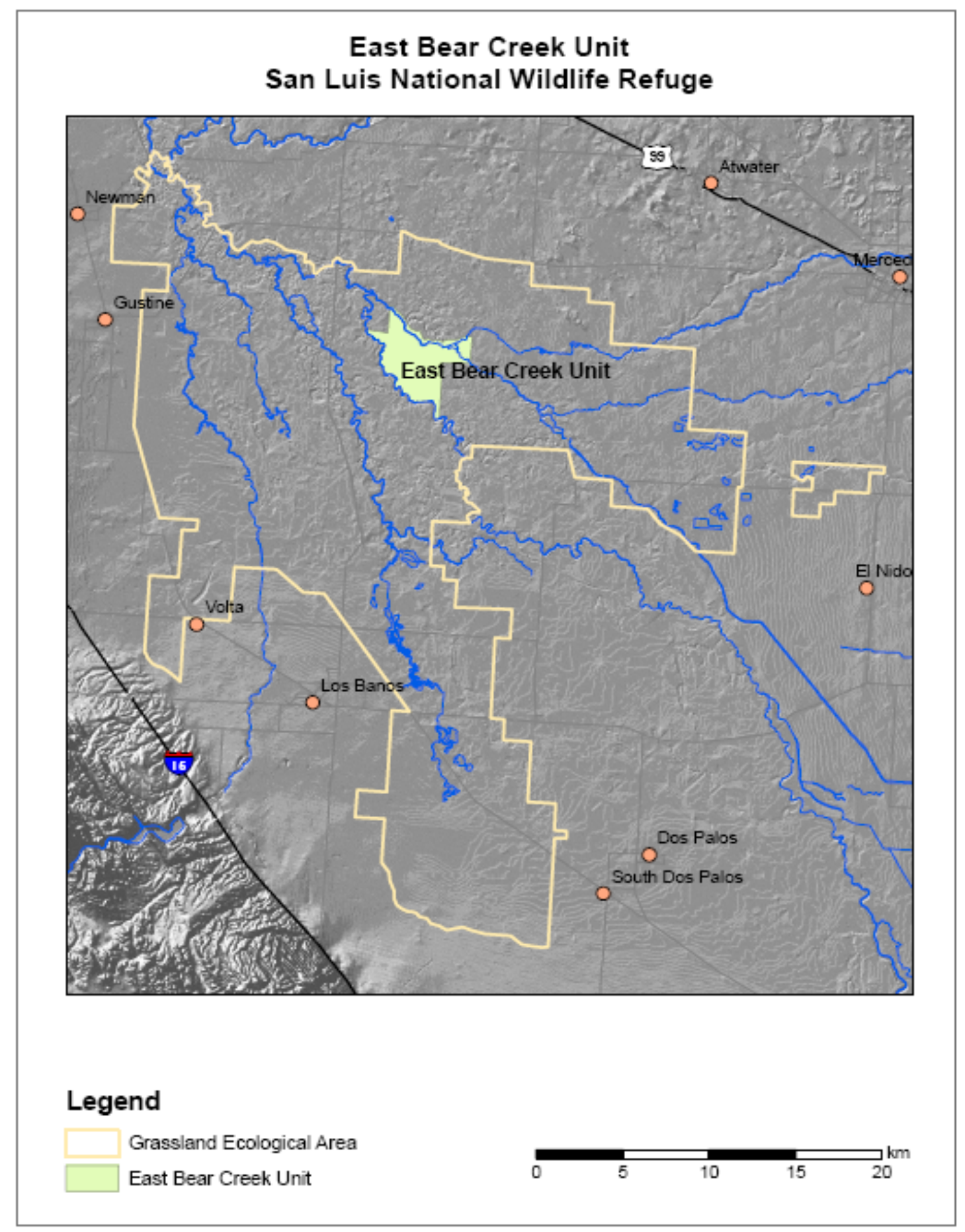

Figure 1. Location of East Bear Creek Unit within the San Luis National Wildlife Refuge Complex. 


\subsection{Regional geology}

The San Joaquin River Basin is a large structural trough filled with approximately 16,000 feet of eroded sediments from the granitic Sierra Nevada and the marine shales and siltstones of the Coast Range. These sediments derived from alluvial fans, rivers and shallow lakes that formed complex layered beds of various geologic materials that were later folded by landforming stresses in the earth's mantle. A generalized regional San Joaquin Valley cross-section is provided in Figure 2 (Bookman-Edmonston, 2003).

The preponderance of flow from east-side streams has given the San Joaquin Basin an asymmetric form with distances from the rim of the basin to the valley axis almost as wide on the east side compared to the west side. This produces steeper topographic gradients of between 20 and $40 \mathrm{ft}$ per mile on the west side compared to shallow gradients of 6 to $8 \mathrm{ft}$ per mile on the east-side (Mendenhall, 1908). Groundwater flow along the valley axis is slow, allowing time for capillarity and evaporation to concentrate salts in the shallow aquifer - especially in proximity to the valley trough.

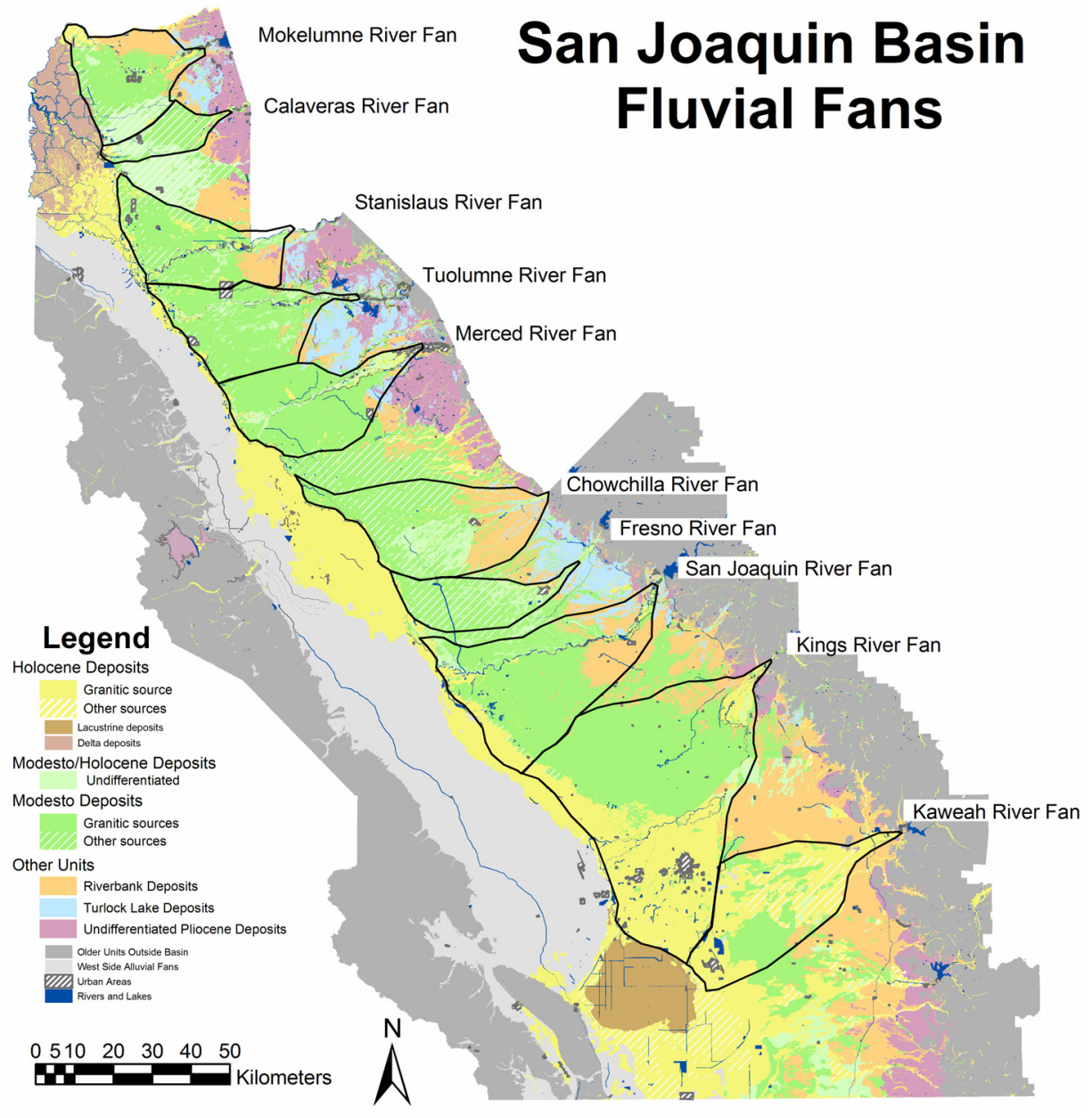

Figure 2. San Joaquin Basin Fluvial Fans. (Weissman G. et al. 2006. Presentation on : "Coarse-Grained Incised Valley Fill Deposits in the Tuolumne River Fluvial Fan: Implications for Artificial Recharge"). 
The chemical character of the groundwater aquifers are related to their geology. Valley alluvium, derived from Cretaceous and Tertiary Coast Range formations are rich in soluble gypsum, sulfates and carbonates which leach large quantities of salt as they deep percolate to the water table. Waters derived from the eastside Sierran granites and metamorphic rocks contain potassium, sodium and calcium mineral species but these are in the form of less soluble silicate minerals which dissolve less readily (Mendenhall, 1908). In the Valley trough the groundwater aquifers show characteristics of both east and west-side influences with interfingering layers of sands and silty-clays that correspond to the dominant erosional environment at the time of formation.

The upper 1,500 $\mathrm{ft}$ of sediments is comprised of both young and old alluvium, continental deposits and the Mehrten Formation (USGS, 1973). The Younger Alluvium consists of narrow bands of fine sand, sand and gravel with little or no hardpan and typically is found along river courses. This alluvial material ranges in thickness from $0-100$ feet (USGS, 1973). The Older Alluvium is the more pervasive exposed structural unit in the vicinity of the East Bear Creek Unit.. This structural unit comprises interbedded sand, silt, clay and gravel with some hardpan at shallower depths, and ranges in thickness from 400 to 700 $\mathrm{ft}$ below the land surface (Bookman-Edmonston, 2003). The bottom of the Older Alluvium is typically between $400 \mathrm{ft}$ and $600 \mathrm{ft}$ below sea level and is apparent in driller's logs as a transition from coarse grained to fine grained sediments (USGS, 1971, 1973).

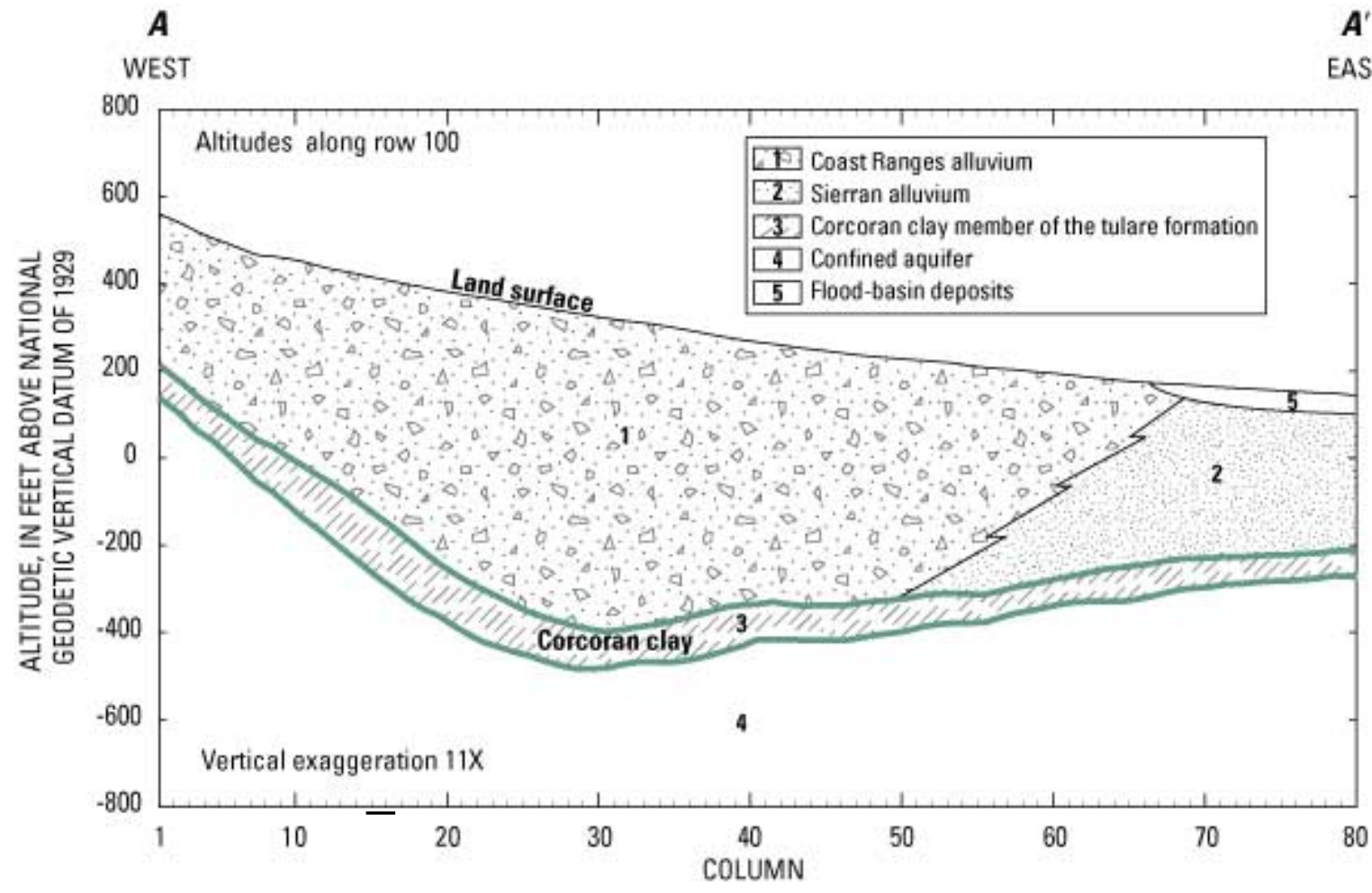

Note: 4 columns $=1$ mile

Figure 3. Generalized cross-section of the San Joaquin River Basin in proximity of the East Bear Creek Unit of the San Luis NWR Complex. (Brush et al., 2005)).

Embedded within the Older Alluvium are a number of continuous lacustrine deposits of gray and blue silts, silty clays and clays that display low permeability and act as impermeable barriers to vertical groundwater movement (Figure 3). The most significant of these deposits is the Corcoran "E" Clay which is regionally extensive in the Valley trough between Tracy and Kern County and which pinches out close to the alignment of Highway 99 in the eastern San Joaquin Valley, north of Chowchilla and in the vicinity 


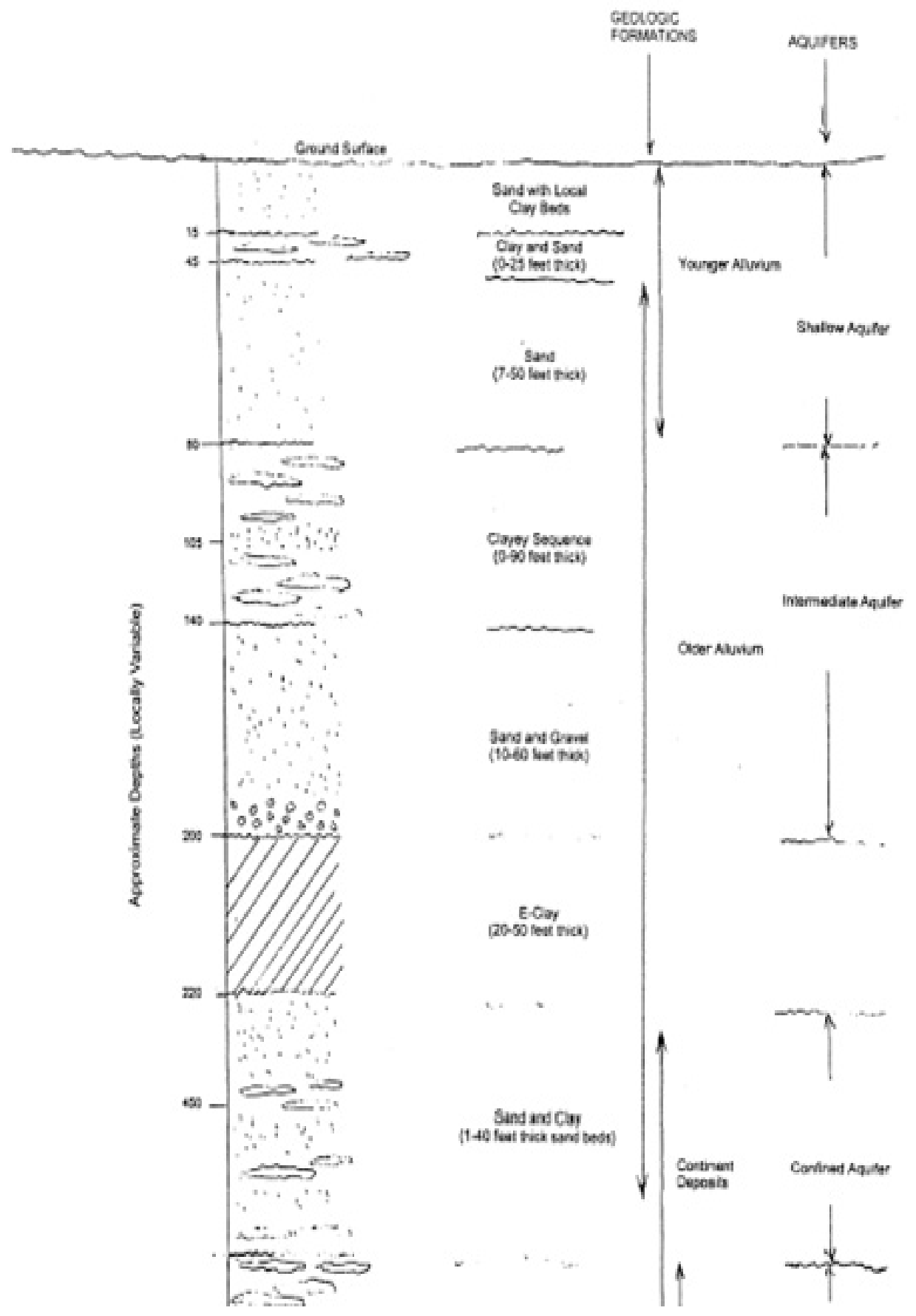

Figure 4. Generalized structural profile of sedimentary deposits and groundwater aquifers in the vicinity of East Bear Creek Unit in the San Luis NWR Complex. (Source : Bookman-Edmonston, 2003). 
of Highway I-5 in the western San Joaquin Valley. In western Merced County the Corcoran Clay extends to Merced and Atwater and hence underlies the extent of the East Bear Creek Unit. The Corcoran Clay is at its thickest in the Valley trough reaching thicknesses of 80-100 ft (Bookman-Edmonston, 2003). It is approximately $60 \mathrm{ft}$ thick in the vicinity of the East Bear Creek Unit.

The Continental Deposits are to be found beneath the Older Alluvium - the base of the Deposits extend to between $400 \mathrm{ft}$ and $800 \mathrm{ft}$ below sea level (Bookman-Edmonston, 2003). Water quality in the upper sections of the Continental Deposits is acceptable for many uses with an average electrical conductivity (EC) below 3,000 umhos/cm. The "base" of this fresh water - typically defined as the interface between water with an EC below $3000 \mathrm{uS} / \mathrm{cm}$ and poorer quality water - is not well defined and has been mapped by the USGS to be approximately $500 \mathrm{ft}$ below mean sea level. Beneath the Continental Deposits lies the Mehrten Formation which is comprised of deposits of sandstone, tuff, siltstone, breccia, claystone and conglomerate often referred to by local drillers and "black sand and gravel" (Bookman-Edmonston, 2003; USGS, 1973). Although the depth of this formation is generally unknown because no wells have been sunk this deep, largely on account of abundant shallow water resources, it is an important aquifer in both the Sacramento and San Joaquin Valleys and has permitted well production between 1,500 and 3,500 gpm (Bookman-Edmonston, 2003).

\subsection{Local hydrogeology}

The local geology dictates the nature of the local groundwater system and can be derived from well driller's reports, geophysical logs, consultant reports and agency hydrogeological studies in the vicinity of the East Bear Creek Unit. The distal end of the sedimentary deposits within and between major alluvial fans are characterized by having finer sediment texture and are often discharge zones where water originating from higher elevations on the east side of the San Joaquin Valley is forced under pressure upward through the near surface formations to discharge into sloughs and other surface drainages into the San Joaquin River.

Surface soils within the East Bear Creek Unit boundary are predominantly classified as Raynor clay, Temple loam, Merced clay loam, Fresno loam, Hilmar loamy sand (both well drained and poorly drained types), Kesterson sandy loam and Waukena loam soil associations. Soils investigated by Reclamation (Sherer, 2003) from drill holes SPT-OW/PW-02-1 through 3, SPT-OW-02-4 through 11, SPT-OW-02-11 through 15 and SPT-OW-02-25 through 26 suggested an area characterized by fine grained soils between 5 and 20 feet thick that overlie sands typical of those in the vicinity of the San Joaquin River (Figure 4, Figure 7). The fine grained deposits contain various combinations of fat and lean clays, sands and silts.

Figure 5 shows the local relief in the East Bear Creek Unit, which is flat between the levees to the north and west associated with Bear Creek and the San Joaquin River. In the north-eastern corner of the East Bear Creek Unit, Deep Slough bifurcates from East Bear Creek at the location of a small impoundment. The locations of the known groundwater wells are shown in Figure 4. Wells labeled EB-IW-01 and EBIW-02 are both inactive wells with intact well casing. Well EB-IW-03 is a non-functional well in poorer physical condition than the first two. Well EB-IW-04 has been destroyed and cannot be rehabilitated.

Figure 6 is a Landsat image that shows the moisture status of surface soils within the East Bear Creek Unit suggesting that the surface vegetation is more abundant and of higher moisture status in the northeastern sector of the Unit than in the remainder. This might be attributed to higher water tables in this sector or possibly the presence of a groundwater discharge area adjacent to the San Joaquin River levee. Discharge areas are associated with coarse textured soils (Figure 7), high near surface soil salinity and high concentrations of salt within the near-surface groundwater system. 


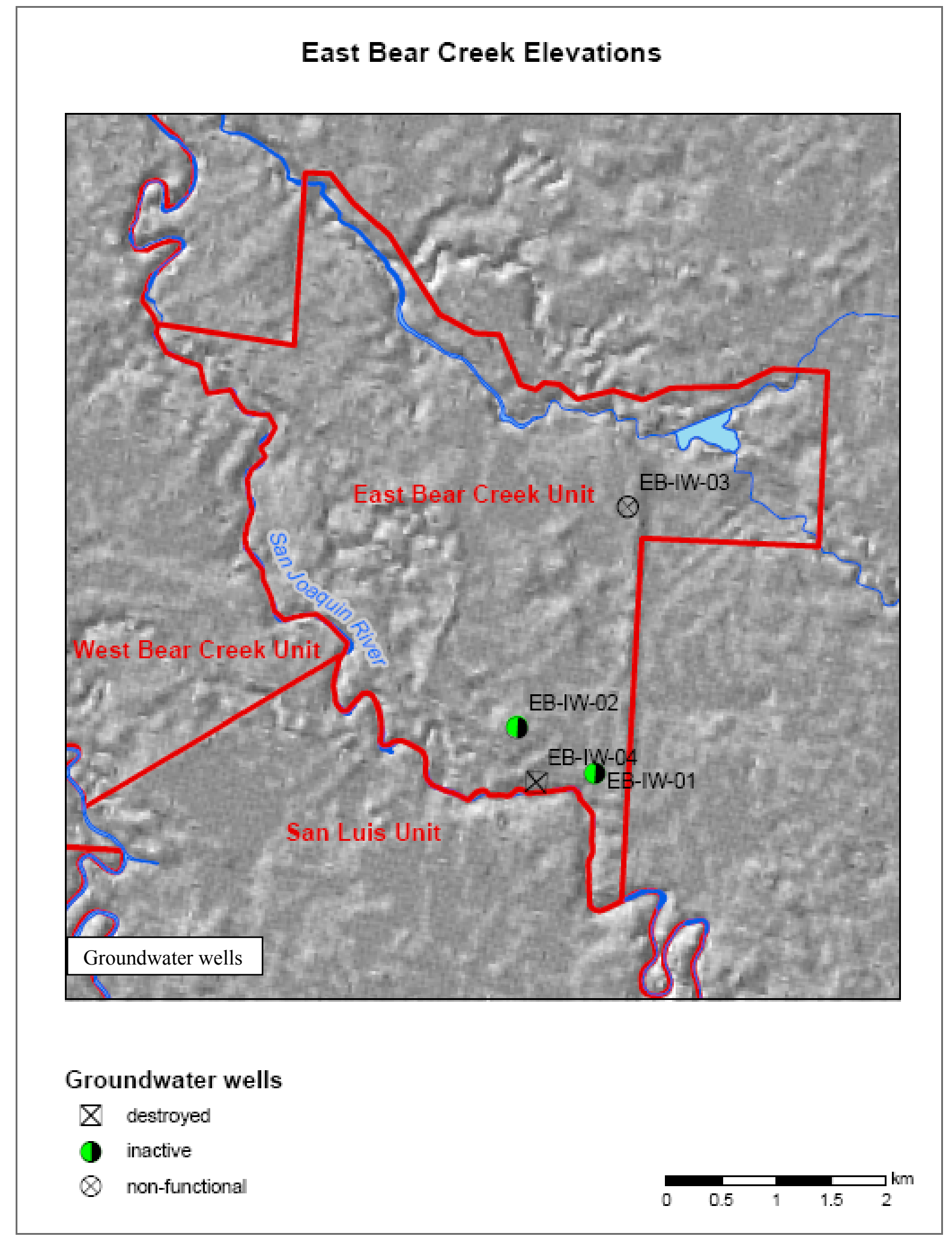

Figure 5. Surface relief on the East Bear Creek Unit within the San Luis NWR Complex showing the location of former production wells and their current status. 


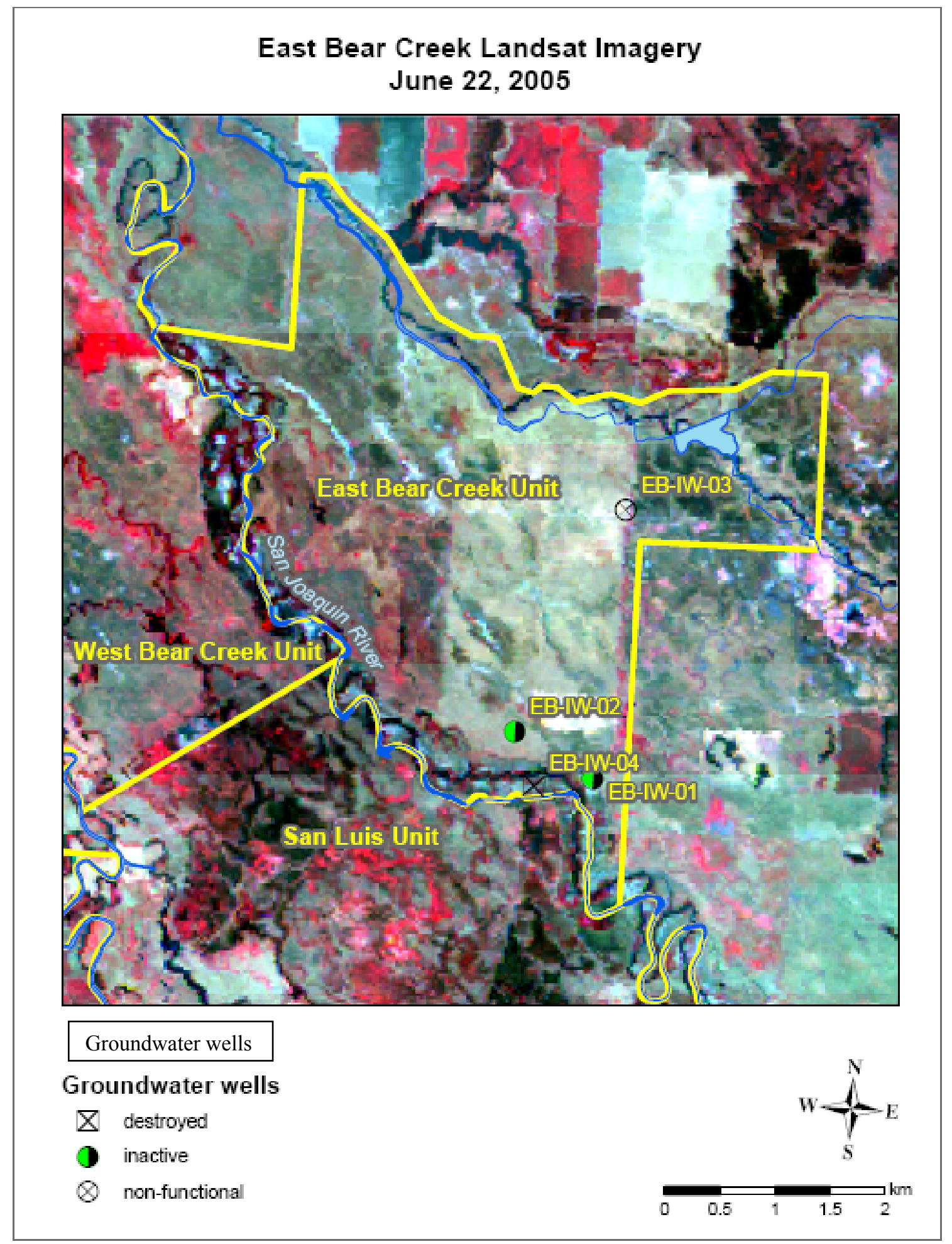

Figure 6. Satellite imagery of the East Bear Creek Unit within the San Luis NWR Complex showing the moisture status of soils and predominance of surface vegetation. Interpretation of the Landsat image suggests a higher moisture status in the north-east sector of the Unit closest to the San Joaquin River where water tables may be closer to the land surface. 


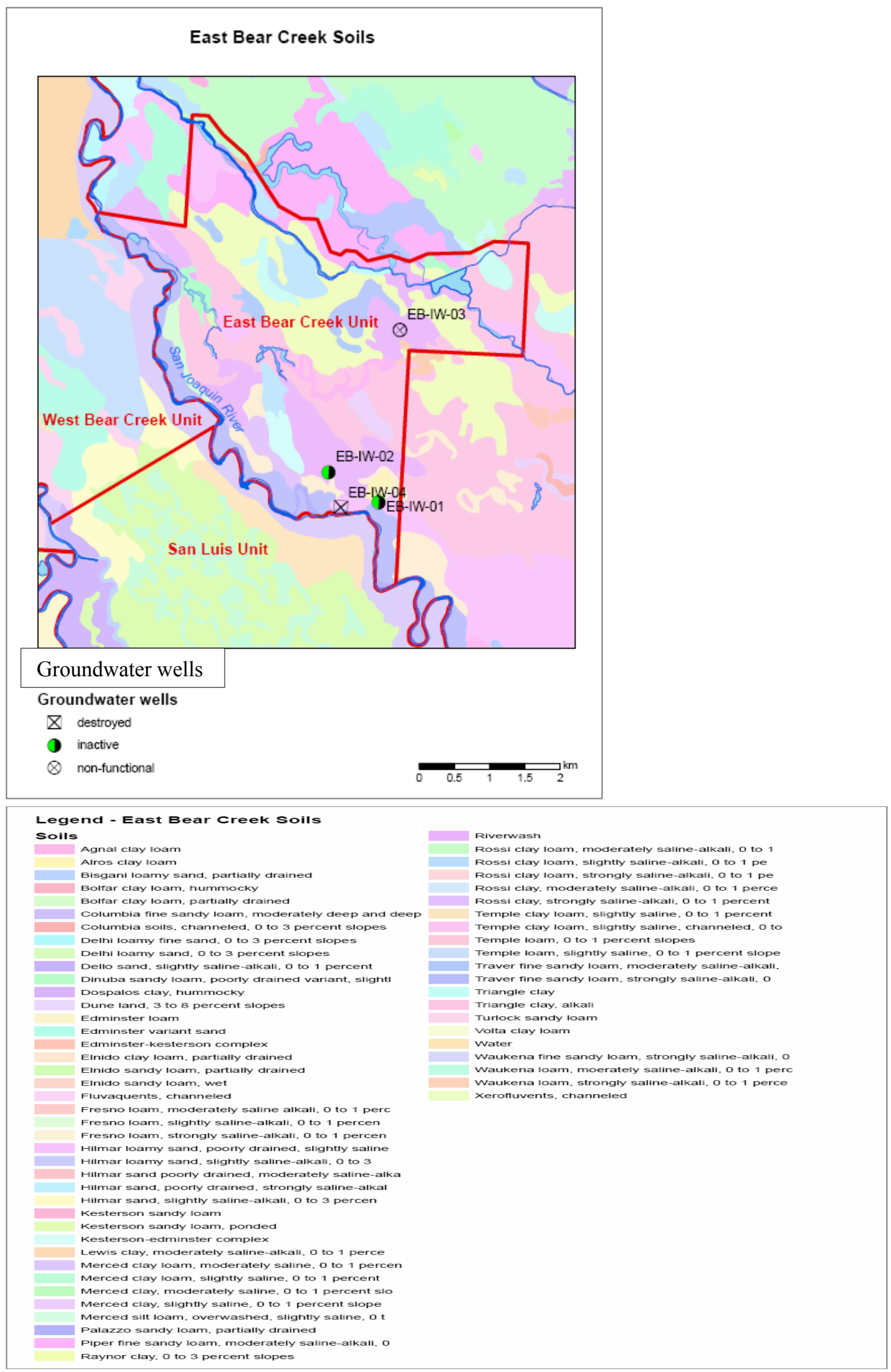

Figure 7. East Bear Creek Unit soil associations. 


\subsection{Cone penetrometer (CPT) logging}

Cone Penetrometer Logging (CPT) was conducted at the East Bear Creek Unit to develop a better understanding of the sedimentary geology of the semi-confined groundwater. During the CPT logging experiments, a conical-shaped probe instrumented with sensors was pushed into the ground up to depths of 120 feet. The cone penetrometer used at the East Bear Creek Unit contained sensors that continuously measured the friction sleeve, tip resistance, and electrical conductivity. A calibration curve was developed to convert bulk soil salinity measurements made with the CPT sensor to an equivalent soil solution salinity. Both Myron Inc. and YSI Inc. soil salinity sensors were used to develop this calibration curve. During the experiments it was noted that saturation occurred in the CPT electrode at bulk salinity concentrations above $600 \mathrm{mS} / \mathrm{m}$ - above this threshold the relationship between bulk salinity and EC became highly non-linear. Since the groundwater underlying much of the managed wetland area in the San Joaquin Valley has an EC below $9000 \mathrm{uS} / \mathrm{cm}$ - the non-linear portion of the calibration curve was eliminated and a best fit least squares calibration curve fitted (Figure 8).

The best-fit equation was shown to be :

$\mathrm{EC}(\mathrm{uS} / \mathrm{cm})=13.567 *$ bulk salinity $(\mathrm{mS} / \mathrm{m})$

This equation has a regression coefficient of $0.9983(\mathrm{mg} / \mathrm{l})$

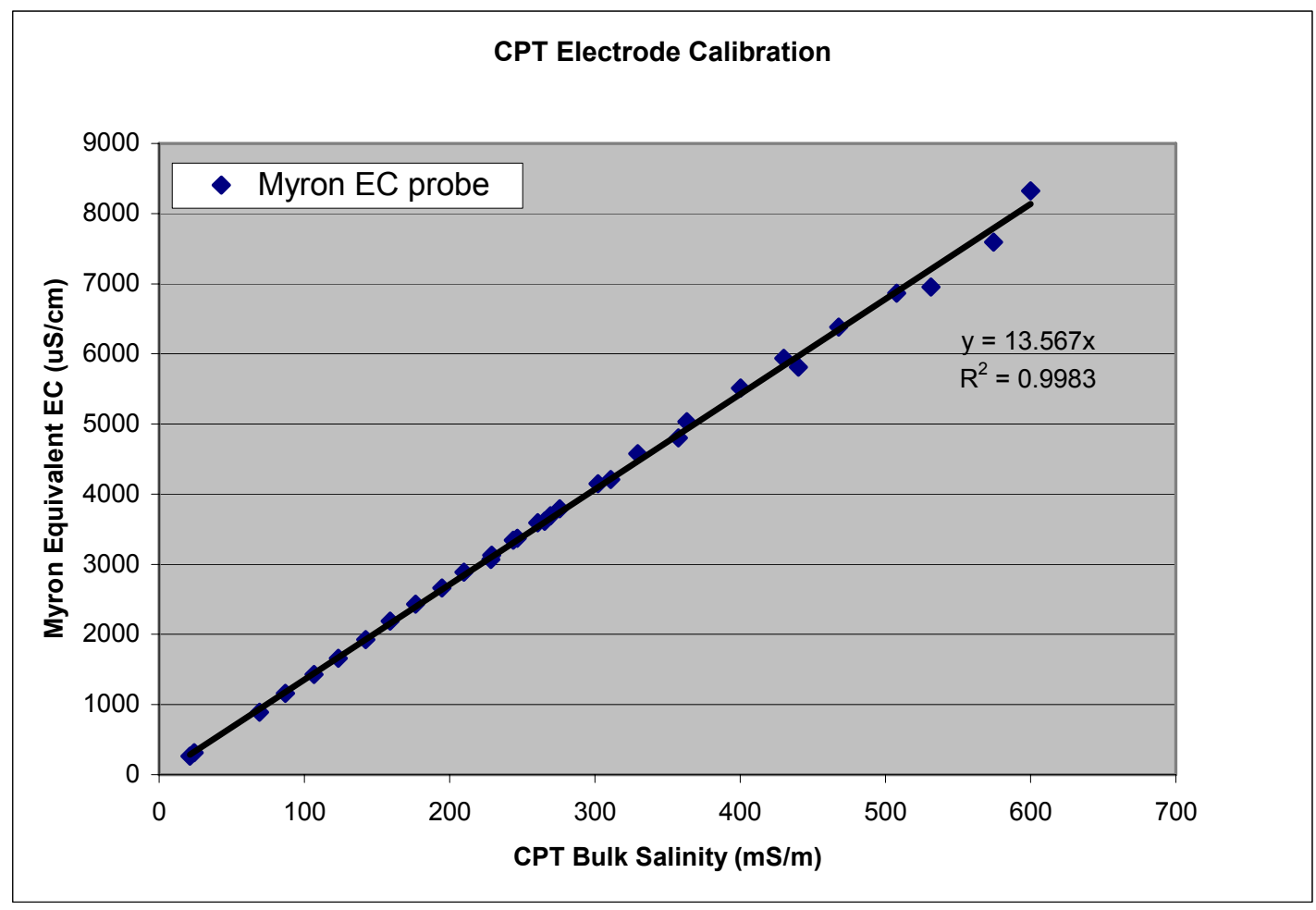

Figure 8. Calibration curve for converting CPT bulk salinity measurements $(\mathrm{mS} / \mathrm{m})$ to an equivalent groundwater EC (uS/cm).

Plots of the CPT sensor data with depth are shown in Figures 9 and 10 for two locations at the East Bear Creek Unit. The maximum depths of the CPT logs ranged from $110 \mathrm{ft}$ to $120 \mathrm{ft}$ in the two locations. 


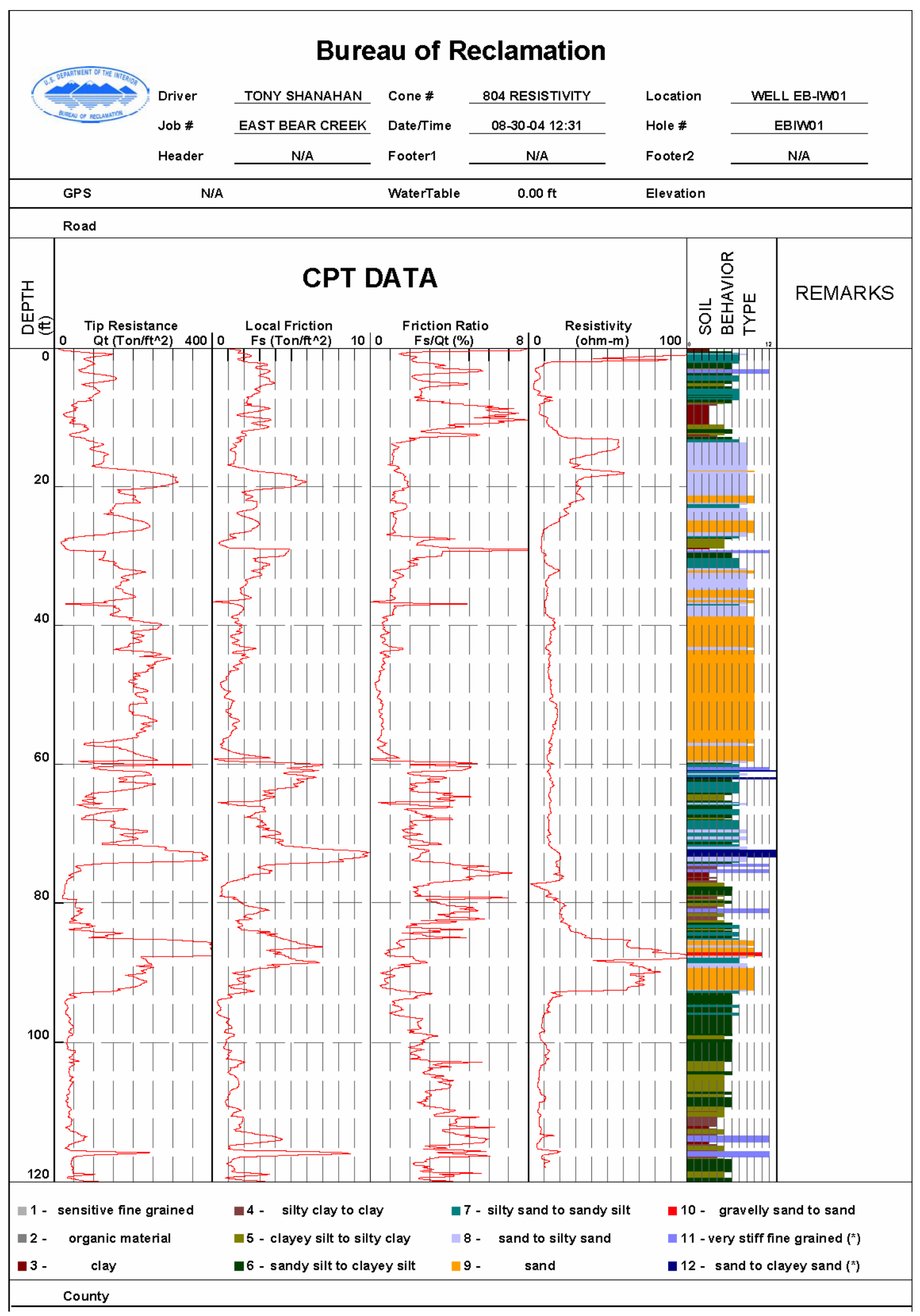

Figure 9. CPT log for well EB-01 in the East Bear Creek Unit of the San Luis NWR Complex. 


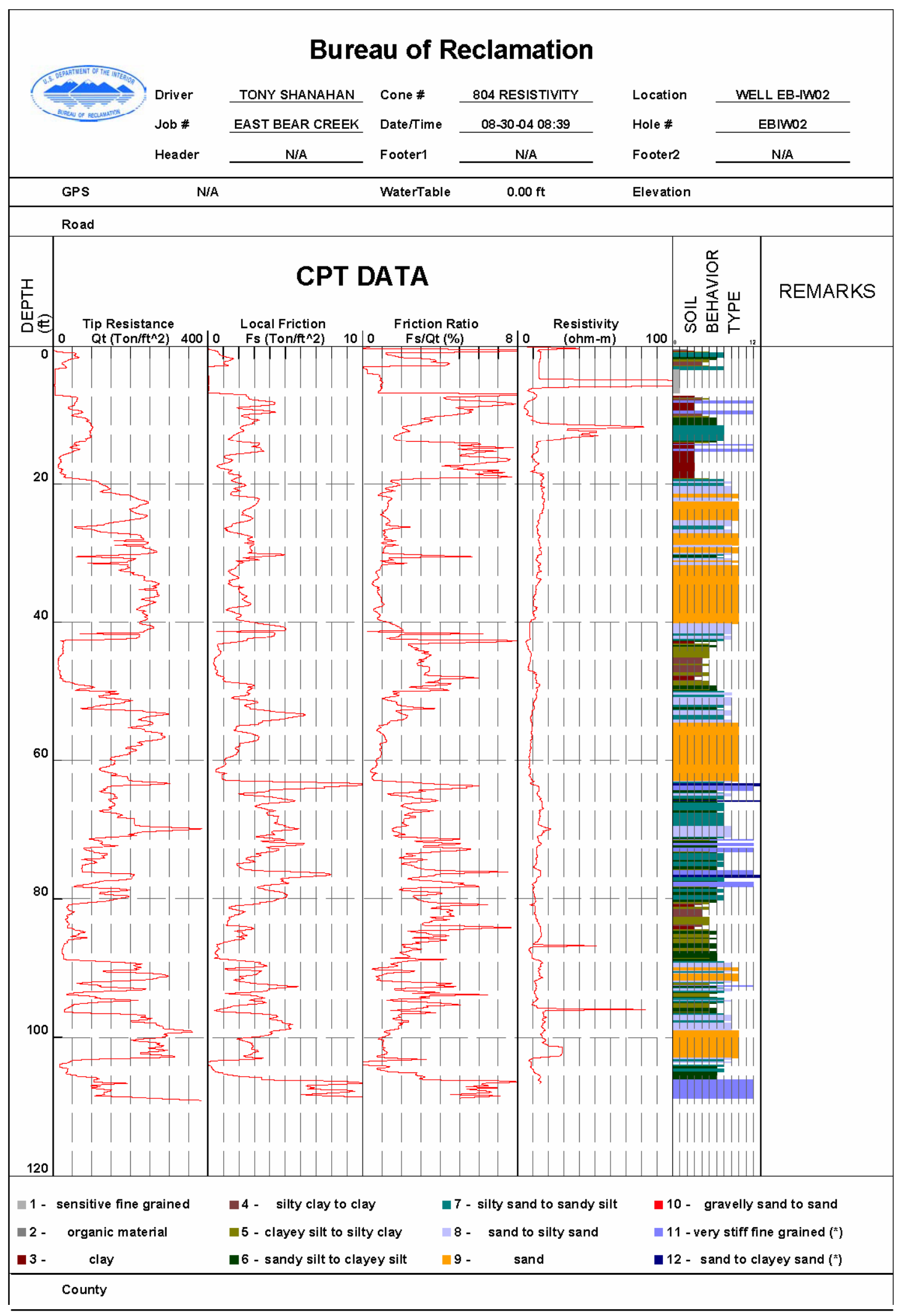

Figure 10. CPT log for well EB-02 in the East Bear Creek Unit of the San Luis NWR Complex 


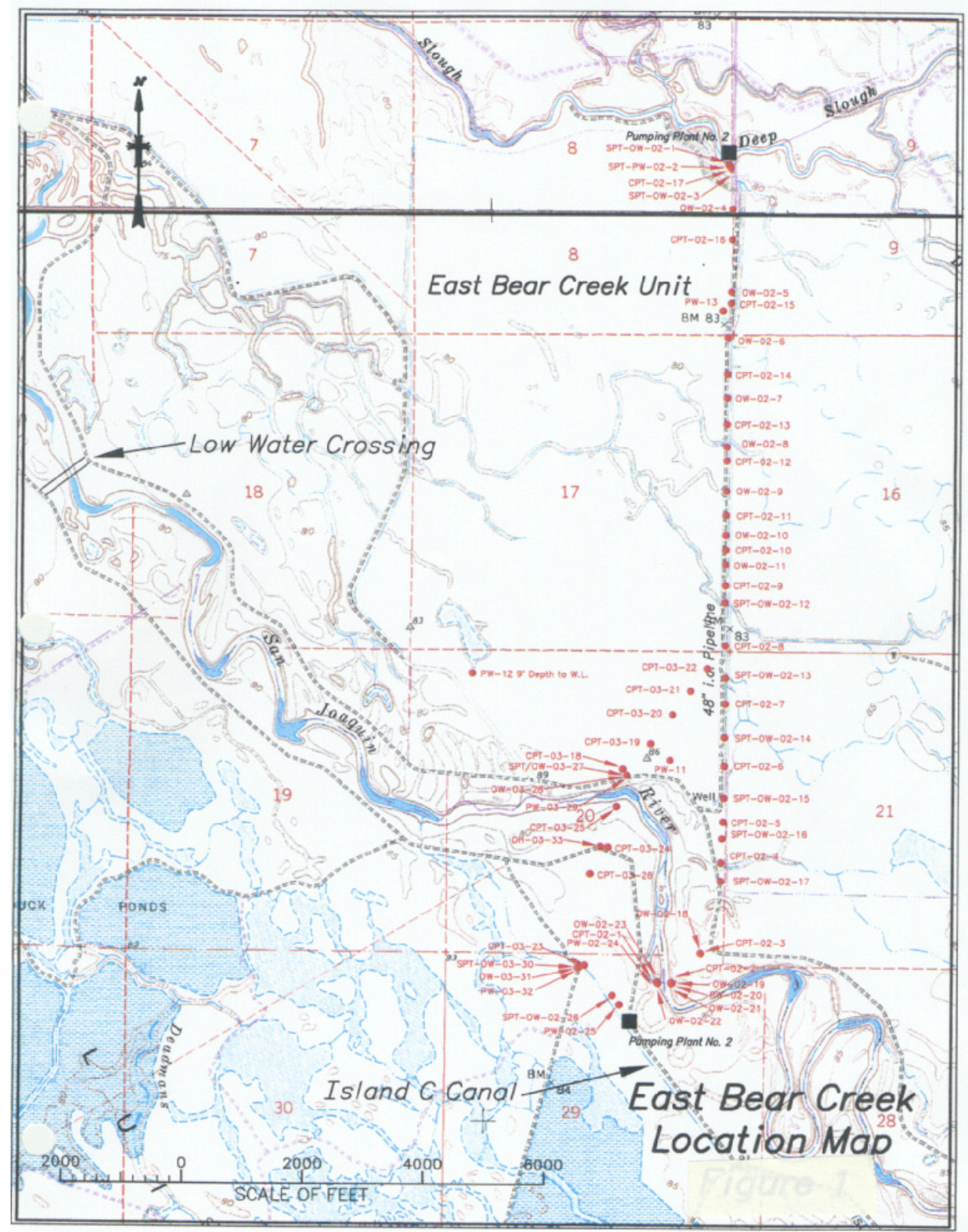

Figure 11. Location of CPT logs taken within the East Bear Creek and West Bear Creek Units for analysis of water supply conveyance options (Sherer, 2003).

In Figure 9, sand layers are found at about $20 \mathrm{ft}$ below the surface and extend down to about $92 \mathrm{ft}$ in this deep abandoned well (EB-01/EB-IB-01). The highest permeability continuous sand layer occurs in a depth interval of $40 \mathrm{ft}$ to $60 \mathrm{ft}$ below the surface. A second smaller sand layer appears between $86 \mathrm{ft}$ and $92 \mathrm{ft}$ below the surface. Provided these sand layers are laterally continuous they may provide a sufficiently extensive shallow aquifer for exploitation. Bulk pore water salinity derived from the resistivity cone data is elevated at the near surface (vadose zone) with readings in excess of 1,000 $\mathrm{ms} / \mathrm{cm}$ (out of range but likely in excess of $10,000 \mathrm{uS} / \mathrm{cm}$ ) diminishing to a concentration of about $100-$ $200 \mathrm{mS} / \mathrm{m}(1300-2600 \mathrm{uS} / \mathrm{cm})$ below a depth of about $17 \mathrm{ft}$. Groundwater quality is mostly in this range except for two depth intervals; between $17 \mathrm{ft}$ and $25 \mathrm{ft}$ where the EC equivalent rises to 600 
$\mathrm{mS} / \mathrm{cm}$ - about 8,000 uS/cm; and between $85 \mathrm{ft}$ and $94 \mathrm{ft}$ where the EC climbs as high as 1,000 mS/cm - again out of the instrument range, but likely in excess of $10,000 \mathrm{uS} / \mathrm{cm}$. This high concentration occurs adjacent to the lower sand layer - suggesting that water may be migrating in to this area.

In Figure 10 the aquifer stratigraphy observed at the abandoned well (EB-02/EB-IW-02) is similar to the stratigraphy at well EB1 although the test wells were more than 1 mile apart. The CPT log shows a larger fraction of finer grade material. Silty sands and intermediate sand-silty sands predominate over an aquifer that lies between $22 \mathrm{ft}$ and $63 \mathrm{ft}$ below the surface. The porosity and the specific yield of these aquifer materials are lower than that of sand. A clay aquitard, probably the "C" Clay, that is approximately $15 \mathrm{ft}$ thick, lies immediately below the sand-silty sand aquifer. The water quality profile near production well 7 is similar to that at the abandoned well. Bulk salinity concentrations are high in the vadose zone but diminishes to under $50 \mathrm{mS} / \mathrm{m}(680 \mathrm{uS} / \mathrm{cm}$ equivalent groundwater EC) until a depth of $62 \mathrm{ft}$ below where the concentration increases to $150 \mathrm{mS} / \mathrm{m}(2,035 \mathrm{uS} / \mathrm{cm}$ equivalent groundwater $\mathrm{EC})$.

During 2003 Reclamation completed a series of groundwater studies related to the alignment of a water supply pipeline for two pumping plants designed to convey Level 4 water to the East Bear Creek Unit. CPT logs and a series of aquifer tests were conducted at test sites within both East and West Bear Creek Units. Figure 11 shows the locations of the CPT tests as well as the pumped wells and observation wells that were used in the aquifer tests. Figures 12 - 16 show the aquifer stratigraphy that was derived from the CPT logs that were conducted during these investigations. The CPT logs CPT-03-18 through CPT03-03-22 were made within the south-west sector of the refuge whereas logs CPT-03-23 and CPT-0303-26 were made within the west Bear Creek Unit west of the San Joaquin River. Unlike the previous logs in Figures 9 and 10 these CPT logs only reported on the top $35-50 \mathrm{ft}$ of the groundwater aquifer. Bulk salinity was not logged during these tests.

Analysis of the plots shows a consistent lens of porous sands and silty sands beginning between $6 \mathrm{ft}$ and $15 \mathrm{ft}$ below ground surface and of thickness between 20 and $40 \mathrm{ft}$. In most instances the depth of sand exceeds the depth of silty sand - both aquifer materials are capable of high vertical and horizontal transmissivities. Wells located in this porous strata, if hydraulically connected to streams such as Bear Creek or unlined conveyance structures, can show good water quality.

\subsection{Groundwater quality logging}

A significant obstacle to assessment of conjunctive use of water is inadequate data on the depth distribution of groundwater quality in the regional aquifer. In regions where the salinity of the groundwater varies considerably with depth, such as the Central Valley of California, an understanding of both the hydraulic properties of the aquifer and the depth distribution of salts is critical for evaluating the potential of aquifers for conjunctive water use. The electrical conductivity profiles recorded in a well using the flowing fluid electric conductivity logging (FEC logging) method can be analyzed to estimate interval specific hydraulic conductivity and estimates of the salinity concentration with depth (Su et al., 2006).

As described by Tsang and Doughty (2003), the flowing FEC logging method involves first replacing the well bore water by de-ionized water or water of a constant salinity distinctly different from that of the formation water. This is done by injecting de-ionized water down a tube to the bottom of the well, while simultaneously pumping from the top of the well, until the EC of the water pumped out of the well stabilizes at a low value. Next, the pumps are turned off and the well is pumped only from the top at a constant low flow rate, while an electrical conductivity probe is lowered into the borehole to record the $\mathrm{EC}$ as a function of depth and time. 


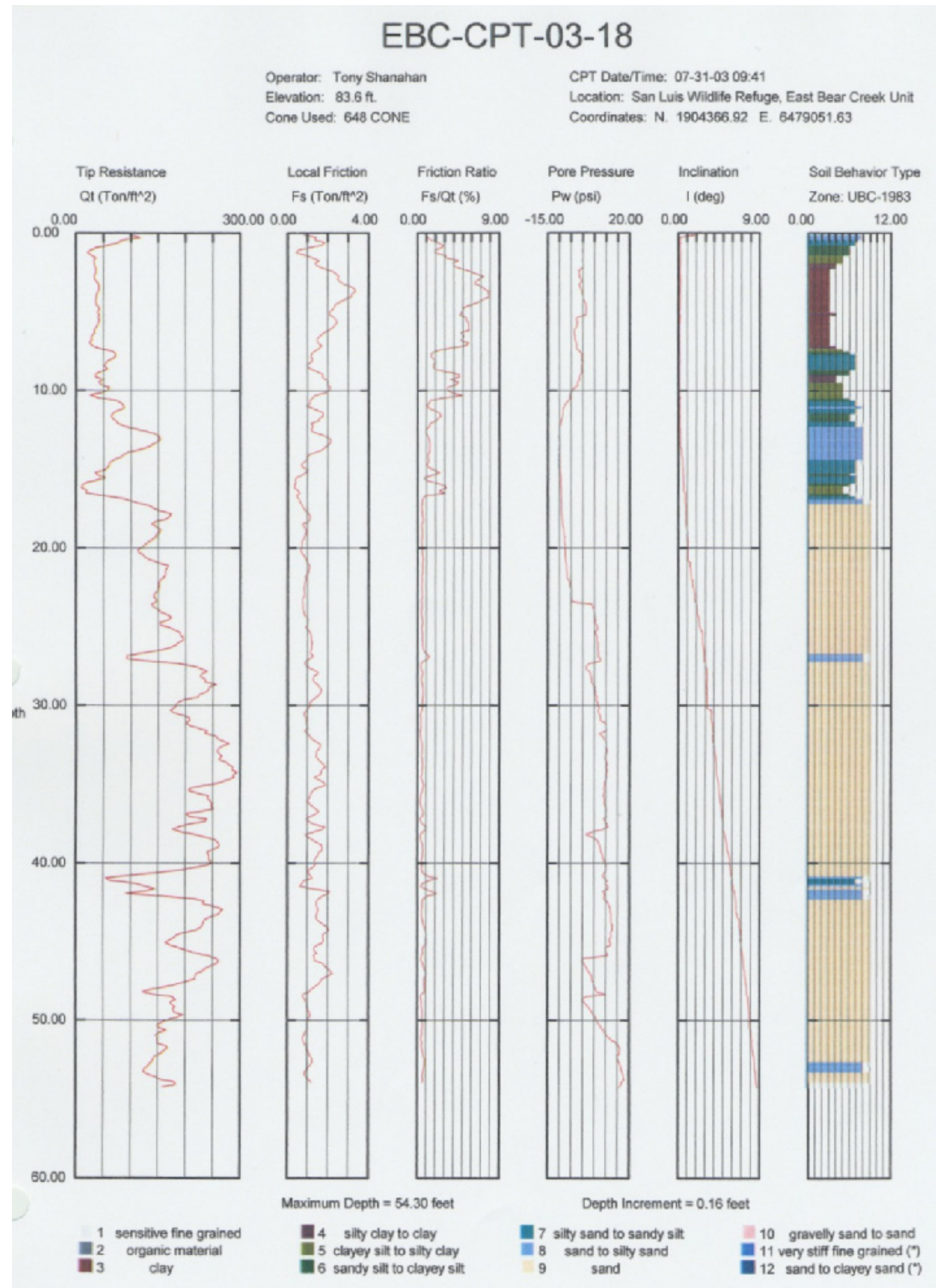

Figure 12. CPT Log CPT-03-18 in the East Bear Creek Unit of the San Luis NWR Complex 


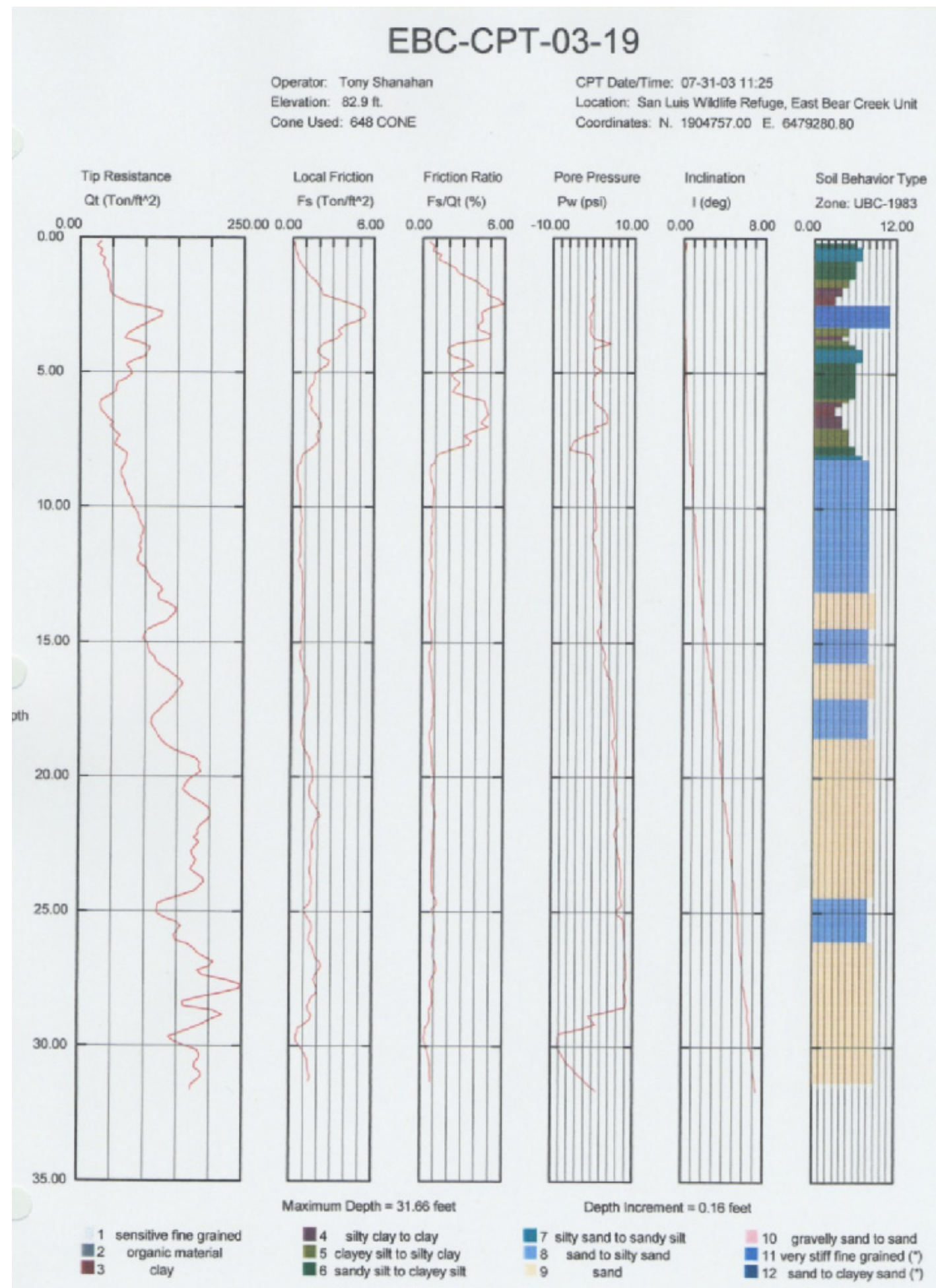

Figure 13. CPT Log CPT-03-19 in the East Bear Creek Unit of the San Luis NWR Complex 


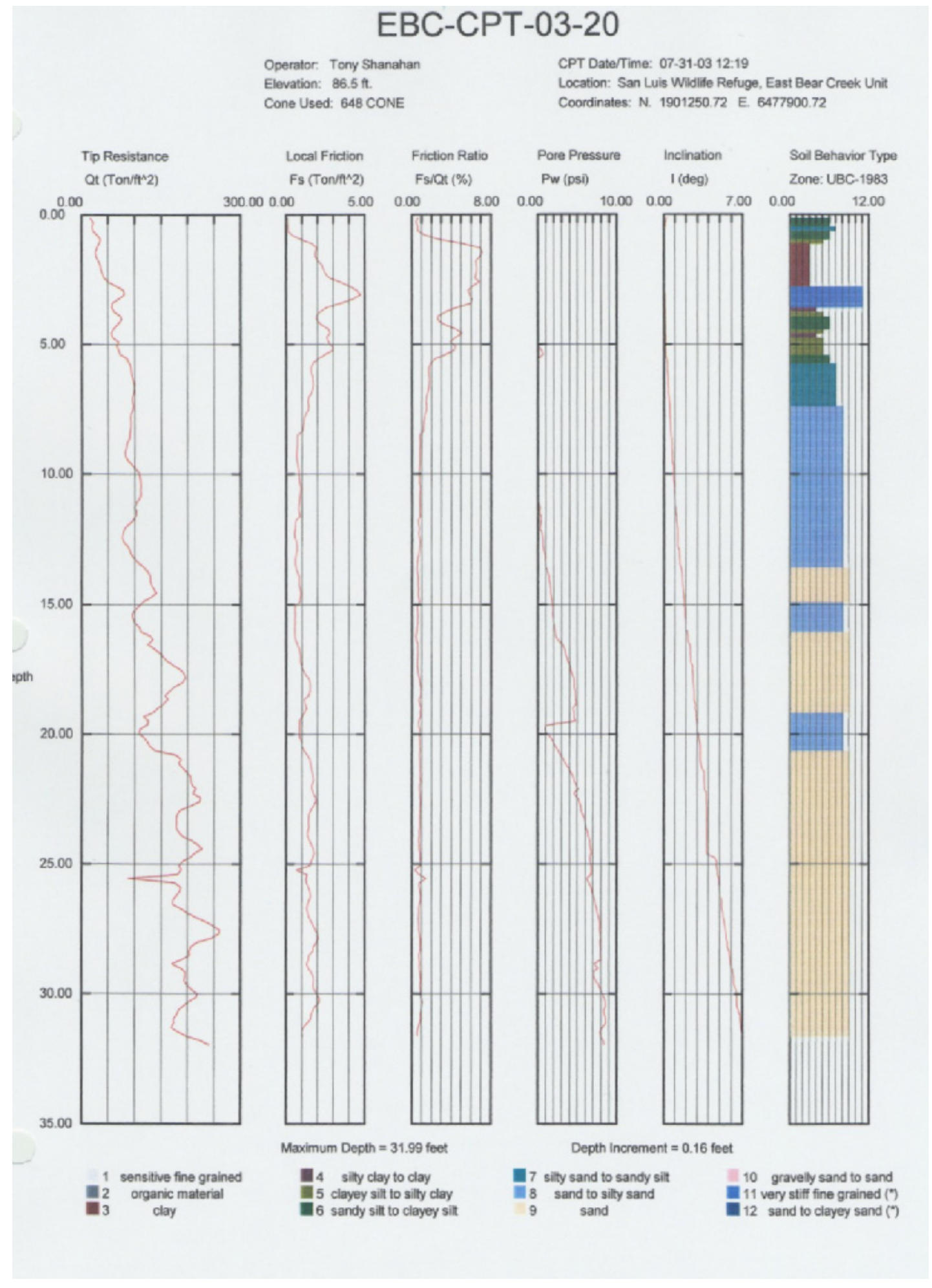

Figure 14. CPT Log CPT-03-20 in the East Bear Creek Unit of the San Luis NWR Complex. 


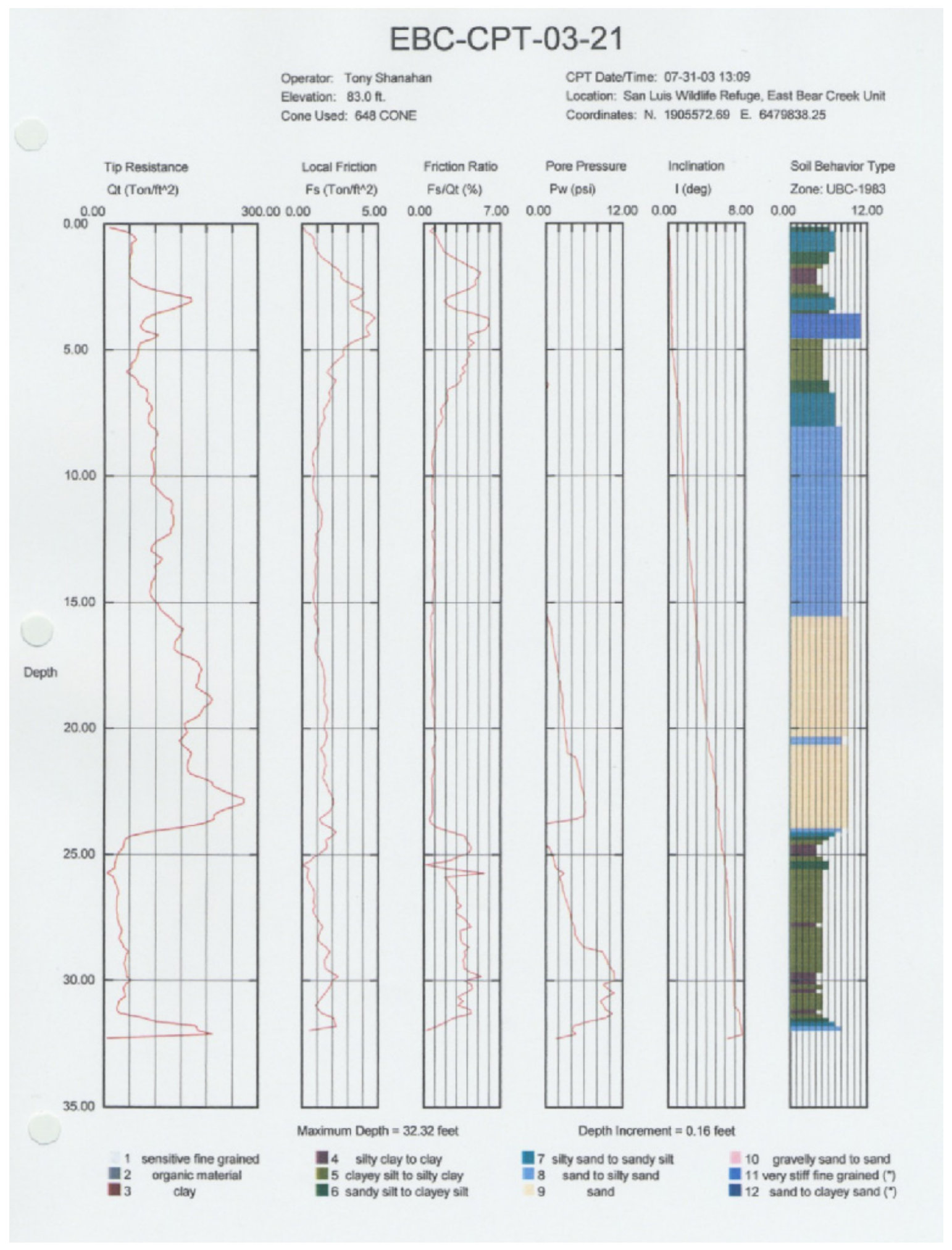

Figure 15. CPT Log CPT-03-21 in the East Bear Creek Unit of the San Luis NWR Complex 


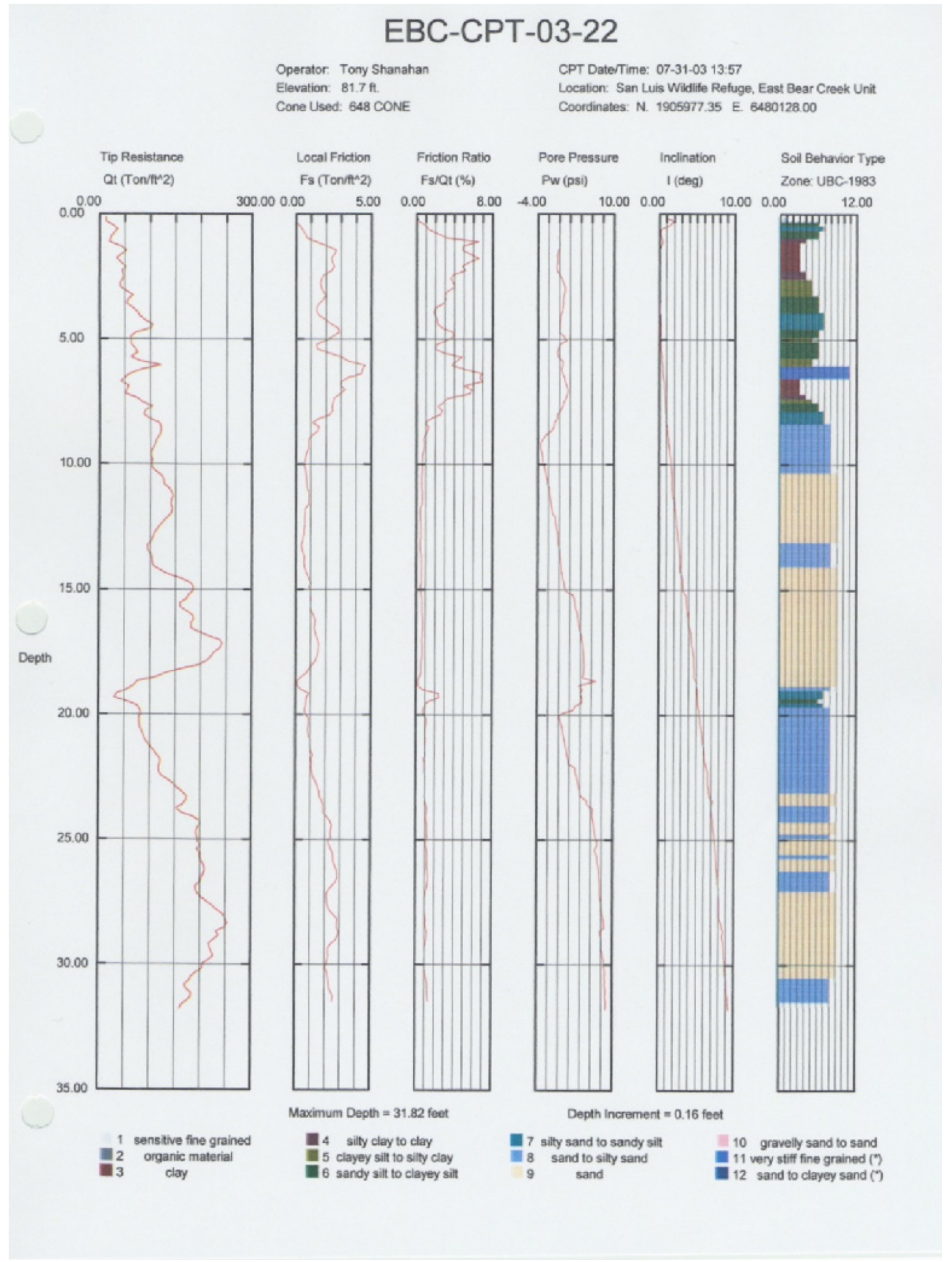

Figure 16. CPT Log CPT-03-22 in the East Bear Creek Unit of the San Luis NWR Complex. 


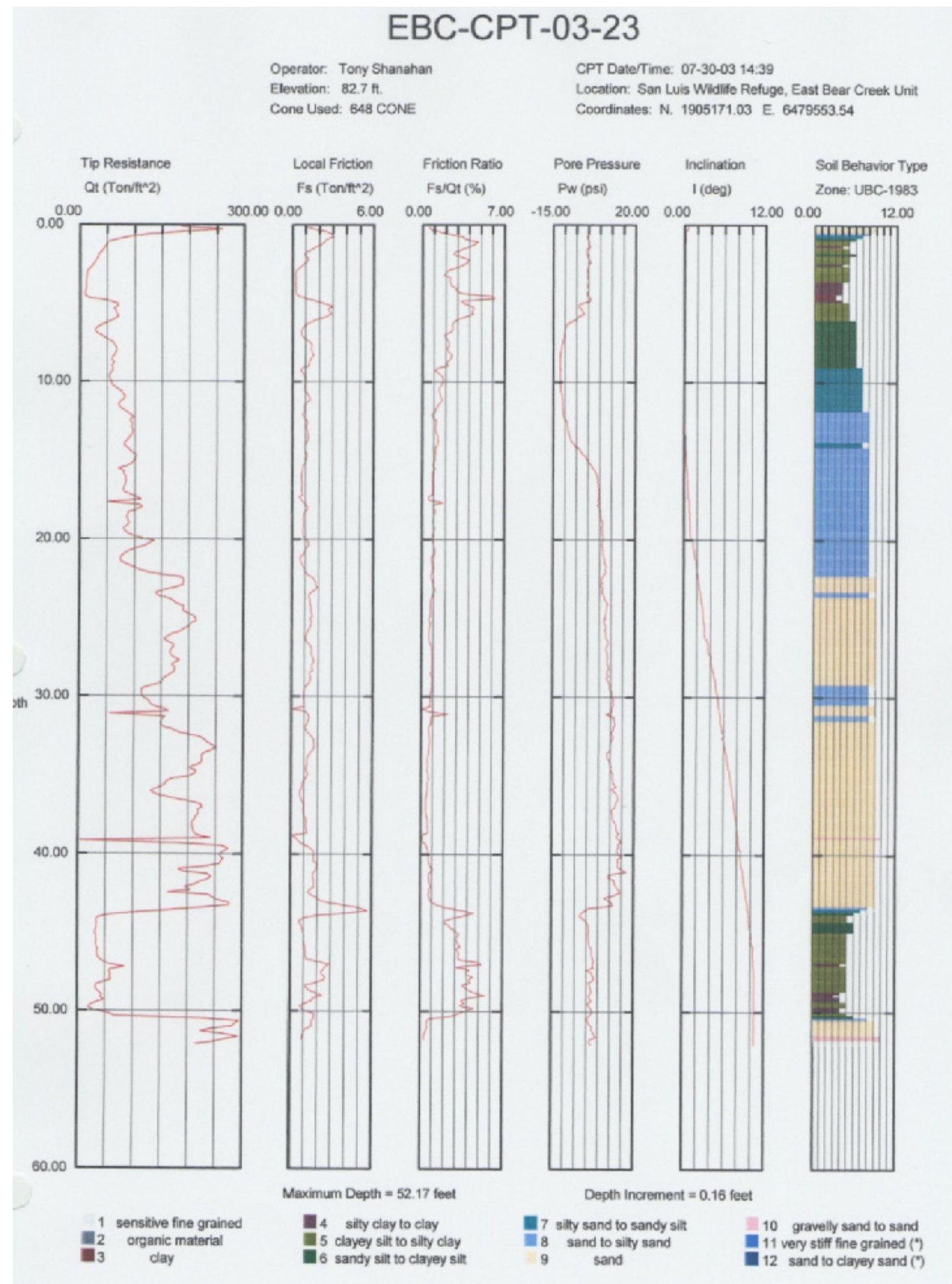

Figure 17. CPT Log CPT-03-23 in the East Bear Creek Unit of the San Luis NWR Complex. 


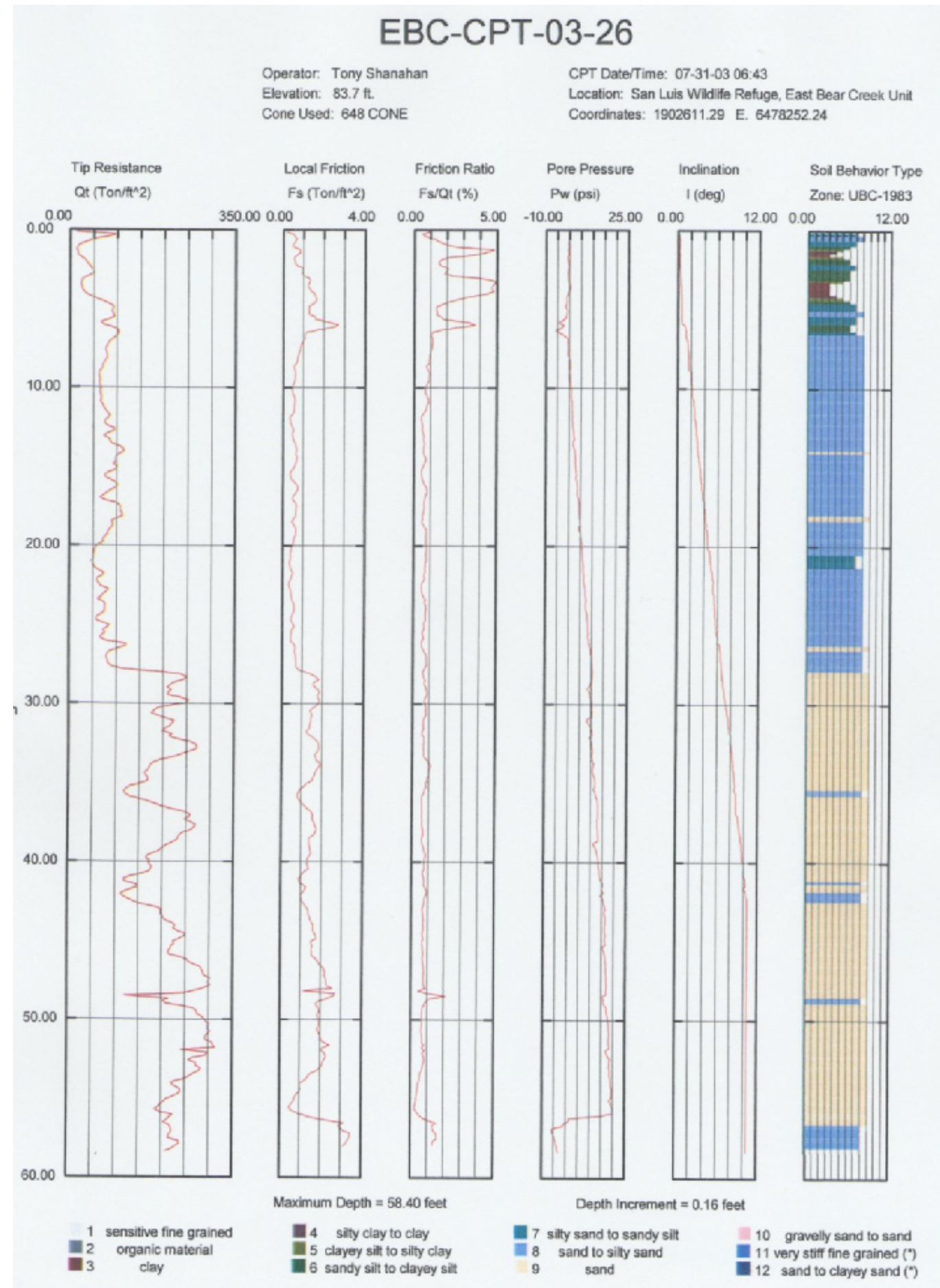

Figure 18. CPT Log CPT-03-26 in the East Bear Creek Unit of the San Luis NWR Complex. 


\subsubsection{Fluid Electrical Conductivity Logging in Limited Access Wells}

During traditional FEC logging, constant salinity water with salinity lower than the existing well bore water is injected at the bottom of the well screen simultaneously as the well bore water is extracted from the top of the well bore (Figure 19). The less dense, lower salinity water should theoretically move up the well bore as it displaces the existing water. In an unconsolidated formation, some of the injected water is likely to enter the formation over time, with more water entering the bottom of the formation where the water is injected. Injection of water into the irrigation wells with limited access is a challenge since the small diameter access pipe (11/2 in) limits the diameter of tubing that can be used in the well. In addition, both the injection and extraction hose must simultaneously fit through the pipe opening. FEC logging is typically performed in wells with diameters in range from $2-6$ ins. The diameter of the irrigation well casing used in this study is nearly 18 ins, so it would take a long time to replace the borehole water using tubing with a small diameter and a single injection point.

Because replacing the existing well water using a small diameter tube is difficult in these large diameter wells with limited access, we developed a new technique of injecting water using tubing with emitters to provide nearly uniform injection over the length of the well screen. Emitters were originally developed for drip irrigation in agricultural fields, but they have not been used to inject water into wells. Because of the pressure drop along the length of the tubing, pressure-compensating emitters were used to provide a uniform injection rate. The emitters were inserted into $3 / 4$ in diameter reinforced PVC tubing every foot $\mathrm{m}$ over a length of $75 \mathrm{ft}$ beginning at the bottom of the hose. Above the $75 \mathrm{ft}$ interval, the emitters were spaced at $2 \mathrm{ft}$ intervals for a total of nearly $125 \mathrm{ft} \mathrm{m}$ of hose with emitters. The total length of the hose was around $300 \mathrm{ft}$. The emitters are rated at $3.2 \mathrm{gals} / \mathrm{hr}$ for pressures between $10-50 \mathrm{psi}$, and we verified that the flow rate remained nearly constant as the pressure changed. The emitters maintain a constant flow rate with a flexible membrane that becomes compressed as the pressure increases. A constant flow rate is maintained because the permeability of the membrane decreases with increasing pressure. Our new injection method reduces the time of well water replacement compared to the traditional, single point injection method since the injection occurs over the screened interval and mixes with the existing water over that interval. The existing well water does not have to be entirely replaced as with the single point injection method because FEC logging still works as long as the low salinity water becomes wellmixed with the existing well water and the resulting water salinity has enough contrast with the formation EC (Su et al., 2006).

During the water-replacement part of our well logging tests, constant salinity water with an electrical conductivity between $0-500 \mathrm{mS} / \mathrm{cm}$ was injected into the well bore via emitters while the well bore water was simultaneously extracted from the top. Centrifugal pumps were used to inject and extract water, and the extraction and injection hose had a $3 / 4$ in diameter. A schematic of the experimental set-up is shown in Figure 12.

The electrical conductivity probes typically used to perform FEC logging have a 11/2 in diameter and have an inflexible $3 \mathrm{ft}-6 \mathrm{ft}$ long section. A probe of this size would not fit into most well access pipes and could not bend around the lip where the well casing and access pipe intersect. A small electrical conductivity probe manufactured by Campbell Scientific (Logan, UT) was used that had a crosssectional area of 1 in $x 3 / 4$ in and was 3.6 in long. The probe was made heavier using five stainless steel weights that had a 1 in diameter and were 2 in long to reduce the buoyancy of the probe. The probe depth was measured using a depth encoder, which is a device that detects depth measurements and converts them to electrical signals for input into data acquisition systems.

\subsubsection{Open, Abandoned Well EB-01}

The FEC logging conducted in the open, abandoned irrigation well in the East Bear Creek Unit was perforated from a depth of $170 \mathrm{ft}$ below ground surface to the bottom of the well. The well depth was estimated to be approximately $265 \mathrm{ft}$ (Figure 20). The water in this well was around $18 \mathrm{ft}$ below ground 
surface. Deionizing filters were used to reduce the salinity of the well water that was extracted. The extracted water was run through the filters and then the de-ionized water was injected into the well. The water was extracted/injected at a rate of $3.6 \mathrm{gal} / \mathrm{min}$ over a period of 5 hours.

After the 5 hour period of replacing the well bore water, the injection pump was shut off and only the extraction pump was maintained at a rate of $5 \mathrm{gal} / \mathrm{min}$, and the EC profile in the well was logged for the next 3 hours. The initial EC profile in the well before water was extracted/injected and the subsequent hourly EC profiles after the water replacement had ceased and water was only extracted are presented in Figure 20.

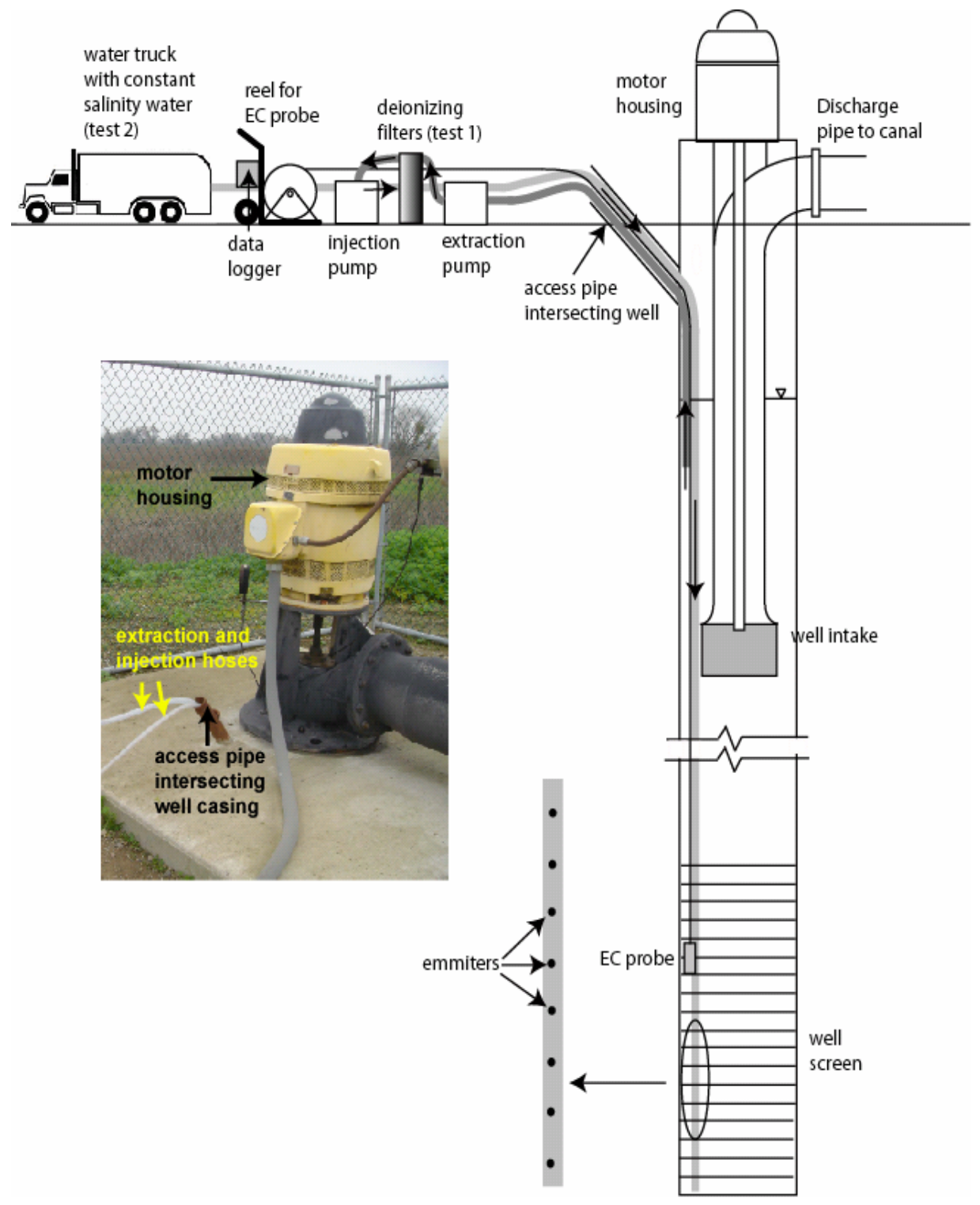

Figure 19. Schematic and photograph of a limited-access well that FEC logging was conducted in using our modified technique. 
The shallow aquifer from the water table down to $150 \mathrm{ft}$ shows an initial EC profile of approximately $1,000 \mathrm{uS} / \mathrm{cm}$ with a spike in concentration at about $75 \mathrm{ft}$ where the EC reaches $1,400 \mathrm{uS} / \mathrm{cm}$. Continued pumping of the well caused the EC in the top $150 \mathrm{ft}$ of the well to improve over time as some of the deionized water moves upward from the screened interval of the well where deionized water was injected. Over the screened interval, the initial EC profile is nearly uniform at $2650 \mathrm{uS} / \mathrm{cm}$. Continued pumping of the formation causes the EC to increase over time as formation water displaces the lower concentration water in the well bore. The EC stablilizes at about $2900 \mathrm{uS} / \mathrm{cm}$.

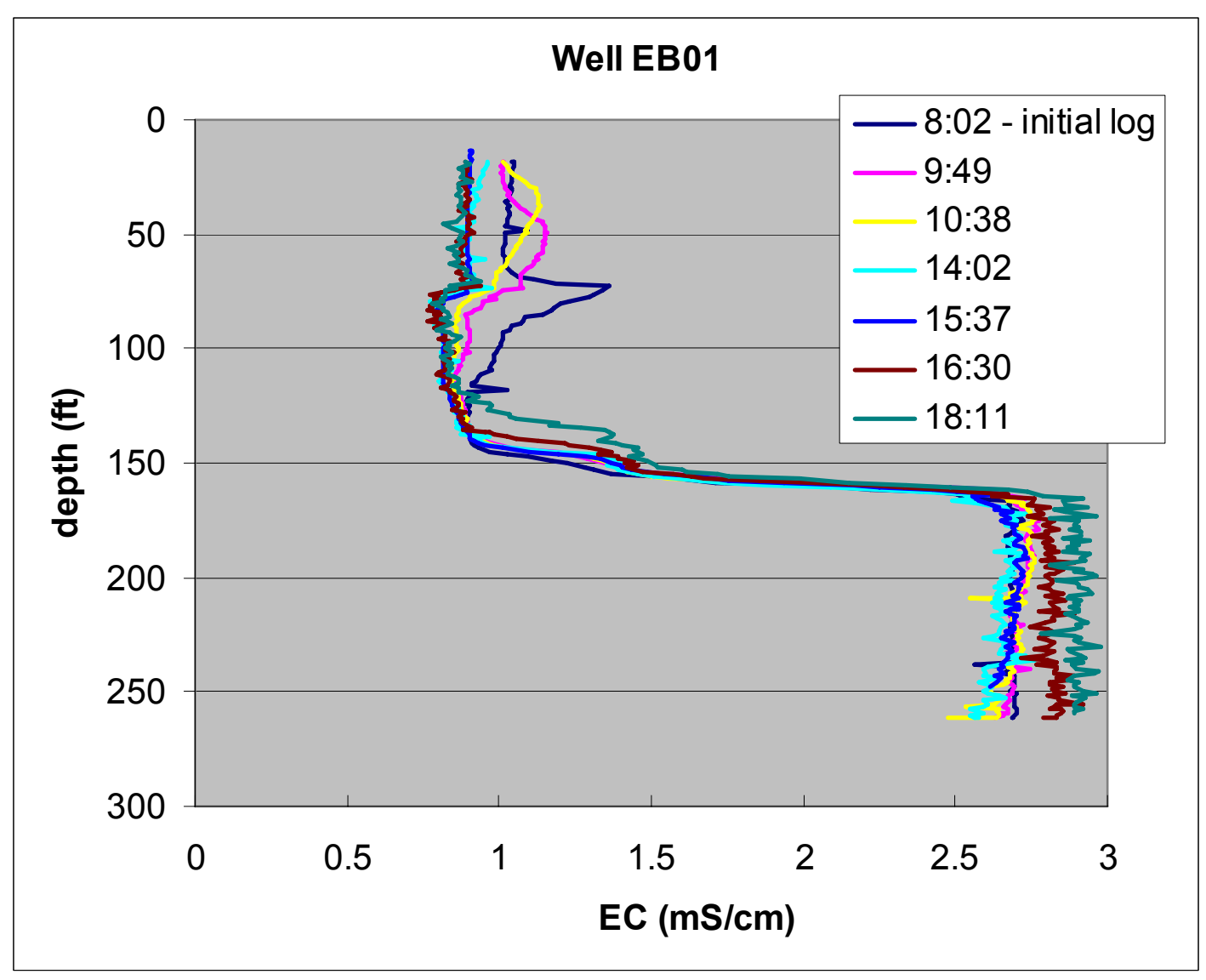

Figure 20. FEC logging profiles at open abandoned well EB-01 in East Bear Creek Unit. The times during which the logging took place are indicated in the legend. The water level in this well was initially at $18 \mathrm{ft}$ below the ground surface.

\subsection{Groundwater quality}

Regional groundwater quality is highly variable on lands to the east of the San Joaquin River with the best water quality being reported in areas served by shallow wells associated with recharge areas supplied by east-side tributaries such as the Merced River and Bear Creek with poorer water quality reported from deeper wells closer to the San Joaquin River. Bookman-Edmonston (2003, 2005), Schmidt (2005) and Quinn (2006) have published reports on groundwater quality that support this generalization. Water quality in the above- Corcoran semi-confined aquifer is affected by the regional flow system that is 
Table 1. Specifications for abandoned production wells (inactive, non-functional): well 11 (EB-01), well 12 (EB-02) and well 13 (EB-03) within the East Bear Creek Unit of the San Luis NWR.

Well \# 11 Location: T8S-R11E-Section 20H

Present Depth: 287 feet (based on T.V. survey)

Perforated interval: 60 to 287 feet (based on T.V. survey)

Yield: $1,716 \mathrm{gal} / \mathrm{min}$

Drawdown: 28 feet

Pumping Plant Efficiency: 47\%

Specific Capacity: $61 \mathrm{gal} / \mathrm{min}$ per foot of drawdown

Well potential based upon specific capacity: Good

Groundwater Electrical Conductivity: $2,953 \mathrm{uS} / \mathrm{cm}$

Shannon Pump Co. evaluation of well: Good well

Evaluation of T.V. Survey:

Static depth to water - 10 feet

Condition of casing and perforations - Encrusted perforations 60 to 118 feet, open and in good condition 120 to 220 feet, possible break in casing at $178-180$ feet.

Well \# 12 Location T8S-R11E-Section 20D

Present Depth: 185 feet (based on T.V. survey)

Perforated interval: 78 to 185 feet (based on T.V. survey)

Yield: $838 \mathrm{gal} / \mathrm{min}$

Drawdown: 75.2 feet

Pumping Plant Efficiency: $31 \%$

Specific Capacity: $11 \mathrm{gal} / \mathrm{min}$ per foot of drawdown

Well potential based upon specific capacity: Poor

Groundwater Electrical Conductivity: $1,871 \mathrm{uS} / \mathrm{cm}$

Shannon Pump Co. evaluation of well: Replace

Evaluation of T.V. Survey:

Static depth to water - 9 feet

Condition of casing and perforations - Heavy scale 34 - 79 feet, very encrusted perforations 79 feet to bottom

Well \# 13 Location T8S-R11E-Section 8R

Present Depth: 149 feet (based on T.V. survey)

Perforated interval: 86 to 149 (based on T.V. survey)

Yield: $1,218 \mathrm{gal} / \mathrm{min}$

Drawdown: 52.2 feet

Pumping Plant Efficiency: $62 \%$

Specific capacity: $23 \mathrm{gal} / \mathrm{min}$ per foot of drawdown

Well potential based upon specific capacity: Fair

Groundwater Electrical Conductivity: 3,214 uS/cm

Shannon Pump Co. evaluation of well: Replace

Evaluation of T.V. Survey:

Static depth to water -9 feet

Condition of casing and perforations - Possible breaks at 37 and 72 feet, hole in casing at 90 feet, break or very corroded joint at 97 feet, rough joint at 121 feet, very encrusted perforations 86 to 100 feet, moderate encrustation 100 to bottom 
influenced by recharge from local streams and surface water conveyances and drainage into the San Joaquin River to the west. Newer man-made channels which cut through sandy formations within the shallow groundwater aquifer may experience high rates of seepage. Older natural channels may seal over time as fine grained materials plug the interstices between sand grains and hence experience low rates of seepage. In the latter case, the rate of seepage is dictated by the permeability of the streambed rather than the permeability of the shallow aquifer.

Table 2 Comprehensive chemical analysis performed on the well water from the abandoned production wells 11 (EB-01), 12 (EB-02) and 13 (EB-03). The reported EC of 2,953 uS/cm in well 11 (EB-01) is consistent with the water quality obtained from FEC logging experiments. Ag and Aquatic STD - refers to water quality objectives for either agriculture or State of California receiving waters (Turner, 2001).

\begin{tabular}{|c|c|c|c|c|}
\hline \multicolumn{5}{|c|}{ (all values in $\mathrm{mg} / \mathrm{l}$ except where noted) } \\
\hline Constituent & Ag \& Aquatic STD & $\# 11$ & $\approx 12$ & $\# 13$ \\
\hline Aluminum & & 0.63 & $\$ 0.01$ & 0.95 \\
\hline Antimony & & $\$ .001$ & $\$ .001$ & $\$ .001$ \\
\hline Arsenic & 0.1 & $\$ .001$ & 0.009 & $\$ .001$ \\
\hline Barium & & 0,051 & 0.11 & 0.056 \\
\hline Beryllium & & $<.001$ & 4.001 & 4.001 \\
\hline Boron (ug/L) & 700 & 400 & $<100$ & $<100$ \\
\hline C'admium & 0.01 & 0.00083 & 41,00005 & 4,00003 \\
\hline Calcium & & 95 & 61 & 94 \\
\hline Chromium & 0.23 & 0.0046 & $\$ 0.001$ & 0.006 \\
\hline Copper & 0.029 & 0.032 & 0.13 & 0.013 \\
\hline Iron & 5 & 1.4 & 0.73 & 2.8 \\
\hline Lead & 0.011 & 0.0014 & $\$ .001$ & 0.001 \\
\hline Magnesium & & 33 & 27 & 36 \\
\hline Manganese & 0.2 & 0.71 & 0.64 & 0.63 \\
\hline Mercury $(u g / L)$ & 0.05 & 0.016 & 40.005 & 0,005 \\
\hline Molybdenum & 0.01 & 0.03 & 0.024 & 0.021 \\
\hline Nickel & 0.17 & 0.01 & 0.0032 & 0.0096 \\
\hline Potassium & & 4.0 & 4.0 & 4.0 \\
\hline Selenium & 0.005 & 40.0004 & None Detected & None Detected \\
\hline Silver & 0.037 & 4,001 & 4,001 & $\$, 001$ \\
\hline Sodium & & 493 & 269 & 551 \\
\hline Thallium & 0,063 & 4,001 & $\$ .001$ & $\$, 001$ \\
\hline Uranium & $\$$ & 0.012 & 0.015 & 0.018 \\
\hline Zinc & 0.38 & 0.032 & 0.0075 & 0.031 \\
\hline Ammonia as $\mathrm{N}$ & 4.2 & 0,08 & 0.17 & $\triangle 0.05$ \\
\hline Chlonide & 106 & 678 & 89.6 & 684 \\
\hline Cyanide (ug/L) & 5.2 & 10 & 10 & 10 \\
\hline Fluoride & 1 & 0.31 & 0.18 & 0.30 \\
\hline Nitrate +Nitrite as $\mathrm{N}$ & & 40.05 & $\triangle 0.05$ & $\$ 0.05$ \\
\hline Sulfate & & 188 & 127 & 262 \\
\hline TDS & 450 & 1640 & 982 & 1650 \\
\hline Total Phosphons & & 0,07 & 0.10 & 0,07 \\
\hline $\mathrm{EC}$ (umhos/cm) & 700 & 2953 & 1871 & 3214 \\
\hline $\mathrm{pH}$ (pH units) & & 7.68 & 7.56 & 7,60 \\
\hline Gross Alpha (pCi/L) & & 8.63 & 10.6 & 5.79 \\
\hline
\end{tabular}


Table 3 Comprehensive chemical analysis performed on the well water from shallow production wells PW-03-29 within the East Bear Creek Unit and PW-03-32 within the West Bear Creek Unit during 2003. The wells are $3 / 4$ mile apart. The reported ECs of $1,320 \mathrm{uS} / \mathrm{cm}$ and $822 \mathrm{uS} / \mathrm{cm}$ respectively are representative of the near surface aquifer. Agricultural and Aquatic Life refer to water quality objectives for either agriculture or State of California receiving waters (Sherer, 2003).

\begin{tabular}{|c|c|c|c|c|c|}
\hline \multicolumn{6}{|c|}{$\begin{array}{c}\text { Groundwater Quality Summary } \\
\text { U.S. Bureau of Reclamation } \\
\text { East Bear Creek } \\
\end{array}$} \\
\hline Constituent & PW-03-29 & PW-03-32 & $\begin{array}{l}\text { Primary } \\
\mathrm{MCL}\end{array}$ & $\begin{array}{c}\text { Secondary } \\
\mathrm{MCL}\end{array}$ & $\begin{array}{c}\text { Aquatic } \\
\text { Life/Agricultural }\end{array}$ \\
\hline Aluminum & $<50$ & $<<50$ & 1000 & 200 & \\
\hline Antimony & $<2.0$ & $<2.0$ & 6 & & \\
\hline Arsenic & 14 & $<2.0$ & 10 & & 100 \\
\hline Barium & 74 & 140 & 1000 & & \\
\hline Beryllium & $<1.0$ & $<1.0$ & 4 & & \\
\hline Boron (total) & 270 & 280 & & & 700 \\
\hline Cadmium & $<1.0$ & $<1.0$ & 5 & & 10 \\
\hline Calcium & 41400 & 51600 & & & \\
\hline Chromium & $<2.0$ & $<2.0$ & 50 & & 230 \\
\hline Copper & $<2.0$ & 2.7 & 1300 & 1000 & 29 \\
\hline Iron & 1800 & $<50$ & & & 5000 \\
\hline Lead & $<1.0$ & $<1.0$ & 15 & & 11 \\
\hline Magnesium & 25300 & 19700 & & & \\
\hline Manganese & 2500 & 180 & & & 200 \\
\hline Mercury & $0.0026^{a}$ & $0.0063^{\mathrm{a}}$ & 2 & & 0.05 \\
\hline Molybdenum (total) & 6.9 & 7.1 & & & 10 \\
\hline Nickel & $<2.0$ & $<2.0$ & 100 & & 170 \\
\hline Potassium & 1900 & 2400 & & & \\
\hline Selenium & $<0.4$ & 0.7 & 50 & & 5 \\
\hline Silver & $<1.0$ & $<1.0$ & & & 37 \\
\hline Sodium & 179000 & 88100 & & & \\
\hline Thallium & $<1.0$ & $<1.0$ & 2 & & 63 \\
\hline Uranium & $<5.0$ & 14 & & & \\
\hline Zinc & 6.3 & 10 & & & 380 \\
\hline Ammonia as $\mathrm{N}$ & 183 & $<50$ & & & 4200 \\
\hline Chloride & 240000 & 100000 & & & 106000 \\
\hline Cyanide & $<5.0$ & $<5.0$ & 150 & & 5200 \\
\hline Fluoride & 460 & 230 & & & 1000 \\
\hline Nitrate + Nitrite as $\mathrm{N}$ & $<100$ & 850 & 10000 & & \\
\hline Sulfate & 110000 & 75000 & & & \\
\hline TDS & 780000 & 500000 & & & 450000 \\
\hline Total Phosphorus & 750 & 80 & & & \\
\hline Gross Alpha (pCi/L) & $<2.00$ & 8.10 & 15 & & \\
\hline $\mathrm{pH}$ (pH units) & 6.90 & 7.11 & & & \\
\hline $\mathrm{EC}$ (us/cm) & 1320 & 822 & & & 700 \\
\hline Turbidity (NTU) & 104 & 0.7 & & & \\
\hline
\end{tabular}


The groundwater data provided in Tables 1, 2 and 3 show that water quality in wells 11 (EB-01), 12 (EB02) and 13 (EB-03) is generally better in the upper $50 \mathrm{ft}$ of the aquifer than in the screened interval of the three wells. For well 29, which is located close to well 11 (EB-01) within the East Bear Creek Unit (tested using the FEC logging technique), the EC after 15 minutes of pumping was $980 \mathrm{uS} / \mathrm{cm}$. As previously reported, the EC at the depth of the well screen in well 11 (EB-01) is over $2,900 \mathrm{uS} / \mathrm{cm}$. This suggests that pumping of the shallow groundwater aquifer will yield consistently better quality water. However shallow pumping has the disadvantage of being constrained by rate of withdrawl owing to well induced drawdown and a requirement that a head of water remain above the pump bowls. Low well yield constrained by the horizontal transmissivity of the shallow aquifer would require a large well field which would significantly increase the cost of pumped water compared to fewer wells pumping from greater depths and at rates more than 10 times those of the shallow aquifer wells.

Table 4. Water quality data comparison between groundwater and surface water sources (Source : Shipp, 2004)

\begin{tabular}{|c|c|c|c|c|}
\hline $\begin{array}{l}\text { Groundwater Well/ } \\
\text { Surface Water }\end{array}$ & $\begin{array}{c}\text { Pumping duration } \\
(\text { mins })\end{array}$ & $\begin{array}{l}\text { Temperature } \\
(\operatorname{deg} C)\end{array}$ & $\begin{array}{l}\text { Discharge } \\
\text { (gals) }\end{array}$ & $\begin{array}{c}\text { EC } \\
(\mathrm{uS} / \mathrm{cm})\end{array}$ \\
\hline $\begin{array}{l}\text { Island C Canal } \\
\text { (west-side) }\end{array}$ & 0 & 25 & 0 & 550 \\
\hline San Joaquin River & 0 & 24 & 0 & 1,215 \\
\hline Pumped well PW-03-29 & $\begin{array}{c}41 \\
118 \\
930\end{array}$ & $\begin{array}{l}21.7 \\
19.5 \\
19.3\end{array}$ & $\begin{array}{c}2,624 \\
7,552 \\
59,520\end{array}$ & $\begin{array}{l}950 \\
935 \\
980\end{array}$ \\
\hline Pumped well PW-03-32 & $\begin{array}{c}46 \\
500 \\
\end{array}$ & $\begin{array}{l}18.5 \\
18.8 \\
\end{array}$ & $\begin{array}{c}2,994 \\
32,000 \\
\end{array}$ & $\begin{array}{l}1,340 \\
1,380 \\
\end{array}$ \\
\hline
\end{tabular}

\subsection{Groundwater Pumping}

Pump tests conducted by Shipp and Sherer (Shipp, 2004) were evaluated to determine the suitability of the shallow groundwater aquifer for providing water supply to the East Bear Creek Unit. Graphs illustrating the results of the various pump tests provide information on the specific capacity of the wells, the maximum drawdown of the water level during pumping, the total pump lift, measured flow rate and allow the estimation of the cost of groundwater pumping based on the cost of power.

The pump tests were carried out using a Berkeley 7.5 hp pump operating at flow rates of between 63 and $65 \mathrm{gals} / \mathrm{min}$ for the duration of the experiment. Pumpage was measured with a totalizing meter and discharged to a canal approximately $50 \mathrm{ft}$ away. Pumping continued until the rate of drawdown diminished to less than $0.01 \mathrm{ft} / \mathrm{hr}$. The East Bear Creek Unit well PW-03-29 was pumped for 1,300 minutes whereas well PW-03-32 approximately $3 / 4$ mile away directly across the San Joaquin River in the West Bear Creek Unit, was pumped for 920 minutes (Shipp, 2004). Drawdown data was obtained from pressure transducers located in nearby observation wells reporting to a multi-channel datalogger. The data recording interval increased with time according to a logarithmic scale. Specific conductivity measurements were measured at the beginning of the pump tests and at intervals during the pump test to 
check if dewatering the shallow aquifer would lead to interception of poorer quality water. These results are presented in table 4. A groundwater sample was taken during the pump tests and submitted to an analytical laboratory for a full chemical analysis of dissolved constituents and turbidity. These data were presented in Table 3 and can be contrasted with the data for wells 11 (EB-01), 12 (EB-02) and 13 (EB-03) that were shown in Table 2, taken within the deep, above-Corcoran aquifer and indicative of formation water adjacent to the well screen of each abandoned well.

\subsubsection{Pump test theory}

Aquifer pump tests were performed on observation wells OW-03-27 and OW-03-28, located adjacent to the pumping wells PW-03-29 in the East Bear Creek Unit and on observation well OW-03-30 located adjacent to PW-03-32 in the West Bear Creek Unit (Figure 11). The saturated interval of wells OW-0327 and OW-03-28 were $19 \mathrm{ft}$ and $15 \mathrm{ft}$ respectively - well OW-03-27 was $20 \mathrm{ft}$ from the pumped well PW-03-29 and well OW-03-28 was $38 \mathrm{ft}$ distant. The saturated interval of well OW-03-30 was $20 \mathrm{ft}$ and the well was located $21 \mathrm{ft}$ from the pumped well PW-03-32. A review of site hydrogeology suggested that the groundwater aquifer within which the aquifer pump test was conducted was unconfined and this assumption was used in calculating aquifer hydraulic parameters.

Aquifer hydraulic parameters were estimated using a number of common test methods using computer software AquiferTest 2000 (Shipp, 2004) and are presented in Table 5. Methods developed by Theis (1935), Cooper-Jacob (1946), Neuman (1975) and Moench (1993) all yield slightly different results. Averages of all relevant methods are usually used to determine aquifer hydraulic parameters. An overview of the theory of aquifer parameter estimation methods is provided by the User's Manual for the AquiferTest2000 computer software (Waterloo HydroGeologic, 2000) which is summarized below :

Table 5. Results of aquifer tests performed by Shipp and Sherer in July 2003 as part of a geologic assessment in support of a canal realignment project (Shipp, 2004).

\begin{tabular}{|l|c|c|c|c|c|c|}
\hline Well ID & Parameter & Theis & $\begin{array}{c}\text { Cooper- } \\
\text { Jacob }\end{array}$ & Neuman & Moench & Average \\
\hline East Side & $\mathrm{T}\left(\mathrm{ft}^{2} / \mathrm{min}\right)$ & 2.830 & 4.500 & 1.910 & 0.639 & 2.50 \\
OW-03-27 & $\mathrm{K}(\mathrm{ft} / \mathrm{min})$ & 0.150 & 0.239 & 0.102 & 0.0340 & 0.131 \\
& $\mathrm{Sy}$ & - & - & 0.00010 & 0.0638 & 0.030 \\
& & & & & & \\
\hline & & & & & & \\
OW-03-28 & $\mathrm{T}\left(\mathrm{ft}^{2} / \mathrm{min}\right)$ & 4.220 & 2.790 & 2.760 & 0.681 & 2.60 \\
& $\mathrm{~K}(\mathrm{ft} / \mathrm{min})$ & 0.283 & 0.187 & 0.0185 & 0.0457 & 0.175 \\
& $\mathrm{Sy}$ & - & - & 0.0000053 & 0.0681 & 0.030 \\
& & & & & & \\
\hline & & & & & & \\
\hline West side & $\mathrm{T}\left(\mathrm{ft}^{2} / \mathrm{min}\right)$ & 5.280 & 4.240 & 1.880 & 0.589 & 3.10 \\
& $\mathrm{~K}(\mathrm{ft} / \mathrm{min})$ & 0.263 & 0.211 & 0.0935 & 0.0273 & 0.153 \\
& $\mathrm{Sy}$ & - & - & 0.00009 & 0.589 & 0.300 \\
& & & & & & \\
\hline \multirow{2}{*}{ OW-03-31 } & $\mathrm{T}\left(\mathrm{ft}^{2} / \mathrm{min}\right)$ & 4.060 & 3.890 & 2.310 & 0.691 & 2.90 \\
& $\mathrm{~K}(\mathrm{ft} / \mathrm{min})$ & 0.229 & 0.220 & 0.130 & 0.0390 & 0.162 \\
& $\mathrm{Sy}$ & - & - & 0.0010 & 0.069 & 0.040 \\
& & & & & & \\
\hline
\end{tabular}


In groundwater aquifers such as that below the East Bear Creek Unit characteristics are non-ideal, meaning they display characteristics of both unconfined and confined aquifers. The layer of silty clay that was shown from the CPT logs to be present above the first shallow aquifer acts as a leaky confining layer. It is not homogeneous hence in some areas the groundwater system behaves more like an unconfined system than a confined system. In these circumstances performing aquifer parameter estimation using a variety of methods provides a useful range of values that most likely bracket conditions in the field. Hence in Table 5 a simple average of the four aquifer methods can yield a reasonable first estimate of aquifer transmissivity, hydraulic conductivity and storativity.

The assumptions made by each of the methods for validity are as follows :

- The aquifer is confined and has an "apparent" infinite extent

- the aquifer should be homogeneous, isotropic and of uniform thickness over the area influenced by pumping

- the piezometric surface was horizontal prior to pumping

- the well is pumped at a constant rate

- the well is fully penetrating

- water removed from storage is discharged instantaneously with a decline in head

- the well diameter is small and well storage in negligible

- the values of " $u$ " are small - typically $u<0.01$

\subsubsection{Theis Method}

The Theis method (Theis, 1935) is an analytical solution for confined aquifer conditions that describes drawdown, measured as hydraulic head $(\mathrm{h})$ at any radial distance $(\mathrm{r})$ from the pumped well at any time (t) after the initiation of pumping.

$$
\begin{aligned}
& s(r, t)=\frac{Q}{4 \pi T} \int_{t}^{\infty} e^{-u} \frac{d u}{u} \\
& u=\frac{r^{2} S}{4 T t}
\end{aligned}
$$

Where: $\quad \mathrm{s}=\operatorname{drawdown}(\mathrm{ft})$

$\mathrm{Q}=$ pumping well discharge (gpm)

$\mathrm{T}=$ coefficient of transmissivity $(\mathrm{gpd} / \mathrm{ft})$

$\mathrm{S}=$ storativity (dimensionless)

$\mathrm{u}=$ analytical parameter

An integral, known as a well function $[W(u)]$, which relies on the definition of " $\mathrm{u}$ " provided above can be represented by an infinite Taylor series, which takes the following form :

$$
W(u)=0.5772-\ln (u)+u-\frac{u^{2}}{2.2 !}+\frac{u^{3}}{3.3 !}-\ldots .
$$

Using this function $\mathrm{W}(\mathrm{u})$ the equation (above) becomes : 


$$
s=\frac{Q}{4 \pi T} W(u)
$$

If a graph is constructed of $\mathrm{W}(\mathrm{u})$ along the ordinate and the $1 / \mathrm{u}$ along the abscissa as a log- log plot the result is known as a Theis curve. Field data are typically plotted as $t / r^{2}$ along the $\mathrm{x}$-axis against $\mathrm{s}$ along the y axis. Aquifer parameters are determined by matching the observed data to the standard Theis curve. The assumptions for validity that were described above are not fully met by the field conditions in the East Bear Creek Unit. Pumping tests typically should be performed for longer than 24 hours to be valid in order to allow for removal of water around the well casing. Determination of an avcurate estimate of aquifer transmissivity depends on being able to identify any well casing storage effect and whether a recharge boundary has been encountered early on in the pump test.

Theis plots are presented in Appendix Figures A1 and A5. In both plots a match point is selected where there is maximum overlap between the observed data and the Theis curve. Recharge and impervious boundaries can cause the real data to deviate significantly from the theoretical Theis curve. This deviation is observed in neither of Figures A1 and A5 suggesting an absence of these effects for the duration of the aquifer test.

Hydraulic conductivity estimates made using curve matching and the Theis method range between 216 and $408 \mathrm{ft} /$ day. Transmissivity rates estimates are 4075 and $6077 \mathrm{ft}^{2} / \mathrm{day}$. Since the Theis method is relevant to ideal confined aquifers - these results suggest high transmission rates of groundwater within the near-surface aquifer layer within which the test was conducted.

\subsubsection{Cooper and Jacob Method}

The Cooper and Jacob (1946) method was developed as a simplification of the Theis technique that is valid for greater pump test periods and observation wells located closer to the pumped well. In the analytical solution the Taylor series (described above) is truncated eliminating the relevance of the measured values taken at times close to the onset of pumping. The Theis equation is therefore simplified to the following :

$$
s=\left[\frac{2.3 Q}{4 \pi T}\right] \log _{10}\left[\frac{2.25 T t}{S r^{2}}\right]
$$

Where : $\mathrm{s}=$ drawdown $(\mathrm{ft})$

If the limiting conditions are met and sufficient time has elapsed - the equation above plots as a straight line on semi-log paper.

Transmissivity and storativity are calculated from the following equations :

$$
\begin{aligned}
& T=\frac{2.3 Q}{4 \pi \Delta s} \\
& S=\frac{2.25 T t_{0}}{r^{2}}
\end{aligned}
$$

Cooper and Jacob (1946) plots are provided in Figures A2 and A6. Figure A2 for observation well OW03-27 shows a classical example of the effect of slow drainage to the well which typically occurs whenever there is a marked difference between the vertical and horizontal hydraulic conductivity in the 
aquifer sediments allowing water to move more rapidly in a horizontal direction than a vertical direction. When pumping commences vertical flow is slight but increases over time as gradients increase and the cone of depression surrounding the well widens. The slope of the curve deviates approximately 10 minutes into the test - the shape of which suggests it is not caused by well casing storage. The temporary excursion below the straight time-drawdown curve converges with increased time. This condition tends to be more pronounced where the top layer of finer grained sediments is greater in thickness and contains lower permeability materials. The Cooper and Jacob (1946) method produced higher estimates of hydraulic conductivity and transmissivity than the Theis method hydraulic conductivity was $344 \mathrm{ft} /$ day and transmissivity was $6,460 \mathrm{ft}^{2} /$ day.

In Figure A6 for well OW-03-28 the Cooper and Jacob (1946) plot deviates at approximately 3 minutes into the well test and provides evidence of recharge to the aquifer within the zone of influence of the well. The change in slope is not likely due to well casing because this effect commonly occur very soon after the onset of pumping (approximately $1 / 10^{\text {th }}$ minute) (Driscoll, 1995). The fact that the timedrawdown plot maintains a downward trajectory suggests that the pumping rate exceeds the natural rate of recharge from the watercourses in the vicinity of the pumped well. Vertical recharge can be ruled out since the area is not irrigated. The San Joaquin River and Bear Creek both are likely sources of recharge to the pumped well. Shipp (2004) estimated the transmissivity of both portions of the curve for well OW-03-28 - the first segment of the curve provided a value of $4,016 \mathrm{ft}^{2} /$ day $\left(2.76 \mathrm{ft}^{2} / \mathrm{min}\right)$ and the second portion of the curve a value of $9,187 \mathrm{ft}^{2} /$ day $\left(6.38 \mathrm{ft}^{2} / \mathrm{min}\right)$. Shipp (2204) suggested that because the values derived from the two different slopes were not that different - the recharge boundary does not greatly influence the drawdown in the observation well. Since no significant changes in slope occurred in the later stages of the pumping test Shipp (2204) concluded that the cone of depression had not encountered the San Joaquin River. He suggested using the initial portion of the curve as the more representative of the aquifer. Hydraulic conductivity of well 28 was estimated to be $269 \mathrm{ft} /$ day.

The Cooper-Jacob (1946) method produces higher values for aquifer properties for aquifer transmissivity and hydraulic conductivity for observation well OW-03-28 than for observation well OW-03-27 - the Theis method produces the opposite result. The Cooper-Jacob (1946) method is a simplification of the Theis method and therefore possibly more prone to error when conditions deviate from a strictly confined aquifer system.

\subsubsection{Neuman Method}

The Neuman (1975) method was developed specifically to analyze pumping tests in unconfined aquifers. As was previously suggested - groundwater aquifers such as that below the East Bear Creek Unit typically demonstrate both confined and unconfined aquifer characteristics. Techniques that emulate drawdown response for unconfined systems such as the Neuman method can be contrasted with the Theis and Cooper/Jacob method to determine a realistic range of aquifer parameters that better describe the likely spatial heterogeneity of the groundwater system.

Plotting drawdown against time on logarithmic paper produces and inflected curve with three district segments : (1) a steep segment at early time; (2) a flat segment at intermediate time; and (3) a somewhat steep segment at later time. Analysis of the three segments reveals storage characteristics of the aquifer. The early segment describes instantaneous release of water from storage. The intermediate segment typically suggests a secondary source of water which is released from the aquifer after a period of delay. When this secondary source has been depleted (delayed yield has been fully exploited) the timedrawdown curve becomes steep once again. Hence the Neuman method has utility in providing information on some of the surface hydrology of the landscape and how it might interact with the local groundwater system. 
The equation developed by Neuman (1975) which describes drawdown in an unconfined aquifer has the following form :

$$
s=\frac{Q}{4 \pi T} W\left(u_{A}, u_{B}, \beta\right)
$$

Where: $W\left(u_{A}, u_{B}, \beta\right)=$ unconfined well function

$$
\begin{aligned}
u_{A} & =\frac{r^{2} S}{4 T t} \text { (Type A curve for early time) } \\
u_{B} & =\frac{r^{2} S}{4 T t} \text { (Type B curve for later time) } \\
\beta & =\frac{r^{2} K_{v}}{D_{2} K_{h}} \\
\mathrm{D} & =\text { initial saturated thickness }
\end{aligned}
$$

Two sets of curves are used : Type-A curves for early drawdown when water is released from elastic storage and Type-B curves for later drawdown when the effects of gravity drainage become more significant.

Hydraulic conductivity is determined from the relation : $K_{h}=T / D$

Vertical hydraulic conductivity is determined using : $K v=\frac{\beta D^{2} K_{h}}{r^{2}}$

Neuman plots are presented in Appendix Figures A3 and A7. In both plots a match point is selected where there is maximum overlap between the observed data and the Theis curves. Recharge and impervious boundaries can cause the real data to deviate significantly from the theoretical Theis curves. Hydraulic conductivity estimates made using curve matching range between 147 and $27 \mathrm{ft} /$ day for the two observation wells OW-03-27 and OW-03-28 respectively. Transmissivity rates estimates are 2,750 and $3,974 \mathrm{ft}^{2} /$ day. Since the Neuman method is suited to ideal unconfined aquifers - these results suggest somewhat lower values of hydraulic conductivity for groundwater within the near-surface aquifer layer than was determined in either the Theis (1935) or Cooper Jacob (1946) methods. The Neuman method shows a match at low values of $\mathrm{S}$ - close to 0.01 . Aquifer specific yields computed with this method are low - especially for the observation well OW-03-28 which was assigned a value of $5.3 \mathrm{e}^{-06}$, a value that is more indicative of a confined aquifer system.

\subsubsection{Moench Method}

The Moench (1993) method is an extension of the Neuman method which permits analysis of delayed yield effects in unconfined aquifers. The technique can be extended to confined conditions where $\mathrm{D}$ is the thickness of the saturated zone. Previous analytical solutions assume instantaneous drainage from the unsaturated zone (Theis, 1935; Neuman, 1972, 1974) and tend to underestimate the specific yield (Moench, 1995). The assumption that drainage from the unsaturated zone declines exponentially with time, tend to overestimate drawdown at early-times and underestimate it during late times.

The general solution developed by Moench for drawdown (dimensionless drawdown $h_{D}$ ) is given by : 


$$
\mathrm{h}_{\mathrm{D}}\left(\gamma, \beta, \sigma, z_{D}, t_{D}\right)=h_{D T}+\Delta h_{D H}+\Delta h_{D N}
$$

Where : $\quad h_{d}=\frac{4 \pi K D}{Q}\left(h_{0}-h_{f}\right)$

And : $\quad \gamma=\alpha b S_{y} / K_{z}$ - dimensionless fitting parameter; $\alpha$ is an empirical constant

$$
\begin{aligned}
& \beta=\left(r^{2} K_{v}\right) /\left(D^{2} K_{h}\right) \\
& \sigma=S / S_{y} \\
& z_{D}=b / D \text { - dimensionless depth of the piezometer } \\
& \mathrm{b}=\text { aquifer thickness (confined wells) or depth from water table to bottom of well screen } \\
& \text { (unconfined aquifers) } \\
& t_{D}=\mathrm{Tt} / \mathrm{r}^{2} \mathrm{~S}-\text { dimensionless time } \\
& h_{D T}=\text { Theis solution for a well in a confined aquifer } \\
& \Delta h_{D H}=\text { deviation from the Theis solution due to a partially penetrating well in a confined aquifer } \\
& \Delta h_{D N}=\text { deviation from the Theis solution due to the effects of the free surface (Neuman } \\
& \text { component) }
\end{aligned}
$$

For confined aquifers the Moench (1993) method uses the first two components of the equation above to account for the confined aquifer conditions and for a partly penetrating well. For confined conditions and fully-penetrating pumping and observation wells - the Moench method uses the same analytical solution as the Theis method. For unconfined conditions and fully-penetrating pumping and observation wells the analytical solution is the same as the Neuman method. The Moench solution uses dimensionless parameters for the type curves where $\log \left(h_{d}\right)$ on the ordinate is plotted against $\log \left(t_{d y}\right)$ on the abscissa. The data are plotted as $\log (\mathrm{s})$ on the ordinate against $\log \left(\mathrm{t} / \mathrm{r}^{2}\right)$ on the abscissa.

Moench plots are presented in Appendix Figures A4 and A8. The well time drawdown observations are bracketed by the two theoretical Theis curves for both observation wells. For observation well OW-0327 the observed data seems to fit the confined Theis curve more closely whereas observation well OW03-28 is closer to the Neuman curve. Recharge and impervious boundaries can cause the real data to deviate significantly from the theoretical Theis curves. Hydraulic conductivity estimates made using curve matching range between 49 and $66 \mathrm{ft} /$ day for the two observation wells OW-03-27 and OW-03-28 respectively. Transmissivity rates estimates are much closer at 980 and $920 \mathrm{ft}^{2} /$ day. Moench estimates for hydraulic conductivity and aquifer transmissivity are generally lower than the estimates for the other methods. The specific yield/storativity estimates for both observation wells are identical and equal to 0.03 - a relatively low yield for an unconfined aquifer and high number for a confined aquifer. This result is similar to that for observation well OW-03-31 in the West Bear Creek Unit.

\subsection{Groundwater Resource Evaluation}

The volume of groundwater in storage can be estimated using the average estimated aquifer thickness and the estimated specific yield of the aquifer (Table 5). Well logs for the deep abandoned wells were not available for the East Bear Creek Unit nor were any of the wells screened to penetrate the full extent of the above-Corcoran Clay aquifer. Well logs were developed from the CPT logging experiments however the cone truck was only able to achieve depths of between $70-100 \mathrm{ft}$ before the truck started lifting - because of high sliding friction on the cone penetrometer. Exceeding the applied load can cause a rod to stick or, if the cone truck is pushed out of alignment, can cause bent or damaged rods. 
Using the areal extent of the East Bear Creek Unit of 4,000 acres and an average aquifer depth derived by taking the average depth of both sand and sand to silty-sand layers between the surface and the $50 \mathrm{ft}$ depth from the CPT plots in Figures 13 - 17. The West Bear Creek Unit CPT logs were not considered in this determination. The mean depth of sand aquifer for the CPT logs analyzed is $20 \mathrm{ft}$ (for those CPT logs discontinued after $35 \mathrm{ft}$ - the mean depths in the interval from $35 \mathrm{ft}$ to $50 \mathrm{ft}$ were derived from Figure 13) and the average depth of material described as sand to silty-sand was estimated at $15 \mathrm{ft}$. The sand to siltysand layer was assumed to have $2 / 3$ of the hydraulic conductivity of the sand layer - hence the total effective depth of aquifer was reduced to an estimated $30 \mathrm{ft}$. Tables 1 and 2 suggest that a $50 \mathrm{ft}$ depth may be the limit of good quality water.

From the analysis and assumptions provided above the amount of groundwater yield available is estimated at 3,600 acre-ft/ft of drawdown. A distributed well field pumping for 6 months per year should be able to supply sufficient water for Level 4 requirements without excessive well drawdown based on the analysis of aquifer properties. However, sustainable exploitation of this groundwater resource depends on the rate of groundwater recharge derived from deep percolation of irrigated water and seepage from canals and conveyance structures that border the East Bear Creek Unit.

\subsection{Groundwater levels and aquifer safe yield}

Groundwater level data have not been routinely collected within the East Bear Creek Unit hence there are no hydrographs to show trends in groundwater levels over time. The maximum rate of aquifer groundwater pumping that does not exceed the recharge is known as the safe yield. Recharge rates to the aquifer are a combination of effective rainfall, or seepage from nearby water conveyances such as Bear Creek, Bravel Slough and the San Joaquin River. Hence future shallow pumping of the groundwater aquifer below the East Bear Creek Unit will be limited by surface recharge and by lateral movement of groundwater into the Unit from these conveyances. Data analyzed in this report shows reasonable shallow aquifer transmissivity to allow the design of a functional well field. Groundwater recharge from the surface is restricted by the presence of a surface layer that is high in clay and silty materials which would limit the likely success of deliberate recharge through infiltration galleries and a program of water banking. Such a scheme might be wasteful of water given that water that percolates beyond the shallow layers will mix with the lower quality deeper within the above-Corcoran aquifer - reducing its utility. Water stored in aquifers that are subject to high water tables also can lose water through direct evaporation from the water table.

In order to estimate what portion of the potential well yield might be pumpable on an annual basis an estimate was made of potential exchange between the three conveyances Bear Creek, Bravel Slough and the San Joaquin River and the shallow groundwater aquifer. Earlier studies of groundwater accretions into the San Joaquin River in the vicinity of Salt Slough by the USGS have produced estimates of 1-2 $\mathrm{cfs} / \mathrm{mile}$. Although the gradients induced by wells pumping the aquifer in hydraulic contact with the San Joaquin River will likely compare to drainage gradients - current flow along the San Joaquin River upstream of Salt Slough is mostly the result of groundwater accretions and canal spills from agricultural and wetland operations and amounts to less than $10 \mathrm{cfs}$ during the late summer months. Bear Creek is not gauged but also tends to experience seasonal low flow during the late summer months. Aquifer recharge rates from these conveyances along are assumed to be no greater than $0.25 \mathrm{cfs} / \mathrm{mile}$. From Figure $21-$ the total length of conveyance structures hydraulically connected to the East Bear Creek Unit sum to 10 miles. Using the $0.25 \mathrm{cfs} / \mathrm{mile}$ estimate this amounts to a potential recharge rate to a well field within the East Bear Creek Unit of $5 \mathrm{cfs}$. If sustained over a year this amounts to 3,613 acre-ft/year - approximately $40 \%$ of the annual Level II water requirement for the East Bear Creek Unit of 8,863 acre-ft and 27\% of the annual Level IV water requirement of 13,295 acre-ft.

A different approach might be to assume all recharge to be provided upslope and to the east of the East Bear Creek Unit. The slope of the water table can be assumed to follow the land surface and would be in 
the vicinity of 3-5 $\mathrm{ft} / \mathrm{mile}$ or a gradient of about 7\%. Typical hydraulic conductivity of the aquifer material has been previously reported in the vicinity of $0.15 \mathrm{ft} /$ minute or in the range of $1,000-1,500$ gals/day- $\mathrm{ft}^{2}$. If the shallow aquifer is, on average about $20 \mathrm{ft}$ deep and the transmissivity is $20,000-$ 30,000 gals/day- $\mathrm{ft}$ - then assuming an east-side boundary of $4 \mathrm{~km}$ along the north-east boundary of the East Bear Creek Unit, the previously calculated gradient of $0.07 \mathrm{ft} / \mathrm{ft}$ - this results in a recharge of 17-25 acre-ft/day or 6,200 - 9,400 acre-ft per year or between $47 \%$ and $70 \%$ of the East Bear Creek Unit water requirements. This assumes that the mean gradient of $4 \mathrm{ft} / \mathrm{mile}$ is sustained over the course of the year.

However, not all of this yield can be recovered by groundwater pumping - this depends of the configuration of the well field and the rate of pumping. It is also conceivable that groundwater gradients might decline in the winter months as water levels rise in the San Joaquin River and the other stream conveyances. If only $50 \%$ of this potential yield were recoverable - this would amount to between $24 \%$ and $35 \%$ of the annual Level IV supply requirements.

Although both analyses are based on a number of simplifying assumptions it is clear that there is likely insufficient groundwater recharge to the aquifer beneath the East Bear Creek to provide full Level IV supply. However it is highly likely that this groundwater resource might provide between $17 \%$ and $35 \%$ of the annual Level IV requirements.

Limitations to the analysis based on stream-aquifer interaction are the lack of flow data in the relevant reaches of the San Joaquin River and Bear Creek - compounded by the fact that some of the flow observed in these conveyances during summer months may in fact be river accretions from the groundwater aquifer along the same flow path. During the late summer when flows within East Bear Creek and the San Joaquin River are at their lowest level and when seasonal wetlands are flooding pumping of the groundwater aquifer in East Bear Creek may potentially eliminate flow in either or both of these conveyances. A similar phenomenon has occurred further up the San Joaquin River at Gravelly Ford where groundwater pumping of the underlying aquifer has eliminated all flow in the River past this point. Once rainfall occurs and river and stream stage rises in response to rainfall-runoff events however the groundwater aquifer should be able to recover during average water years. The assumptions made in this analysis can only be checked by monitoring and by the deployment of monitoring stations upstream and downstream along the San Joaquin River and East Bear Creek adjacent to the East Bear Creek Unit. If this assessment continues to a feasibility stage - it is a recommendation of this report that gauging stations be deployed at the upstream and downstream points of each reach adjacent to the East Bear Creek Unit.

Limitations to the analysis of aquifer recharge based on upslope regional groundwater gradients assumes that no water is lost to the surface water conveyances which can act like interceptor drains and may siphon off some of the potential aquifer safe yield. The analysis also assumes that an average groundwater gradients of $4 \mathrm{ft} / \mathrm{mile}$ is sustained over the year. Since groundwater flow is the product of yield and aquifer transmissivity - a reduction in effective cross-sectional area of flow due to groundwater interception can reduce sustainable yield.

If shallow groundwater pumping were chosen as an option to supply a portion of the 13,295 acre-ft of Level 4 water required for the East Bear Creek Unit annually - the well field would most likely comprise a large number of wells pumping at relatively low volumes. Management of such a system, combined with the capital cost of a large number of installations would likely make such a system somewhat expensive compared to the cost of a smaller number of high yielding production wells, pumping from deeper in the aquifer. However, poor water quality limits further exploitation of the deep, aboveCorcoran, semi-confined aquifer. 


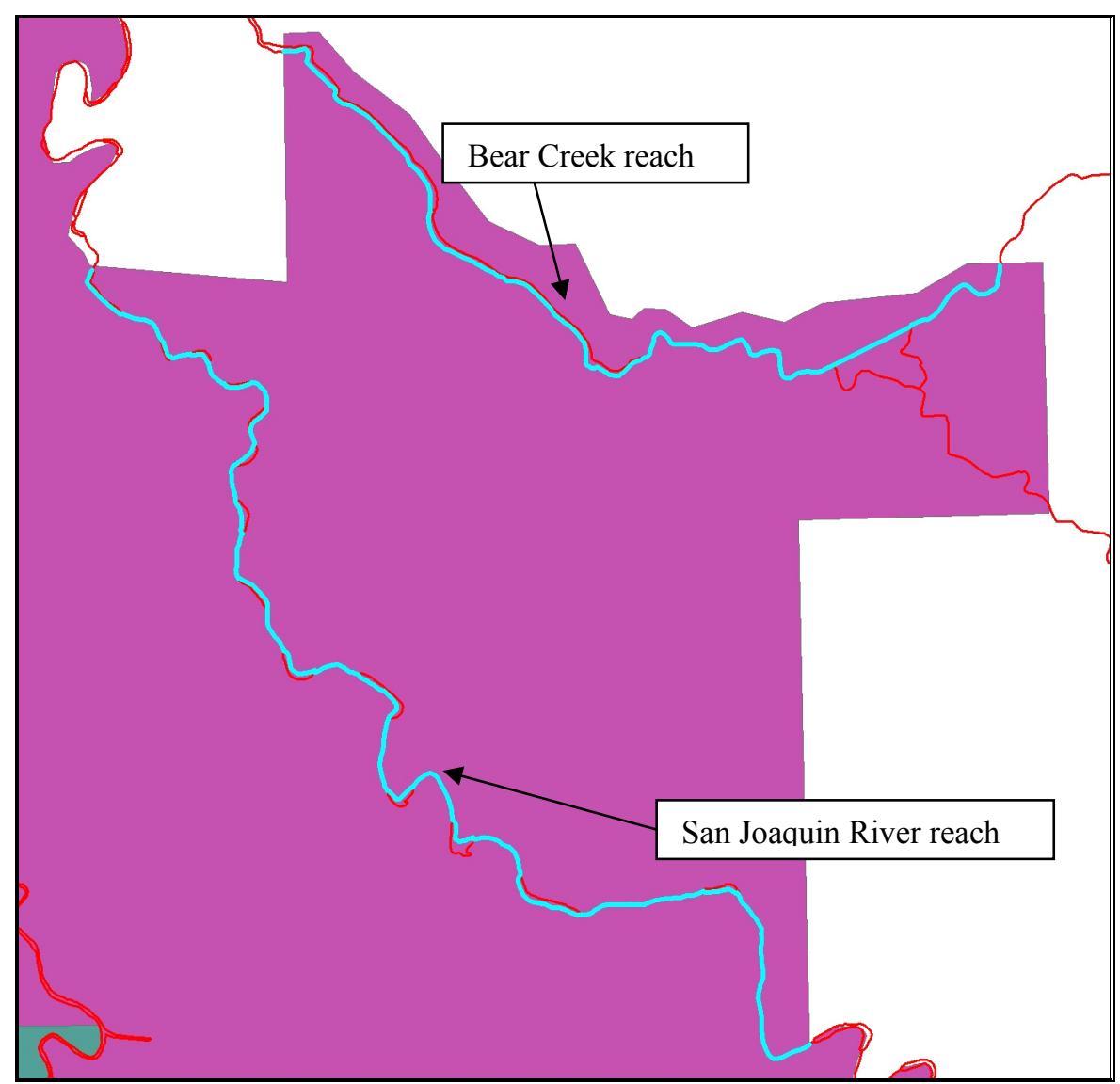

Figure 21. Arc lengths used in estimating potential shallow aquifer recharge to the East Bear Creek Unit from the San Joaquin River and Bear Creek. Upper arc is $6.476 \mathrm{~km}$ (4.1 mi) and the lower arc is $9.470 \mathrm{~km}(5.9 \mathrm{mi})$.

Although below-Corcoran pumping has been suggested by some groundwater hydrologists as a possible solution - there are no available data from wells developed within the sub-Corcoran aquifer to ascertain the merits of this proposal. From a long-term sustainability perspective - the presence of poor quality groundwater in the aquifer immediately above the Corcoran Clay aquitard would suggest that increased gradients might induce greater across-Corcoran flow, leading term long-term decline in water quality. The thickness of the Corcoran Clay in the vicinity of the Valley trough and the extremely low transmissivity of this aquitard suggest that this process would take decades to be have a significant impact.

\section{FINDINGS AND RECOMMENDATIONS}

Hydrogeological assessment of the East Bear Creek Unit was conducted using a combination of field investigations and a survey of previous aquifer investigations by US Bureau of Reclamation staff geologists. Safe yield estimates made using the available data show that the East Bear Creek Unit may have sufficient groundwater resources in the shallow groundwater aquifer to meet between $17 \%$ and $35 \%$ of current Level IV water supply needs. The rate of surface and lateral recharge to the Unit and the design of the well field and the layout and capacity of pumped wells will decide both the percentage of annual needs that the shallow aquifer can supply and whether this yield is sustainable without affecting long-term aquifer quality. 
In order to further investigate the merits of pumping the near surface aquifer, which appears to have reasonable water quality for use within the East Bear Creek Unit - monitoring of the potential sources of aquifer recharge and the installation of a pilot shallow well would be warranted. Simple monitoring stations could be installed both upstream and downstream of both the San Joaquin River and Bear Creek and be instrumented to measure river stage, flow and electrical conductivity. Ideally this would be done in conjunction with a shallow pilot well that was pumped to supply part of the Unit's needs for the duration of the wetland inundation period. 


\section{REFERENCES}

Brush, C.F., K. Belitz, S.P. Phillips, K.R. Burow and D.L. Knifong. 2005. MODGRASS: Update of a ground-water flow model for the central part of the western San Joaquin Valley, California

California Department of Water Resources. 2003. Bulletin 118: California's Groundwater, Update 2003, April 2003.

Cooper H.H. and C.E. Jacob. 1946. A Generalized Graphical Method for Evaluation Formation Constants and Summarizing Well Field History. Am. Geophys. Union Trans., Vol 27, pp 526-534.

Bookman-Edmonston, 2003. Hydrogeologic Assessment. Prepared for Stevinson Water District. December 2003. 30p.

Driscoll F.G. 1989. Groundwater and Wells. Second Edition. Johnson Filtration Systems, St. Paul, Minn.

GEI Consultants, 2004. Water Supply, Water Recycling and Storm Water management Evaluation. Prepared for Stevinson Ranch Development. 58p.

Moench A.F. 1993. Computation of Type Curves for Flow to Partially Penetrating Wells in Water table Aquifers. Ground Water. Vol. 31, No. 6, pp 966-971.

Neuman S.P. 1975. Analysis of Pumping Well Data from Anisotropic Unconfined Aquifers Considering Delayed Yield. Water Resources Research. Vol. 11, No. 2, pp 329-342.

Quinn, N.W.T. 2006. Hydrogeologic Assessment of the 4-S Land and Cattle Company Ranch, April 10, 2006. Lawrence Berkeley National Laboratory. Paper LBNL-60011; U.S. Bureau of Reclamation, MP-400. http://repositories.cdlib.org/lbnl/LBNL-60011/

Schmidt K.D. 2005. Kenneth D. Schmidt and Associates. Groundwater Conditions in the Stevinson Area. Prepared for Bates Properties, Inc., Monterey, California. August 2005. $46 \mathrm{p}+$ appendices.

Su, G.W., N.W.T. Quinn, P.J. Cook, and W. Shipp. 2006. Miniaturization of the flowing fluid electrical conductivity logging technique, Ground Water, Vol. 44, No.5 pp. 754-757, Sept-Oct, 2006. LBNL59032.

Theis C.V. 1935. The Relation Between Lowering of the Piezometric Surface and the Rate and Duration of Discharge of a Well Using Groundwater Storage. Am. Geophys. Union Trans. Vol 16, pp 519-524.

U.S. Bureau of Reclamation. 2003. Memorandum to the Technical Files. Addendum to East Bear Creek Design Data Report, Central Valley Project, CA. Author : Steven G. Sherer, Regional Geology Section, Sacramento, CA.

U.S. Bureau of Reclamation. 2004. Memorandum to the Technical Files. Aquifer testing at proposed pumping plants of the re-aligned water supply pipeline for the East Bear Creek Unit of the San Luis NWR - Central Valley Project, CA. Author : William G. Shipp, Regional Geology Section, Sacramento, CA.

U.S. Geological Survey. 1971a. Data for Wells in the Modesto-Merced Area San Joaquin Valley, California. Prepared in cooperation with the California Department of Water Resources. Open-File Report. Menlo Park, California.

U.S. Geological Survey. 1971b. Geology, Hydrology, and Water Quality of the Tracy-Dos Palos Area, San Joaquin Valley, California. Prepared in cooperation with the California Department of Water Resources. Open-File Report. Menlo Park, California.

U.S. Geological Survey. 1973. Base of Fresh Ground Water (Approximately 3,000 Micromhos) in the San Joaquin Valley, California. Hydrologic Investigations, Atlas HA-489. Prepared in cooperation with the California Department of Water Resources. Washington D.C.

U.S. Geological Survey. 1986. Geology of the Fresh Ground-Water Basin of the Central Valley, California, with Texture Maps and Sections: Regional Aquifer-System Analysis. U.S. Geological Survey Professional Paper 1401-C. 
US Geological Survey. 1983. Groundwater Conditions and Shallow test-Well Information in the Eastern Half of Merced County, California, 1977-82. Prepared in Cooperation with the City of Merced. Water Resources Investigations, report 83-4081.

U.S. Geological Survey. 1989. Ground-Water Flow in the Central Valley, California: Regional AquiferSystem Analysis. U.S. Geological Survey Professional Paper 140 1-D

U.S. Geological Survey. 1989. Study and Interpretation of the Chemical Characteristics of Natural Water, Third Edition. U.S. Geological Survey Water-Supply Paper 2254.

U.S. Geological Survey. 1991. Ground Water in the Central Valley, California-A Summary Report: Regional Aquifer-System Analysis. U.S. Geological Survey Professional Paper 1401 -A.

Waterloo Hydrogeologic. 2000. AquiferTest User's Manual. Intuitive Analysis and Reporting of Pumping Test and Slug test Data. Waterloo, Canada. 


\begin{abstract}
APPENDIX A
Pumping test results from test wells in the East Bear Creek Unit. Tests conducted by
\end{abstract} Shipp and Sherer (US Bureau of Reclamation, 2003) 


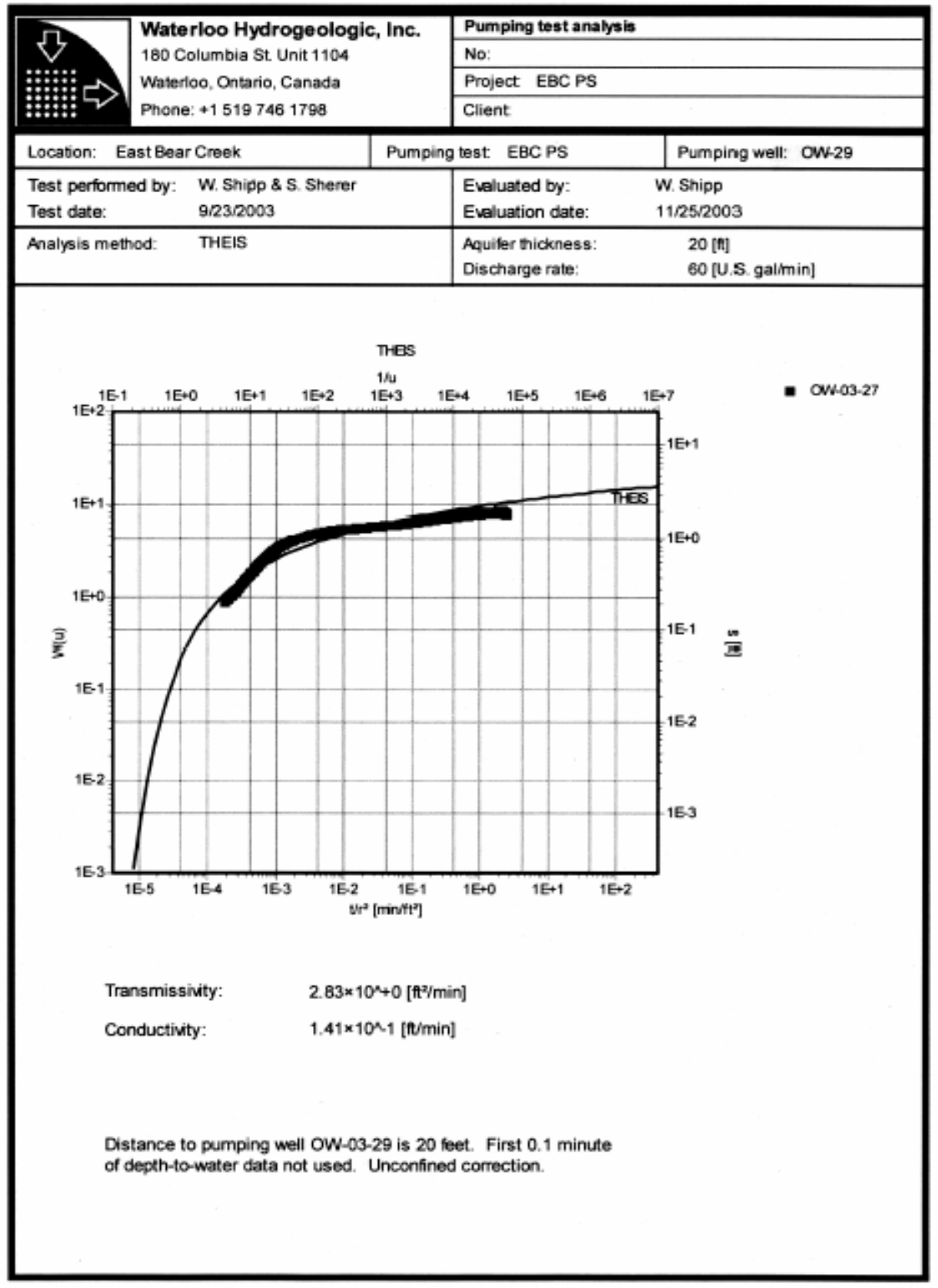

Figure A1. Theis analysis from pump test data from observation well OW-03-27 during pumping test at well OW-29 


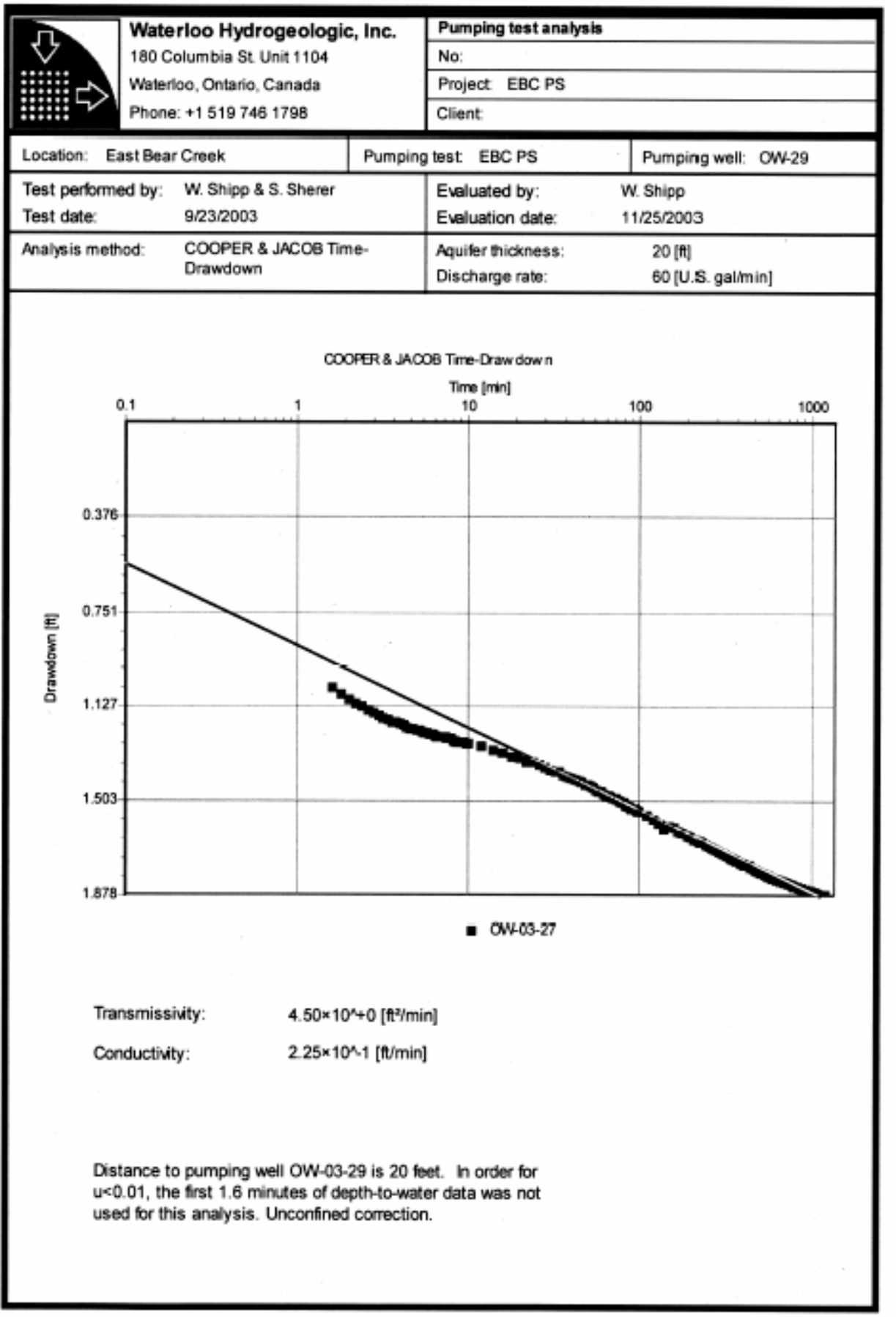

Figure A2. Cooper and Jacob analysis from pump test data from observation well OW-03-27 during pumping test at well OW-29 


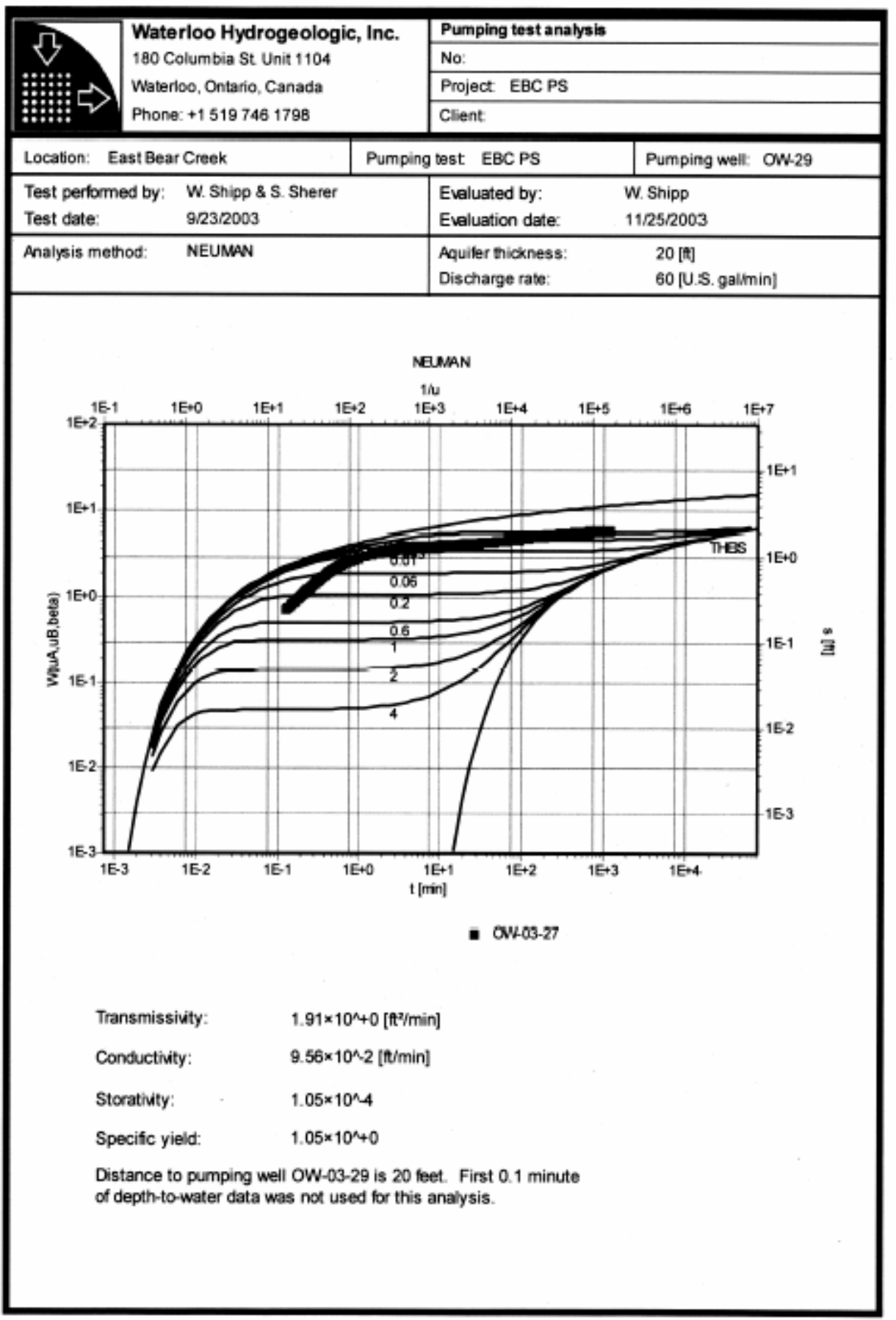

Figure A3. Neuman analysis from pump test data from observation well OW-03-27 during pumping test at well OW-29 


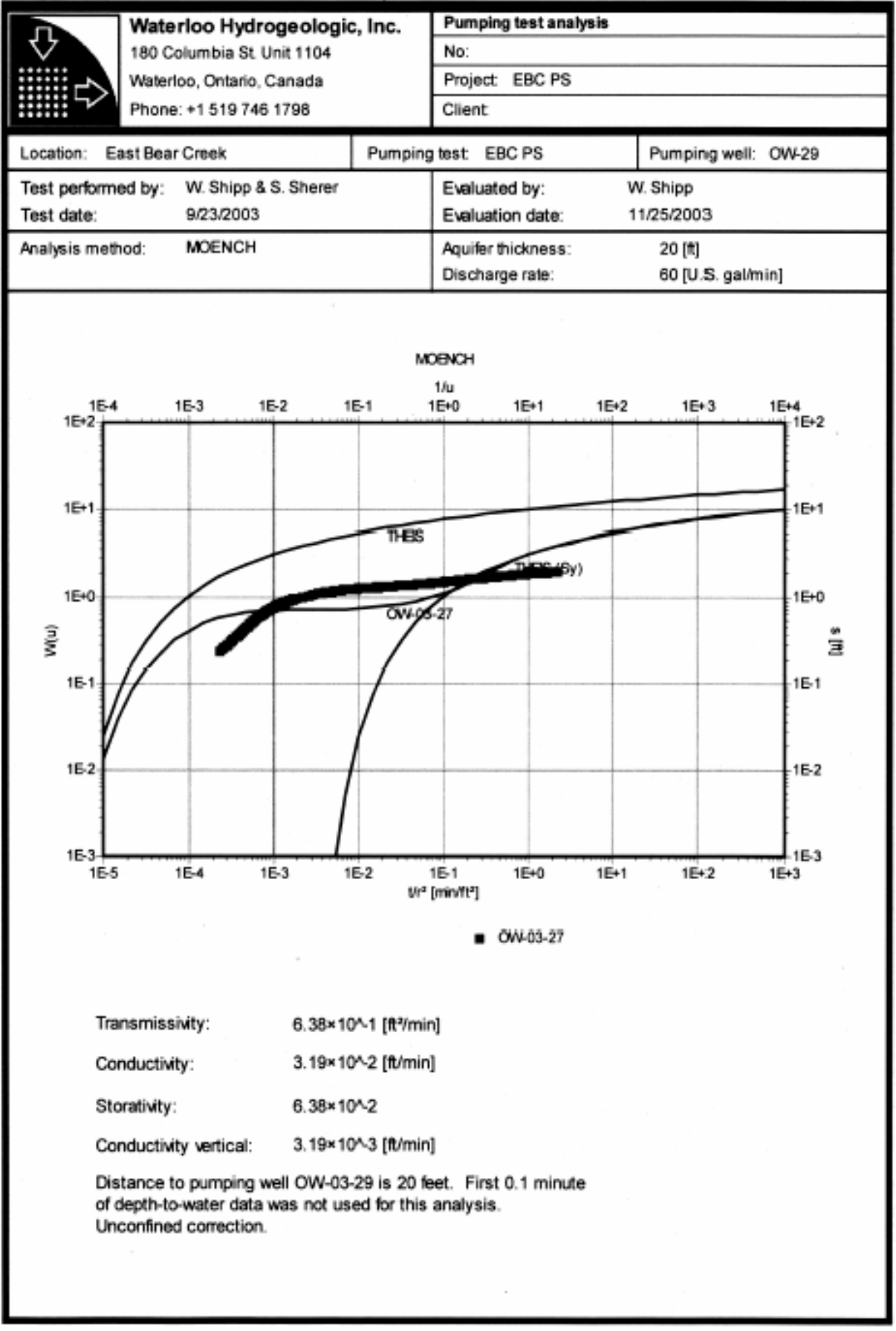

Figure A4. Moench analysis from pump test data from observation well OW-03-27 during pumping test at well OW-29 


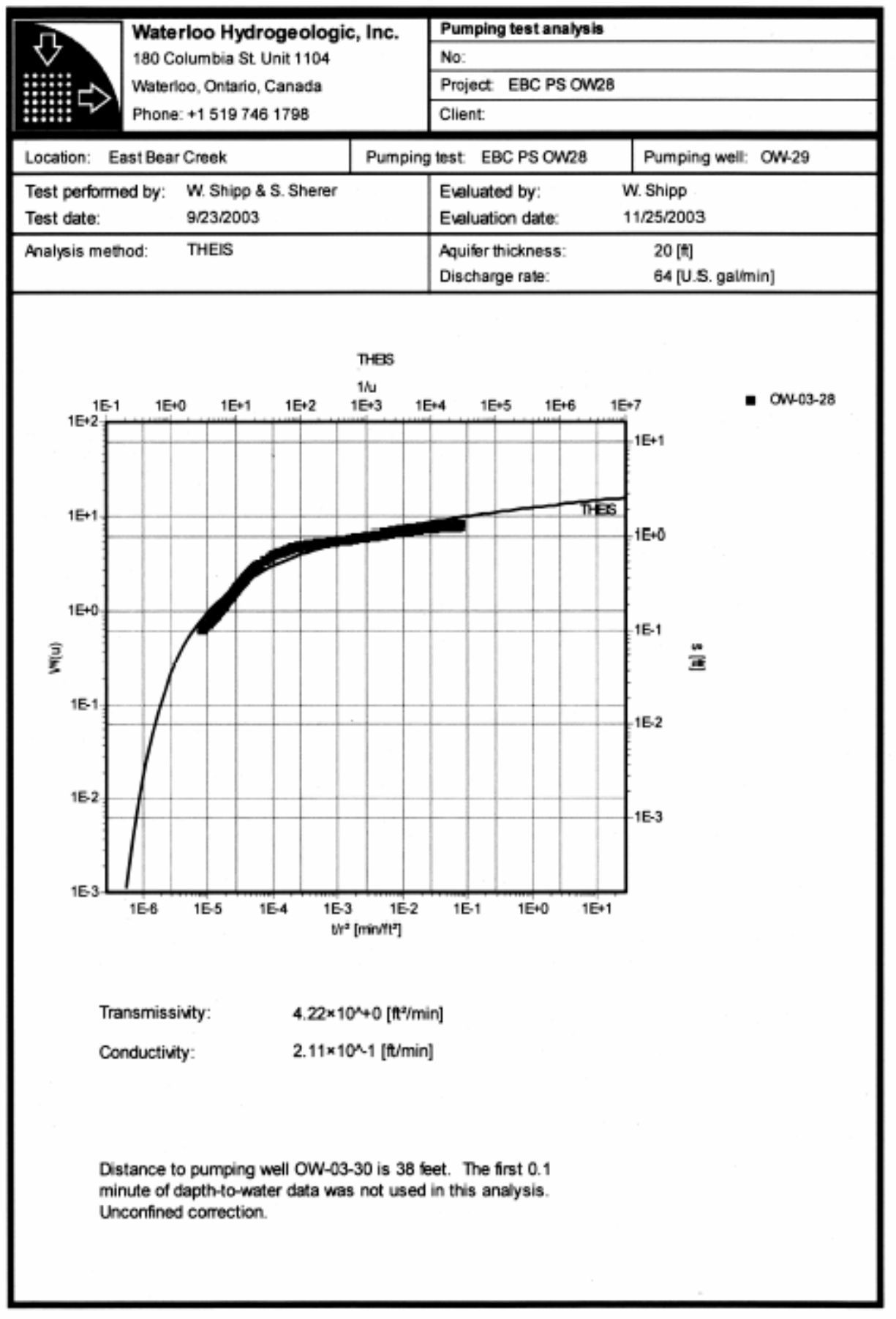

Figure A5. Theis analysis from pump test data from observation well OW-03-28 during pumping test at well OW-29 


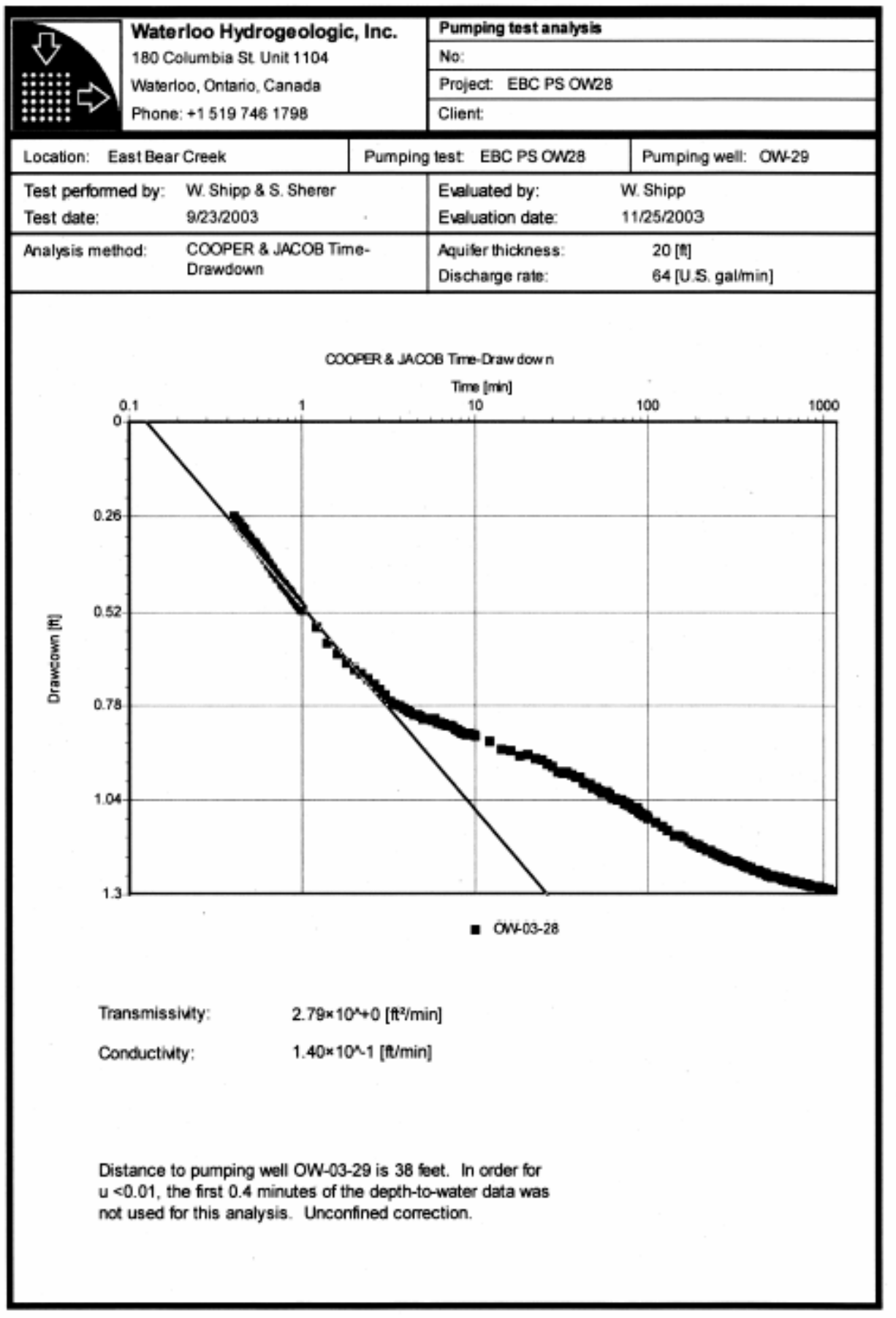

Figure A6. Cooper and Jacob analysis from pump test data from observation well OW-03-28 during pumping test at well OW-29 


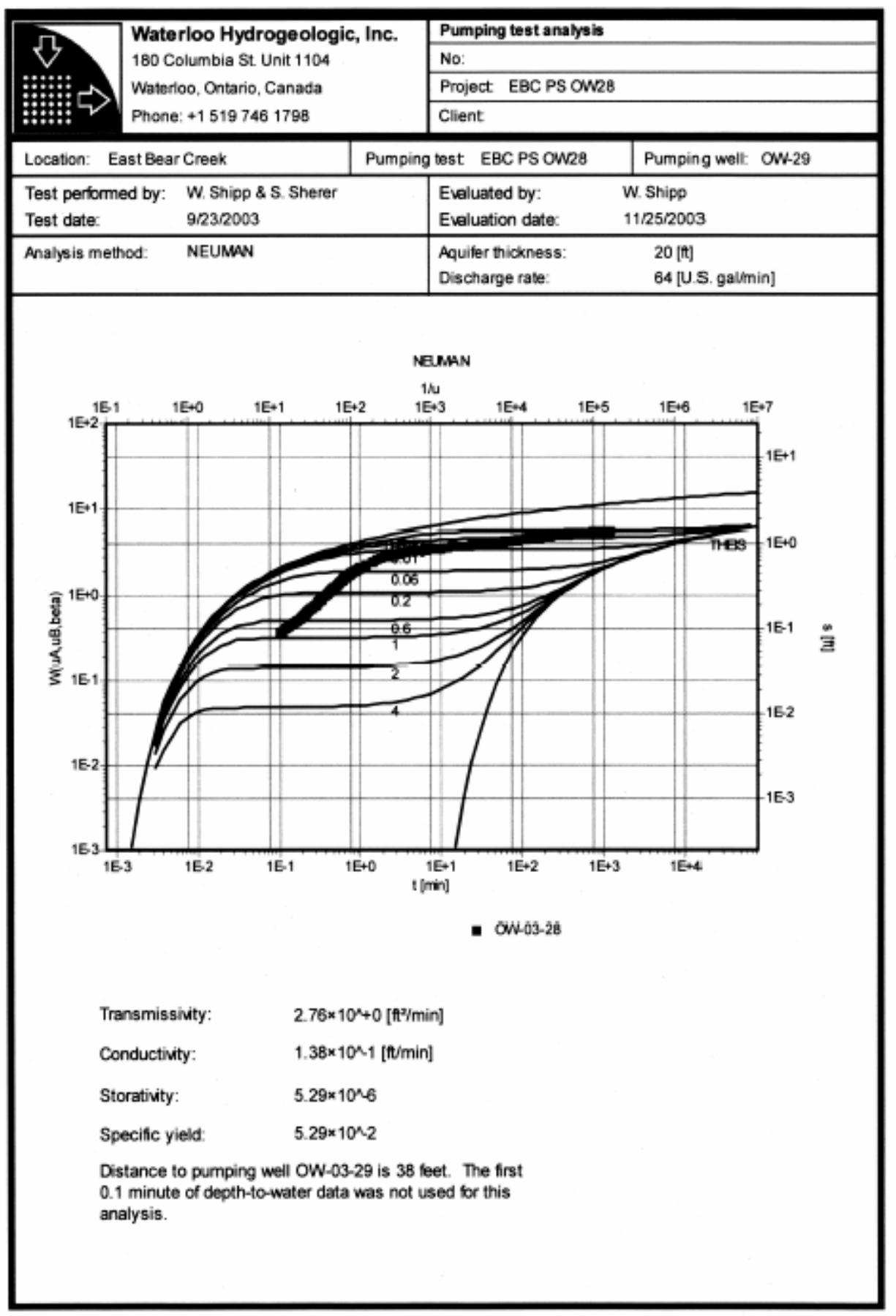

Figure A7. Neuman analysis from pump test data from observation well OW-03-28 during pumping test at well OW-29 


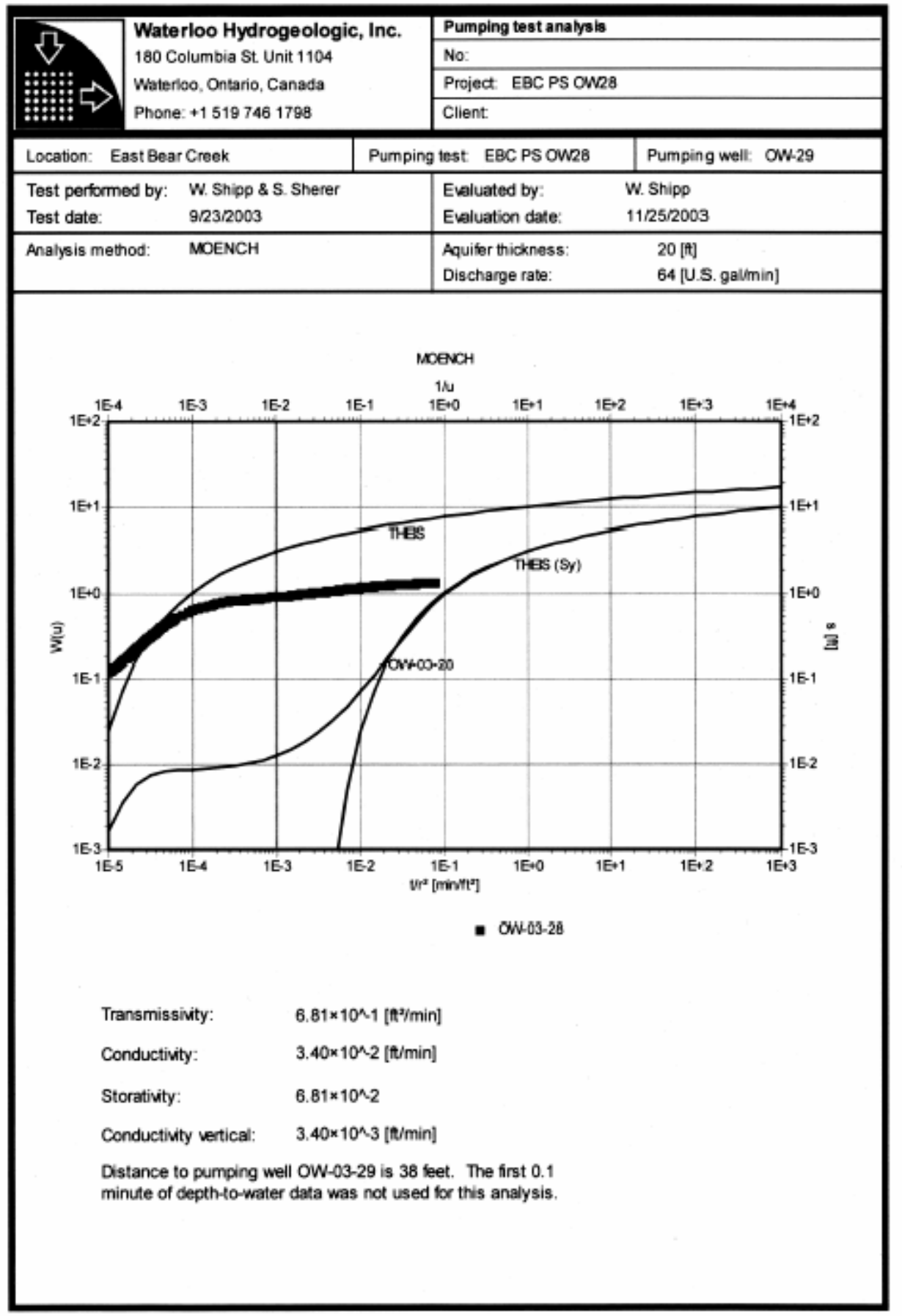

Figure A8. Moench analysis from pump test data from observation well OW-03-28 during pumping test at well OW-29 


\section{APPENDIX B}

Geologic Logs from test holes (from Sherer, 2003). 


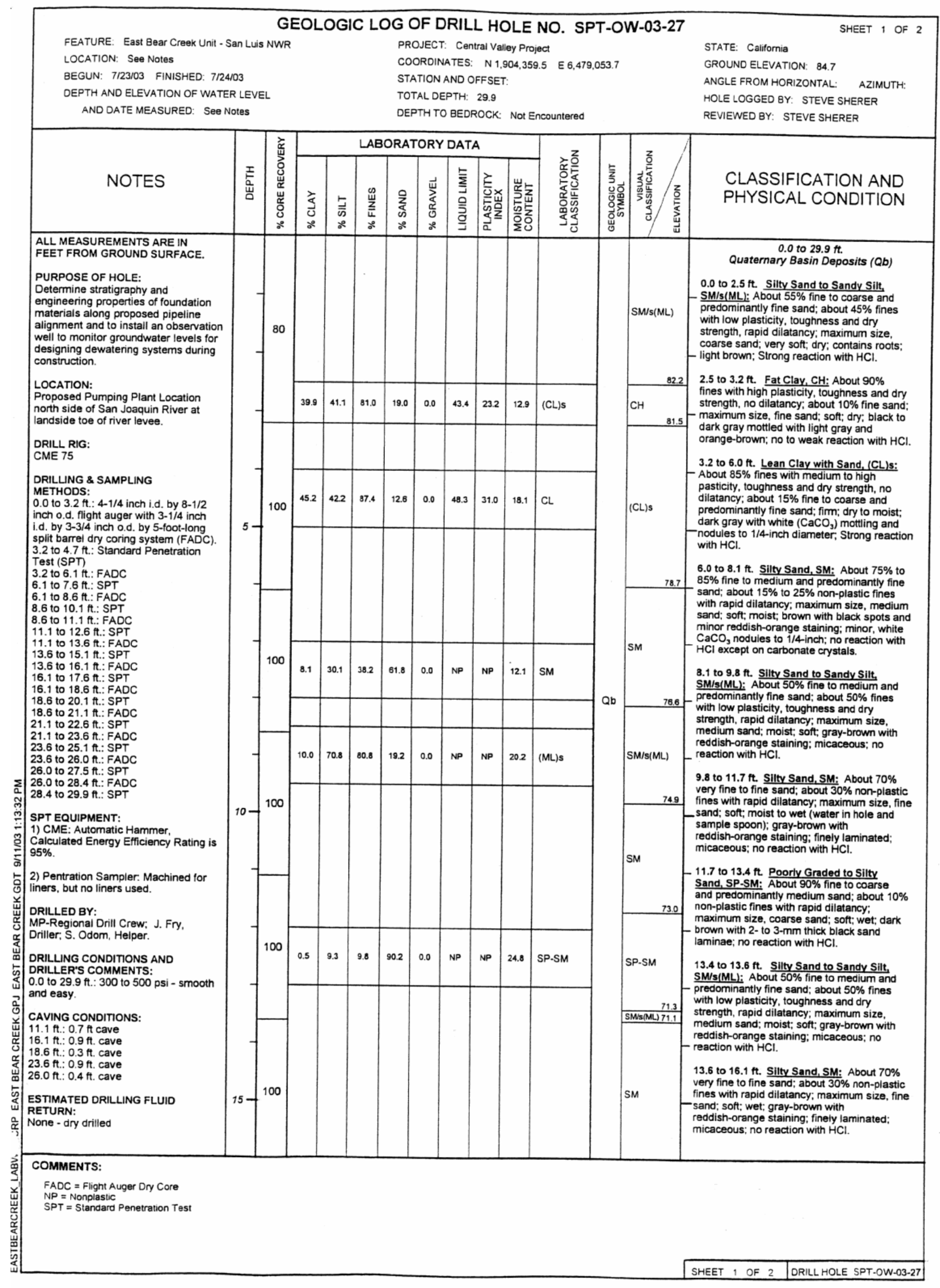




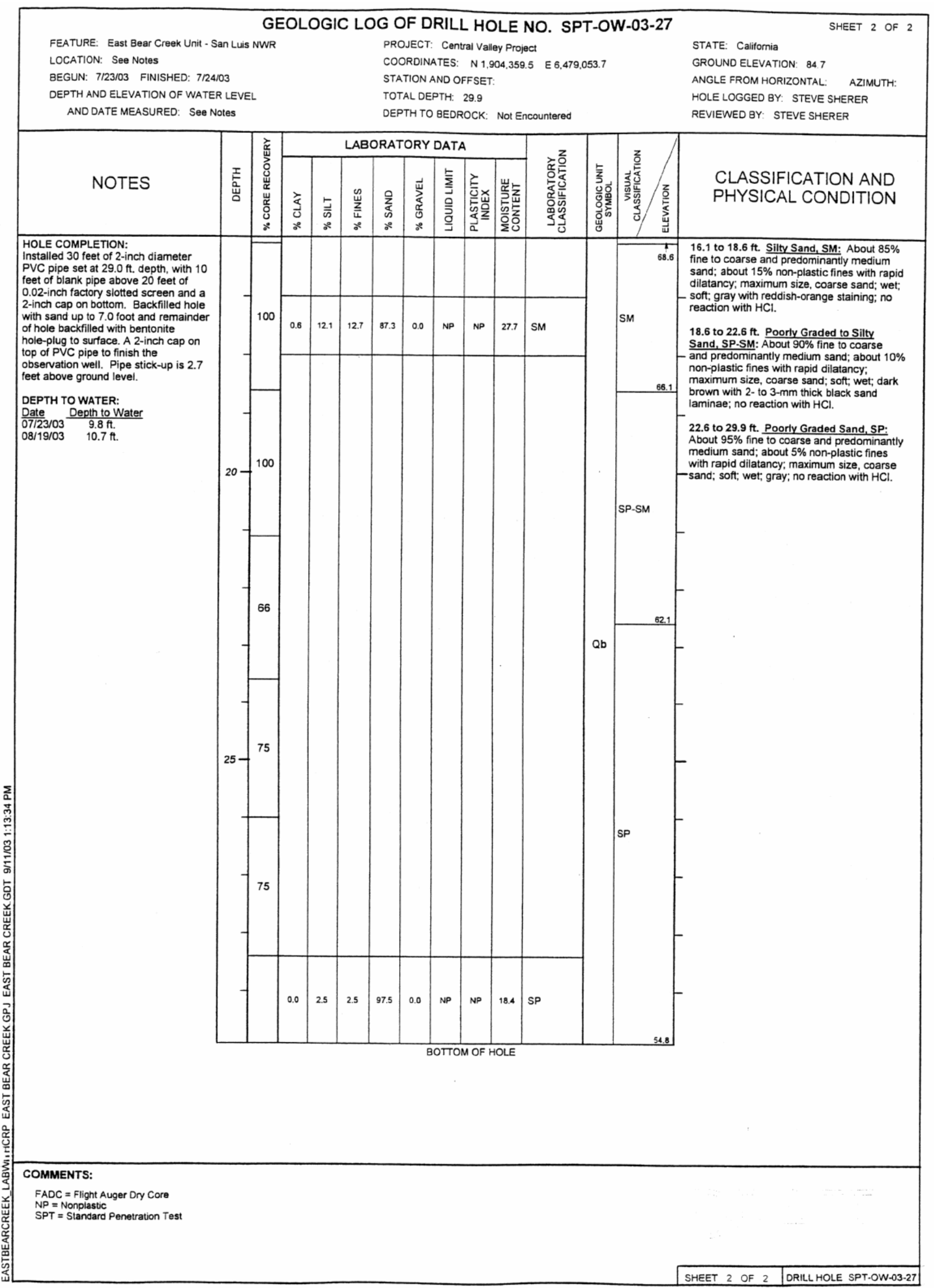




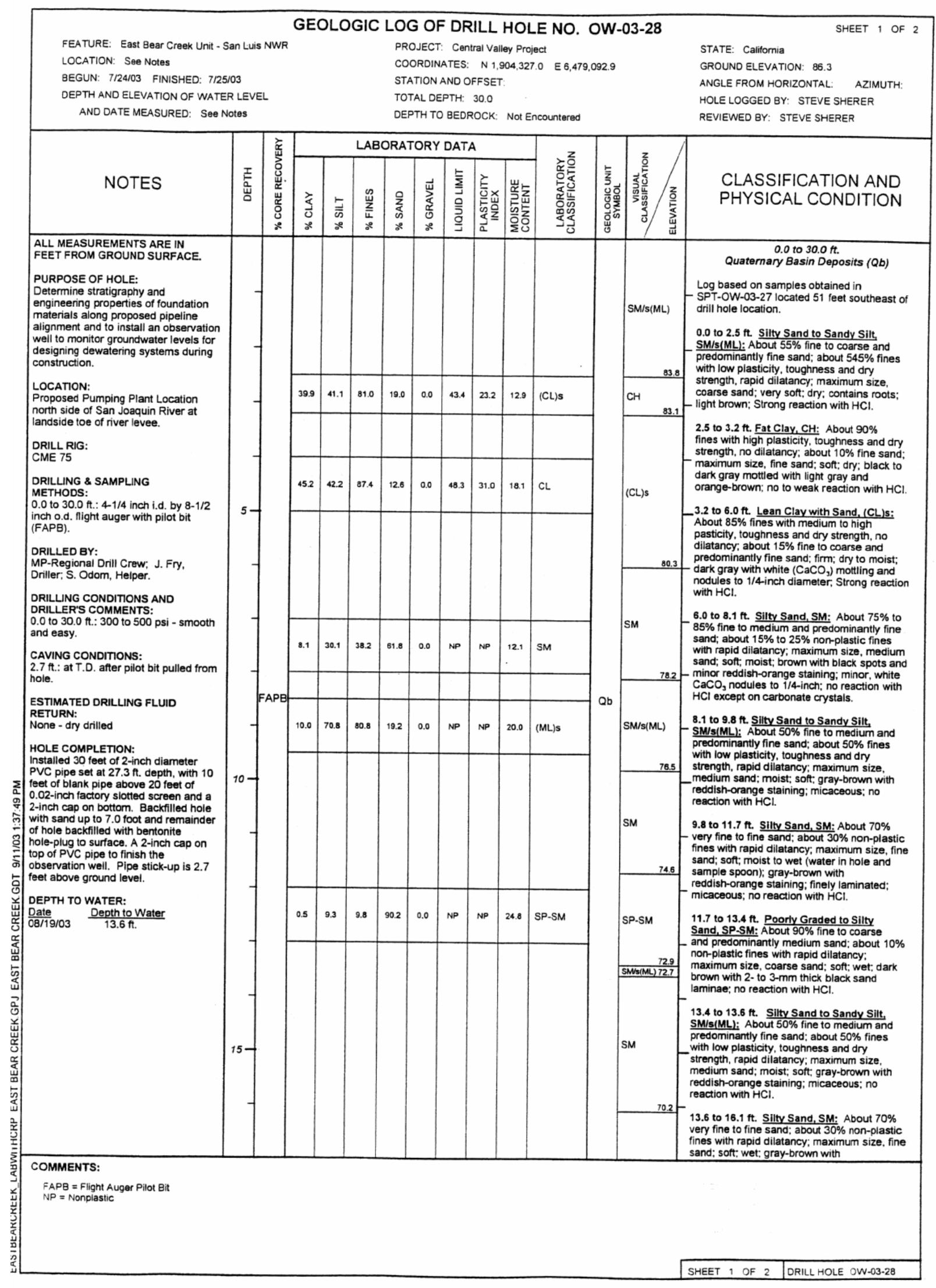




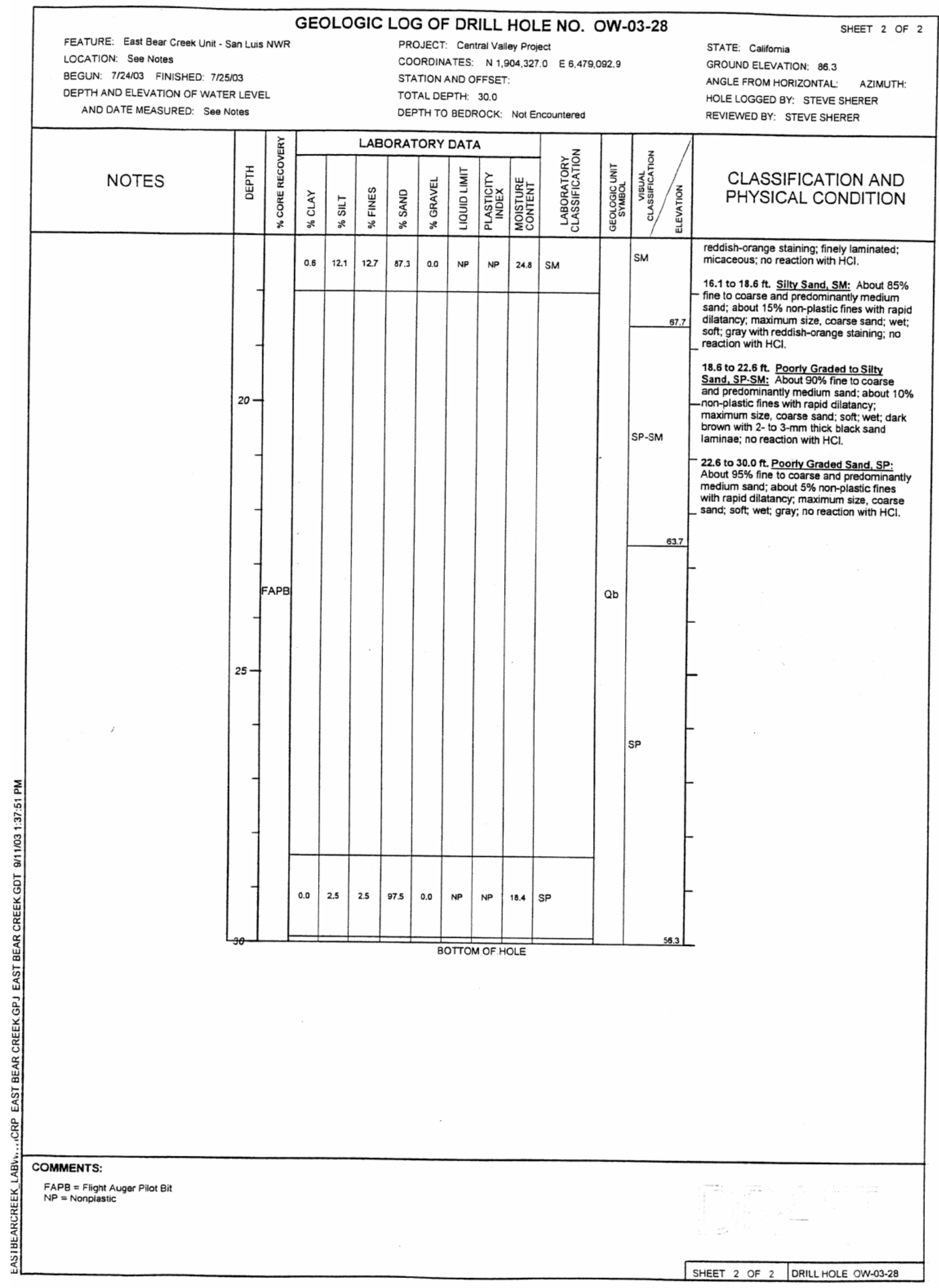




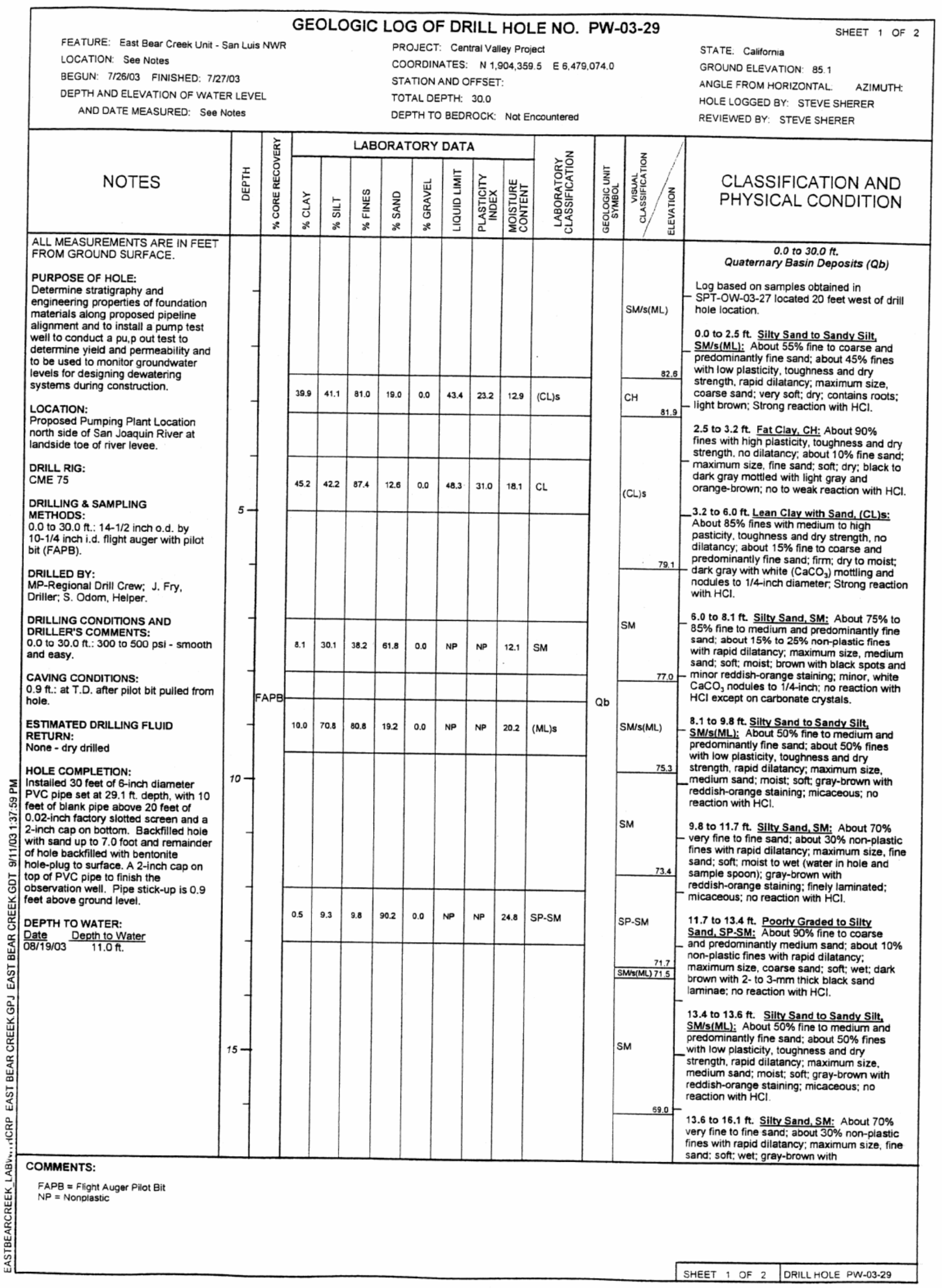




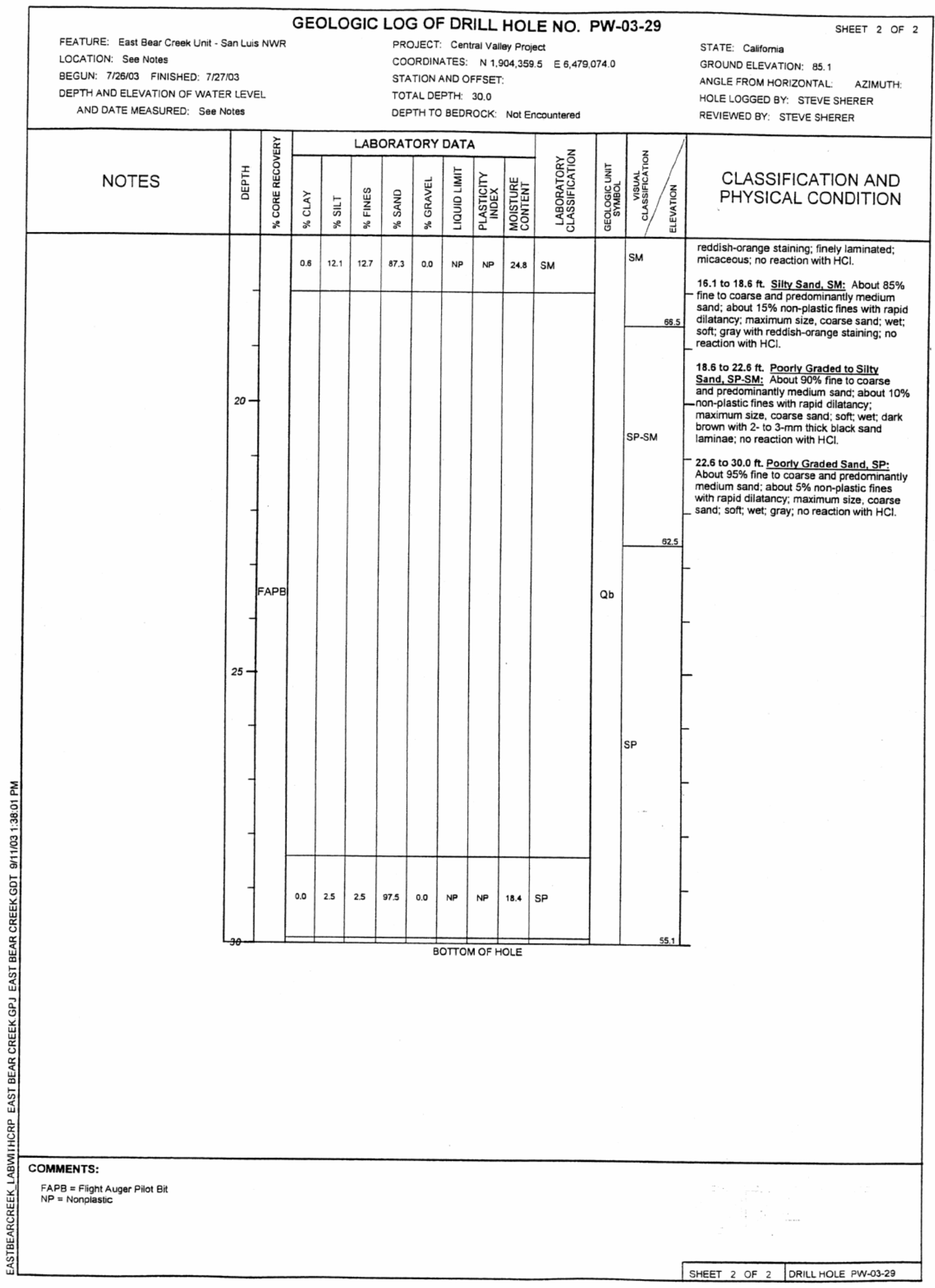




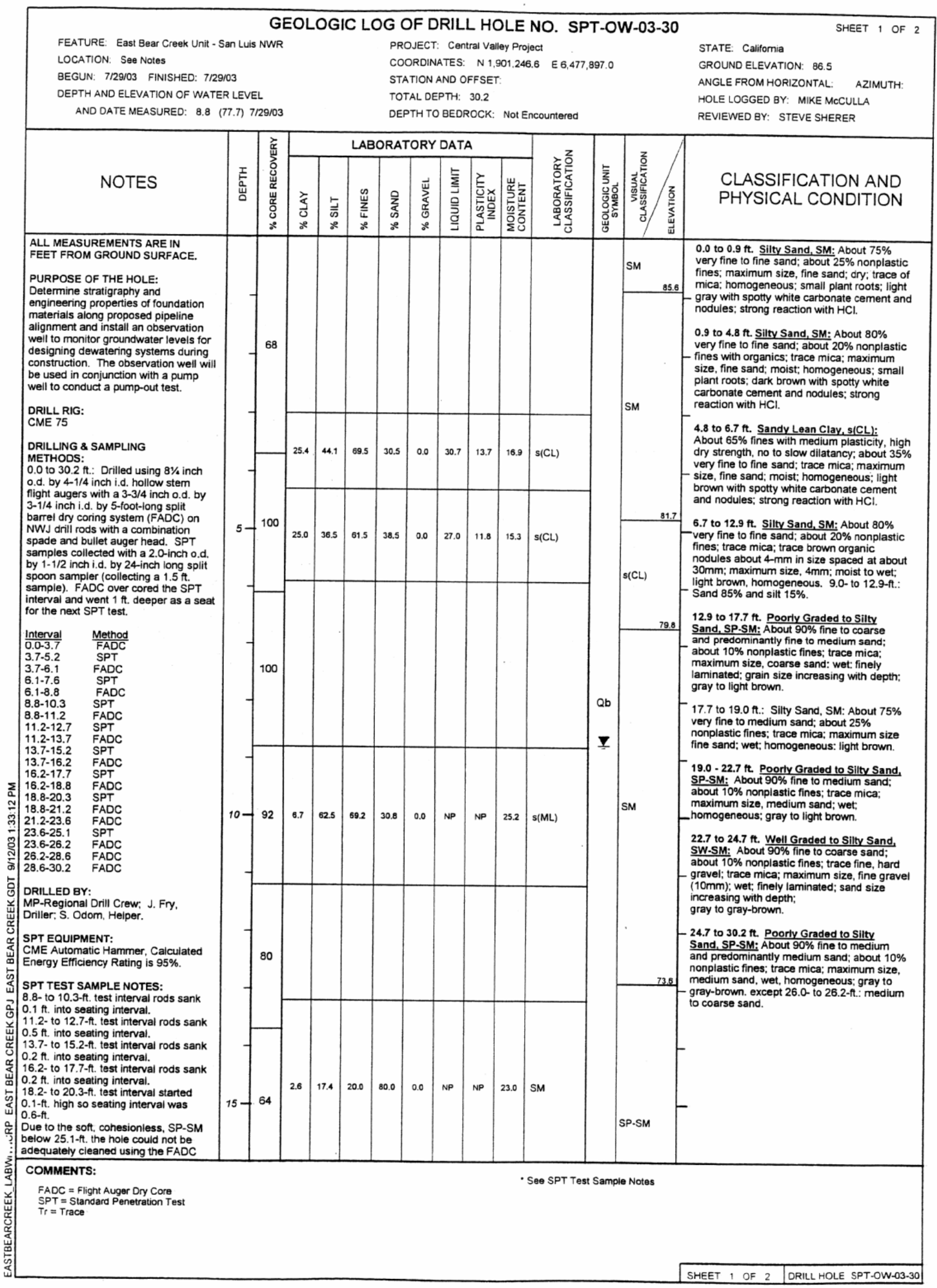




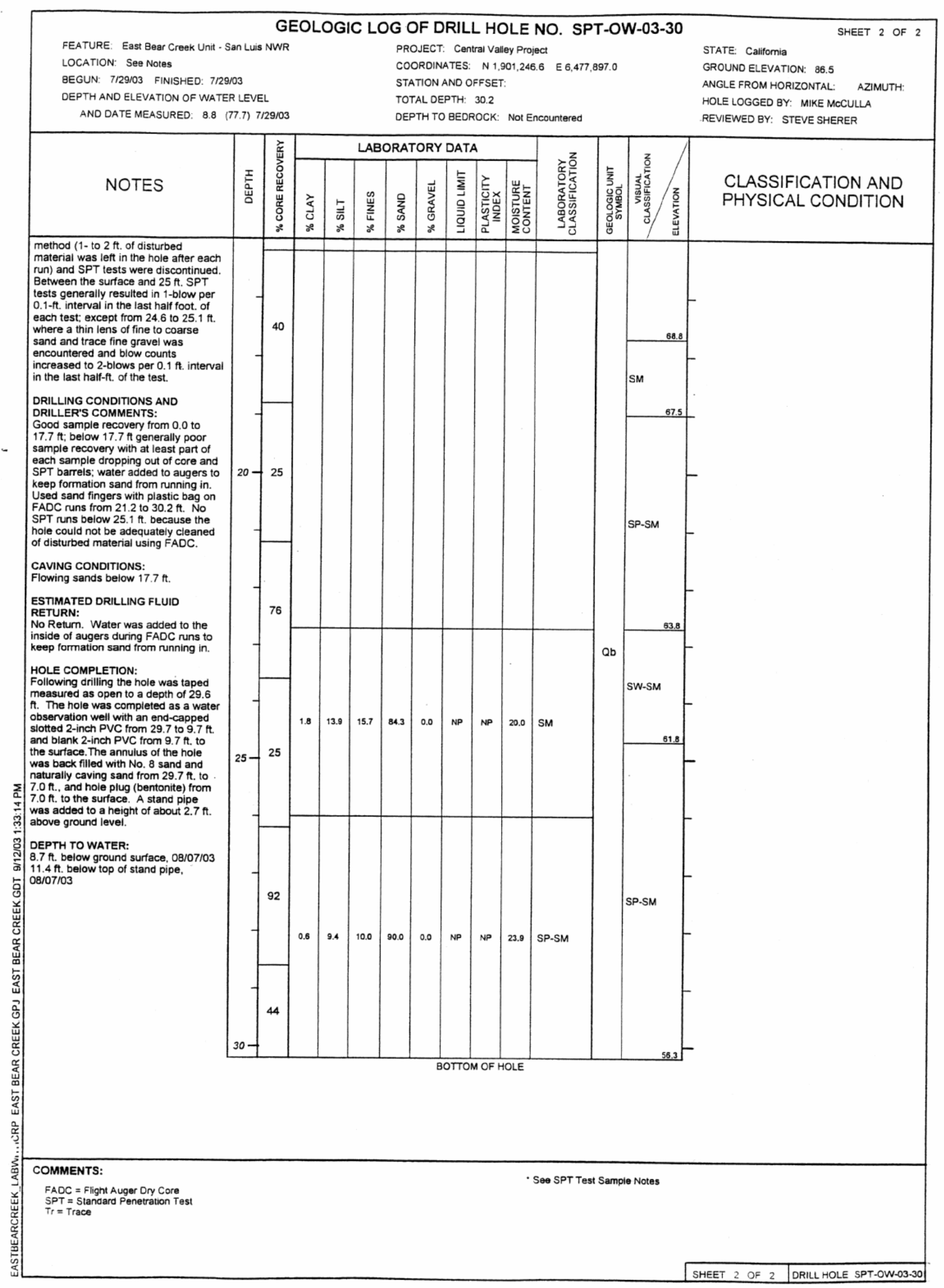




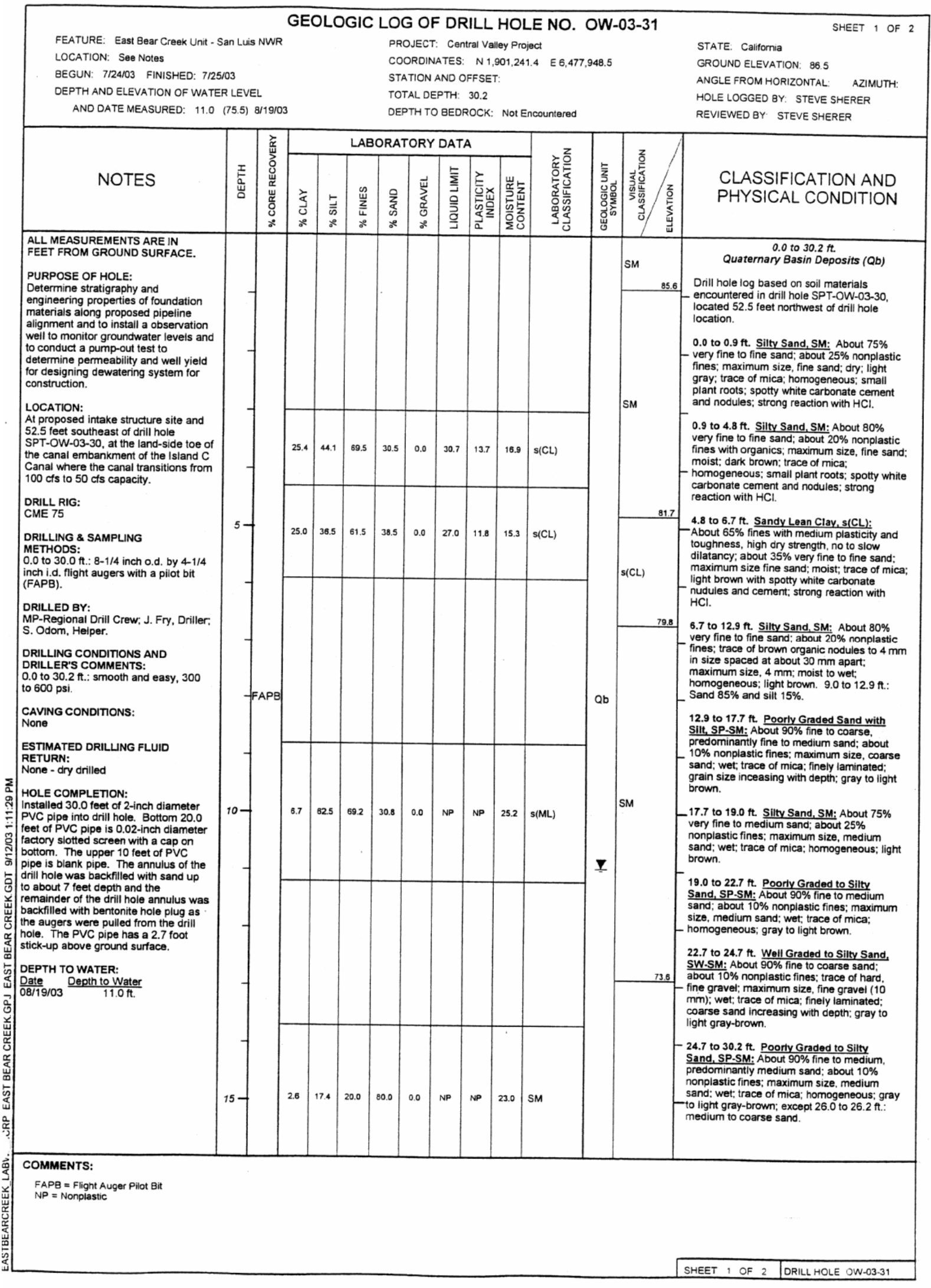




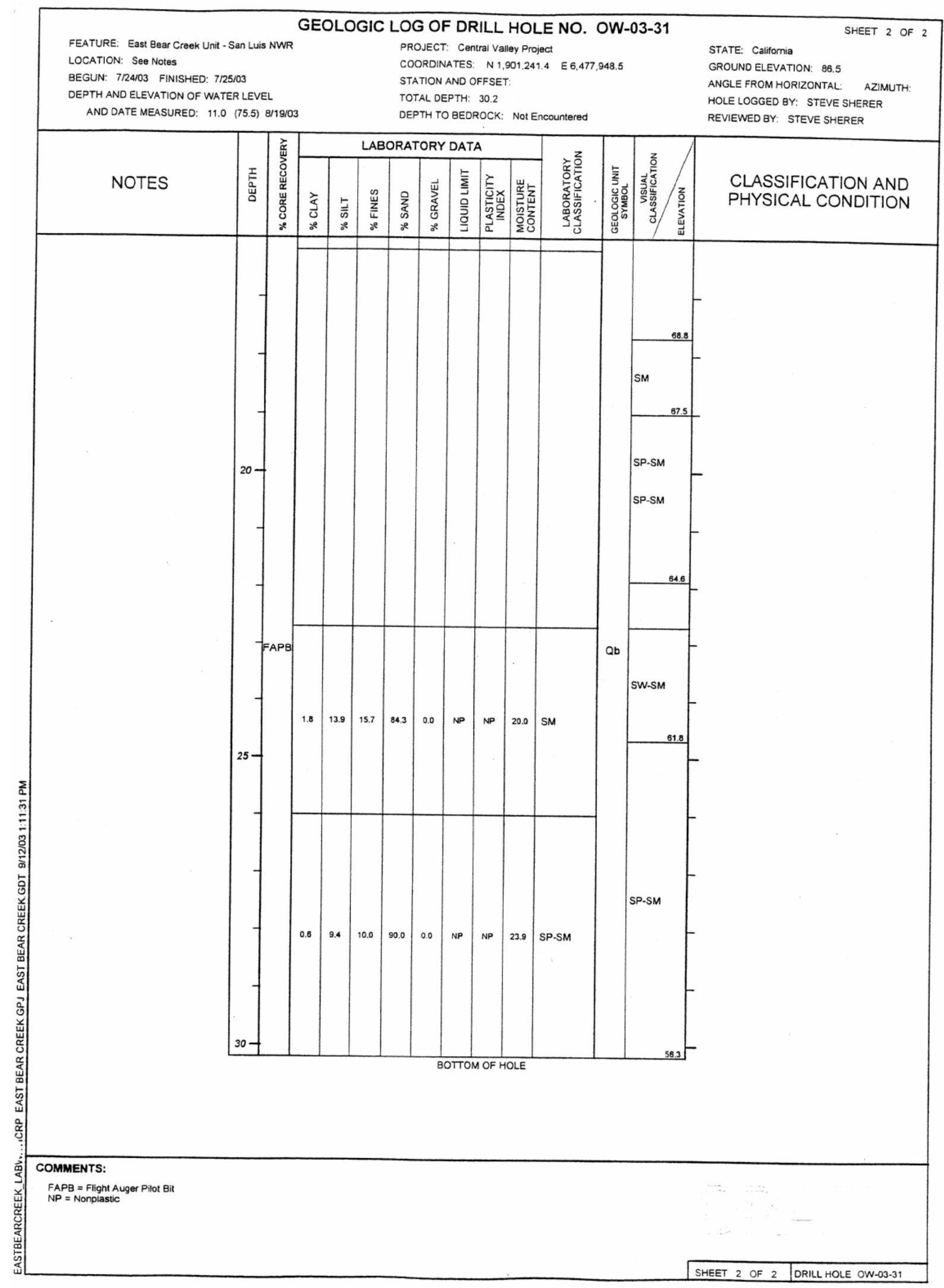




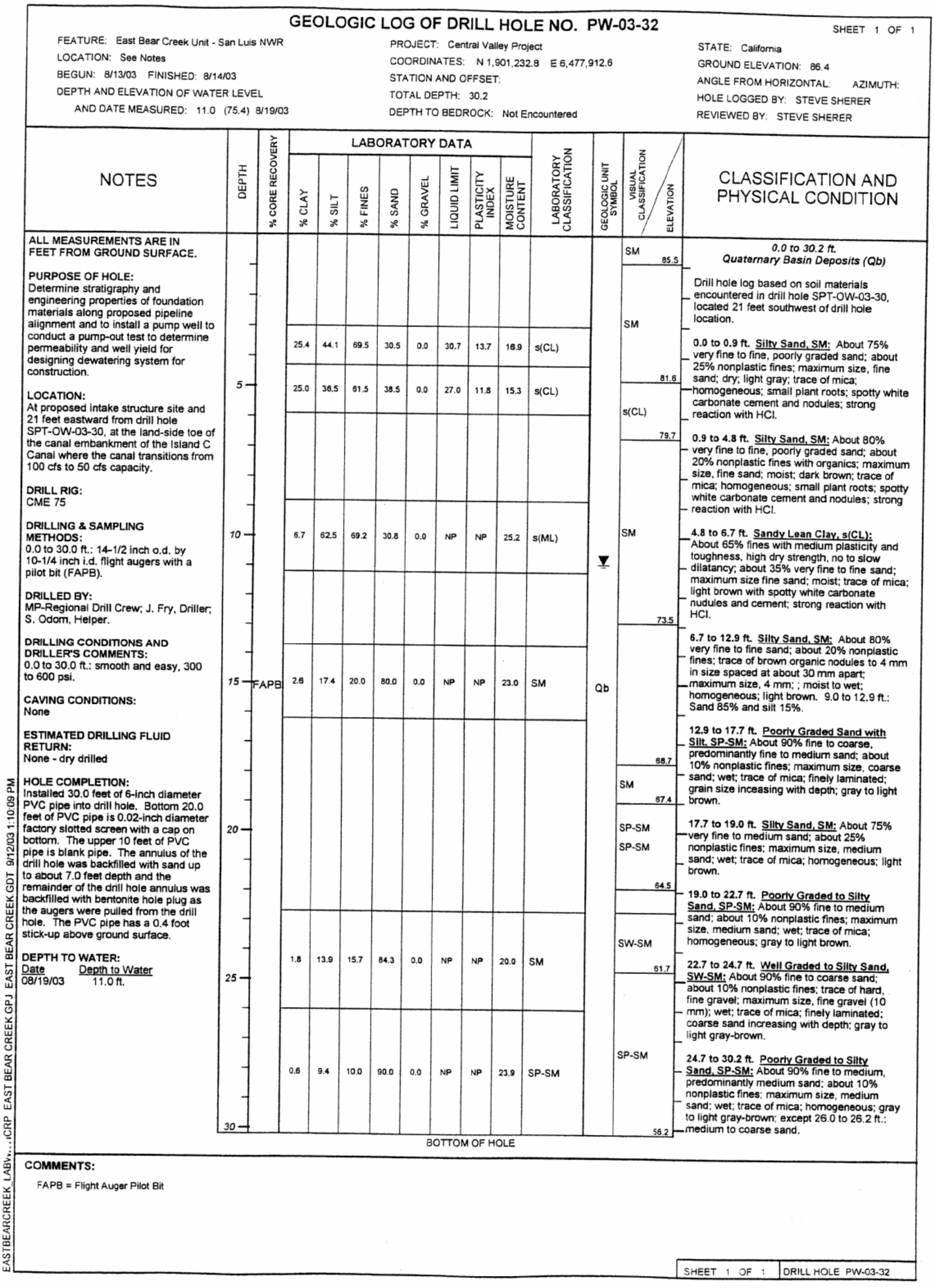




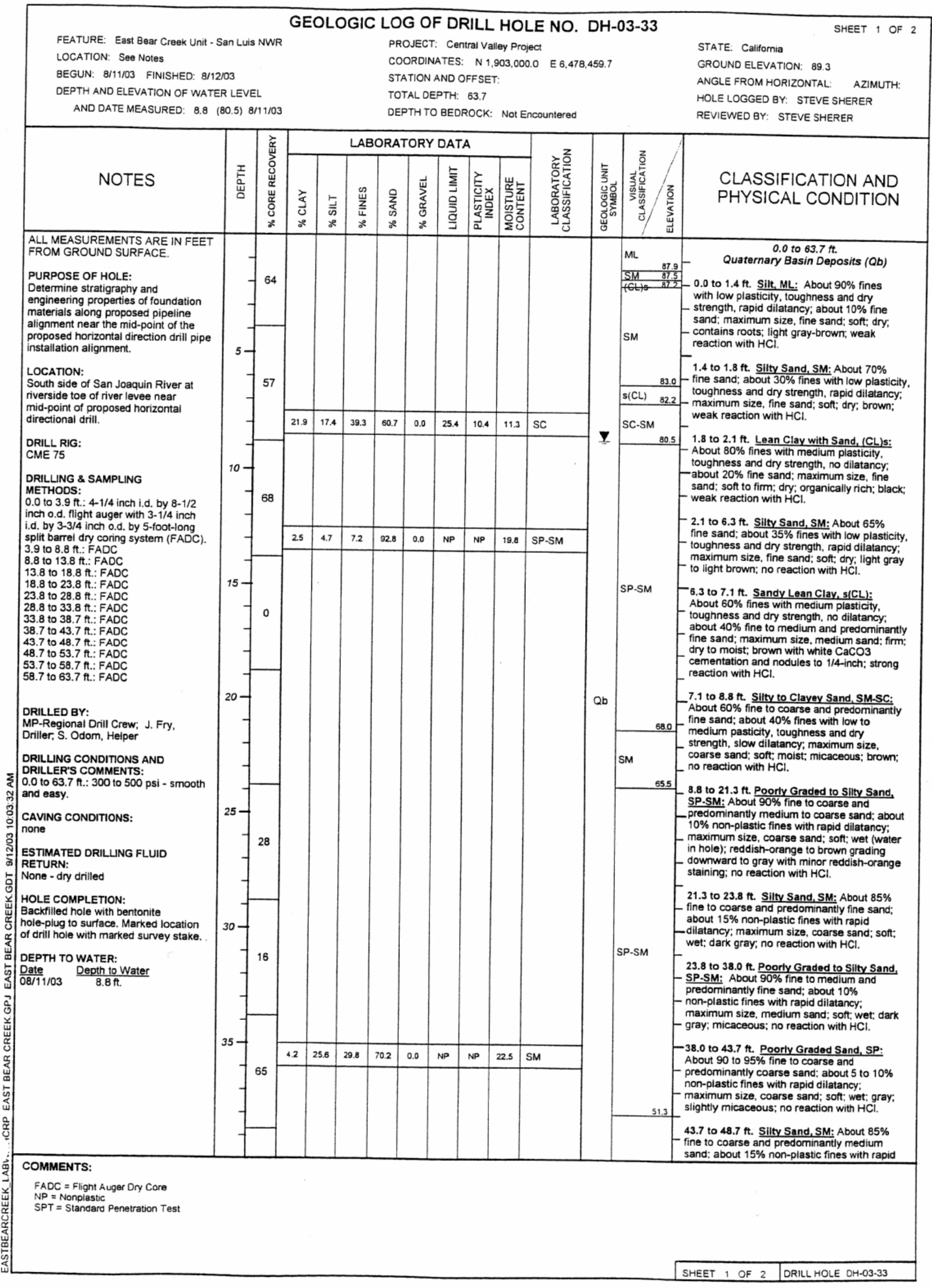




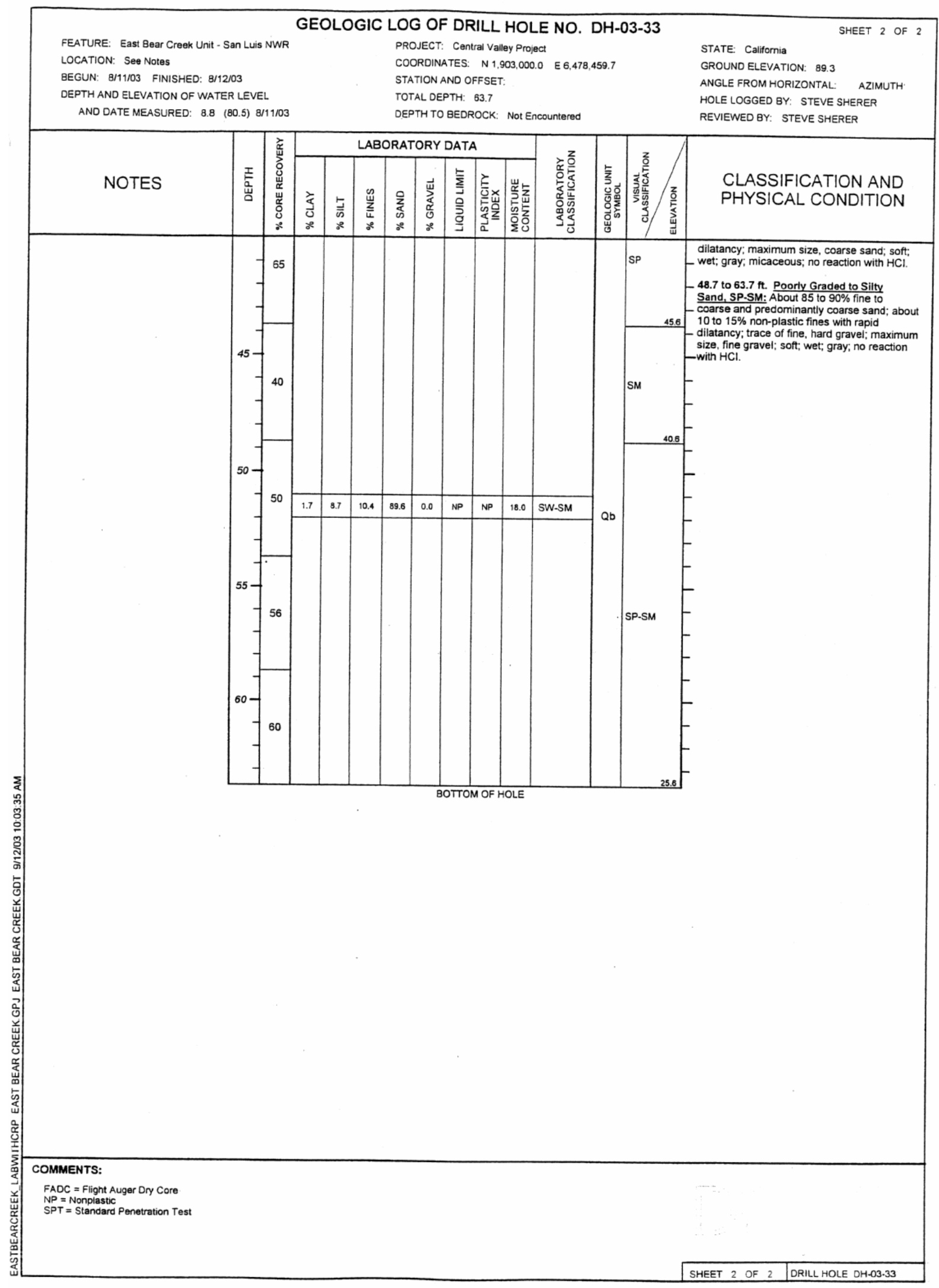


APPENDIX C

East Bear Creek Refuge Water Supply 


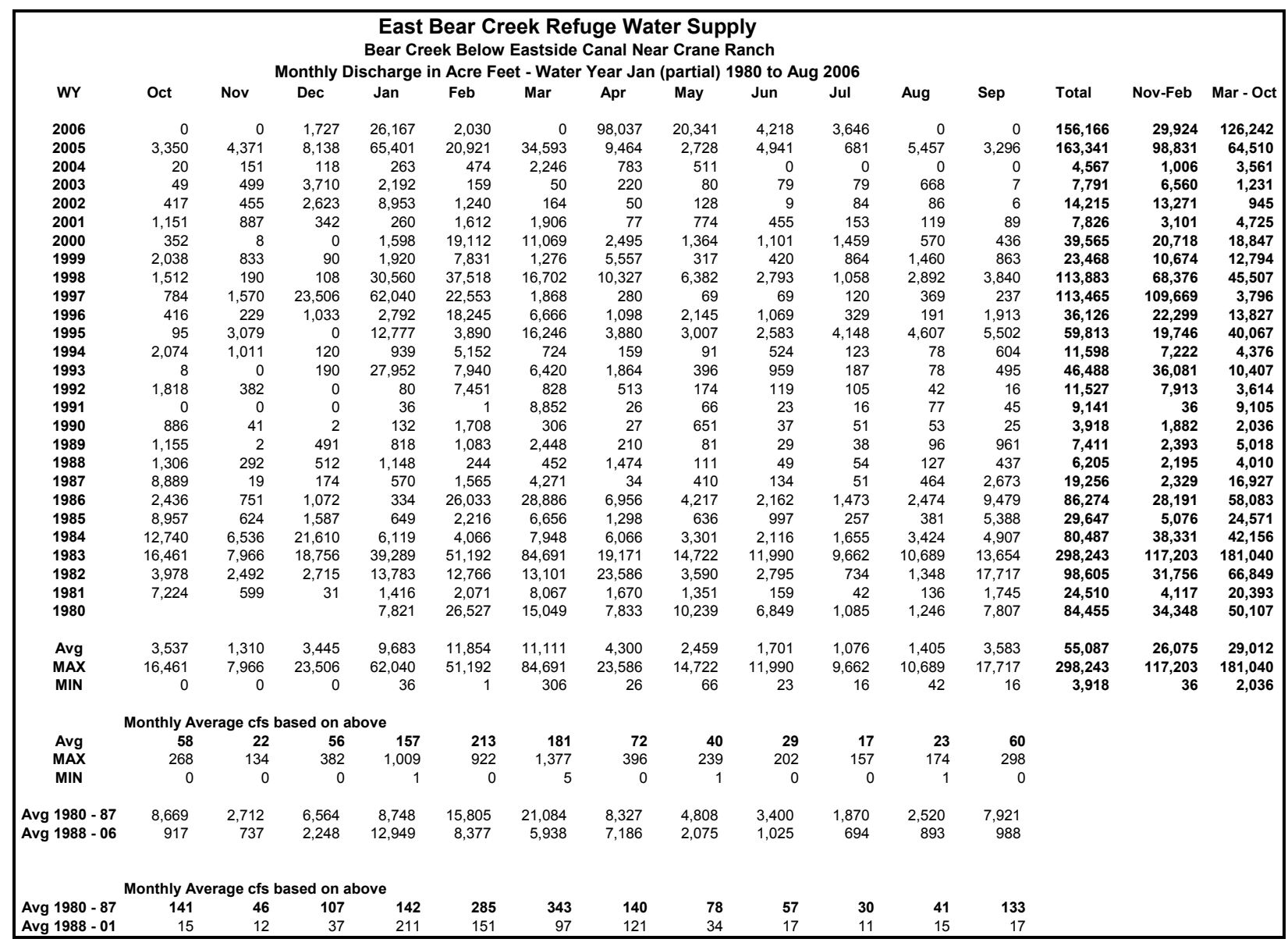


